\title{
2DE-FC36-03G013101
}

\section{Development of Polybenzimidazole-Based \\ High-Temperature Membrane and Electrode Assemblies for Stationary and Automotive Applications}

Final Report - August 2008

Prepared for:

U.S. Department of Energy

Technology Development Manager: Kathi Epping

Project Officer: David Peterson

Technical Advisor: John Kopasz

Prepared by:

Plug Power Inc., Albany, NY John Vogel, Project Manager 


\section{TABLE OF CONTENTS}

Table of Contents

EXECUTIVE SUMMARY

Background

Objectives

Technical Approach

Technical Achievements

Accomplishments and Innovations

\section{FOCUS 1 RESULTS:}

POLYMER AND MEMBRANE SCREENING AND FABRICATION

Task 1: Polymer and Membrane Screening and Preliminary Evaluation

Task 2: Detailed Polymer Characterization

Task 3: Low-Cost Membrane Formation Techniques

Task 4: Membrane Scale-up

\section{FOCUS 2 RESULTS:}

MEA CHARACTERIZATION

Task 5: 10- and 43-cm2 MEA Screening

Task 6: 45-cm2 MEA Evaluation

Task 7: 440-cm2 MEA Test in Short Stack

Task 8: Long-Term MEA Performance Characterization

FOCUS 3 RESULTS:

HARDWARE DEVELOPMENT AND DEMONSTRATION

Task 9: Acid Management

Task 10: PBI-Specific Flow Field Design

Task 11: Electrode Development and Performance Improvement

Task 12: Cost Assessment

\section{CONCLUSIONS}

\section{PROGRAM-RELATED PATENTS AND PUBLICATIONS}




\section{EXECUTIVE SUMMARY}

\section{Background}

The program began on August 1, 2003 and ended on July 31, 2007.

The goal of the project was to optimize a high-temperature polybenzimidazole (PBI) membrane to meet the performance, durability, and cost targets required for stationary fuel cell applications. These targets were identified in the Fuel Cell section (3.4) of DOE's Hydrogen, Fuel Cells and Infrastructure Technologies Program Multi-Year Research, Development and Demonstration Plan.

A membrane that operates at high temperatures is important to the fuel cell industry because it is insensitive to carbon monoxide (a poison to low-temperature fuel cells), and does not require complex water management strategies. Together, these two benefits greatly simplify the fuel cell system. As a result, the high-temperature fuel cell system realizes a cost benefit as the number of components is reduced by nearly $30 \%$. There is also an inherent reliability benefit as components such as humidifiers and pumps for water management are unnecessary.

Furthermore, combined heat and power (CHP) systems may be the best solution for a commercial, grid-connected, stationary product that must offer a cost benefit to the end user. For a low-temperature system, the quality of the heat supplied is insufficient to meet consumer needs and comfort requirements, so peak heaters or supplemental boilers are required. The higher operating temperature of $\mathrm{PBI}$ technology allows the fuel cell to meet the heat and comfort demand without the additional equipment.

Plug Power, working with the Rensselaer Polytechnic Institute (RPI) Polymer Science Laboratory, made significant advances in optimizing the PBI membrane material for operation at temperatures greater than $160^{\circ} \mathrm{C}$ with a lifetime of 40,000 hours. Supporting hardware such as flow field plates and a novel sealing concept were explored to yield the lower-cost stack assembly and corresponding manufacturing process. Additional work was conducted on acid loss, flow field design and cathode electrode development.

Membranes and MEAs were supplied by team member BASF Fuel Cell (formerly PEMEAS), a manufacturer of polymer and fiber. Additional subcontractors Entegris, the University of South Carolina (USC) Fuel Cell Center, and RPI's Fuel Cell Center conducted activities with regard to stack sealing, acid modeling, and electrode development.

\section{Objectives}

The program objectives were to:

- Select the appropriate polymer chemistry for PBI membrane materials optimized to meet DOE fuel cell requirements

- Demonstrate the long-term performance of the PBI membrane, including its mechanical, electrochemical, and operating properties, in cells and stacks

- Provide a cost analysis of a low-cost membrane manufacturing process to meet DOE cost and high-volume targets. 
Key program activities included:

- Screening of potential PBI-based chemistries and structures and down-selecting the top 5-10 candidate materials based on chemical and physical properties;

- Rapid screening of candidate PBI materials in 50- $\mathrm{cm}^{2}$ MEAs

- Performance of detailed electrochemical characterization of MEAs made with selected PBI polymers

- Evaluation of low-cost, acid-absorbing materials for phosphoric acid management within the system

- Design and development of bipolar plates with PBI-specific flow fields

- Development of a PBI membrane-based MEA with advanced electrode structures providing high catalyst utilization and performance exceeding that of Nafion-based proton exchange membranes.

\section{Technical Approach}

Program activities were conducted concurrently in three main focus areas:

- Focus 1: Polymer and membrane screening and fabrication. Polymer selection, characterization and membrane formation techniques were determined, and membrane materials were identified based on the performance and cost goals.

- Focus 2: MEA characterization. MEA performance was screened, followed by indepth parametric studies for both short-term and long-term application. Scaled-up MEAs of at least $250 \mathrm{~cm}^{2}$ were assembled into short stacks.

- Focus 3: Hardware development and demonstration. In order to develop fuel cell hardware that takes advantage of the full benefits of the high-temperature PBI membrane, a PBI-specific flow field was designed; an acid management strategy was developed; and electrode and MEA performance improvements were pursued. Finally, when all the data were gathered, a model was developed to provide quantitative cost assessment of the PBI-based MEAs.

Individual activities were performed on a small scale, and then put into actual fuel cell testing in a $50-\mathrm{cm}^{2}$ size prior to full-size scale up. In 2007, all the concurrent activities converged in a module demonstration of 16 full-size cells.

\section{Technical Achievements}

The PBI membrane developed by the Plug Power team under this program is applicable to both automotive and stationary fuel cell systems. Additional program achievements, in relation to the 2010 DOE technical targets, are presented in Table 1.

\begin{tabular}{|l|c|c|c|c|c|c|}
\hline Characteristic & Unit & $\begin{array}{c}2004 \\
\text { Status }\end{array}$ & $\begin{array}{c}2005 \\
\text { Status }\end{array}$ & $\begin{array}{c}2006 \\
\text { Status }\end{array}$ & $\begin{array}{c}2007 \\
\text { Program } \\
\text { End }\end{array}$ & $\begin{array}{c}2010 \\
\text { Target }\end{array}$ \\
\hline
\end{tabular}




\begin{tabular}{|c|c|c|c|c|c|c|}
\hline $\begin{array}{l}\text { Membrane } \\
\text { Conductivity }\end{array}$ & $\Omega-\mathrm{cm}^{2}$ & 0.10 & 0.10 & 0.10 & 0.10 & 0.10 \\
\hline $\begin{array}{l}\text { Oxygen } \\
\text { Crossover }\end{array}$ & $\mathrm{mA} / \mathrm{cm}^{2}$ & 5 & 5 & 5 & 5 & 2 \\
\hline $\begin{array}{l}\text { Hydrogen } \\
\text { Crossover }\end{array}$ & $\mathrm{mA} / \mathrm{cm}^{2}$ & 5 & 5 & 5 & 5 & 2 \\
\hline Cost & $\$ / \mathrm{kW}$ & & 2500 & 1500 & 1500 & 1500 \\
\hline $\begin{array}{l}\text { Operating } \\
\text { Temperature }\end{array}$ & ${ }^{\circ} \mathrm{C}$ & 160 & 160 & 160 & 180 & 170 \\
\hline Durability & $\mathrm{hr}$ & 5000 & $>15,000$ & $>15,000$ & $>20,000$ & 40,000 \\
\hline Survivability & ${ }^{\circ} \mathrm{C}$ & -20 & -30 & -30 & -30 & -40 \\
\hline Scalability & $\mathrm{cm}^{2}$ & 50 & 50 & 440 & 440 & 250 \\
\hline
\end{tabular}

Table 1: Progress of Technical Achievements

\section{Accomplishments and Innovations}

The program also resulted in the following noteworthy accomplishments:

- Characterized MEA stress relaxation behavior over time, at room temperature and at operating temperature

- Prepared membranes with fillers and evaluated stress relaxation behavior

- Demonstrated $6.3 \mu \mathrm{V} / \mathrm{hr}$ degradation rate with a $50-\mathrm{cm}^{2}$ test cell at $120^{\circ} \mathrm{C}$ on an unfilled PBI membrane for 13,000 hours, $\mathrm{H}_{2}$ / Air, with no humidification

- Performed load-cycle testing of filled membranes and showed encouraging results with a decrease in degradation rate of nearly half.

- Demonstrated successful acid trapping capability on a short stack test for 2,000 hours

- Built an initial model to understand the acid concentration changes in the MEA as a function of time, temperature and current density

- Evaluated sealing adhesives for chemical compatibility with acid and coolant and performed lap shear tests with adhesive on bipolar plate material

- A rapid approach to allow synthesis of many new PBI-based polymers within a very short turnaround time, such that we were able to screen a great number of polymer compositions in search of a low-cost configuration

- A method to produce PBI that yields very high molecular weight in an economically feasible manner. High molecular weight is a key in fabricating good-quality PBI membrane. 
- A patented sol-gel process to fabricate the membrane, invented by the Dr. Brian Benicewicz, the principal investigator. This is a low-cost, single-step film fabrication method, as compared to the previous multi-step, dip-and-dry process.

- A custom-designed MEA manufacturing pilot line specifically for the PBI material. This pilot line was adapted to the new PPA process.

- A MEA-specific flow field, designed to maximize the unique operating characteristics of $\mathrm{PBI}$ membranes, with special attention to the need of acid management

- An ability to imbibe a large number of phosphoric acid molecules for every PBI repeat unit and a method of acid management to achieve the design lifetime

- An electrode configuration, based on advanced carbon supports, and a unique catalyst layer configuration to improve the catalyst-membrane interface and increase catalyst utilization while reducing platinum loading

- A system design that takes full advantage of the benefits of a PBI membrane, including no humidification, a high $\mathrm{CO}$ tolerance and a simplified reformer

\section{FOCUS 1 RESULTS - \\ POLYMER AND MEMBRANE SCREENING AND FABRICATION}

\section{Task 1-Polymer Membrane Screening and Preliminary Evaluation}

Identification and standardization of characterization test methods. Several meetings were held between Plug Power and RPI to identify a list of specifications for the various MEA components. Test methods used at both Plug Power and RPI were compared to understand any differences. Due to the previous working relationships between the research groups, the majority of the common test methods were closely correlated.

Initial membrane specifications and test methodologies were developed, and standardized analytical procedures were implemented as much as practicable. Where standardized procedures were not feasible, correlations between the results of the different procedures were established.

Identification of alternate formulations to meet membrane specifications. RPI identified the first five different PBI compositions. These PBI-based materials (including the Celtec-P formulation already in use by BASF and Plug Power) vary in their chemical composition and structure. These five compositions were selected because their unique chemical structures had the potential to provide the requisite physical and mechanical properties needed to meet the demands of a high-temperature membrane and may affect overall fuel cell performance. After initial screening tests, RPI provided the preparation methods to BASF. 
Fabrication of alternate membranes. RPI investigated processing of the five initial candidate PBI formulations into membranes. First, monomer purification was conducted for the various compositions, and polymerization reaction experiments were conducted to optimize polymerization conditions (monomer concentration, composition, temperature, and reaction time) and hydrolysis conditions.

Inherent viscosity (IV) measurements provided a relative indication of polymer molecular weight; Table 1 shows that high molecular weight polymers were obtained in all cases. For comparison, the IV of plant-grade PBI produced for fiber applications is generally 0.8 to $1.0 \mathrm{dL} / \mathrm{g}$.

After polymerization, the polymers were formed into membranes, which were in turn analyzed for composition. Specifically, for each membrane, the amounts of polymer, phosphoric acid, and water were determined. Salient data are summarized in Table 2. All of the phosphoric acid concentrations were higher than previously reported for PBI materials.

Each of the polymer materials has a high molecular weight and the corresponding membranes have an acid content significantly greater than that obtained in earlier PBIbased materials and reported in the literature. The syntheses of all five of these compounds were scaled up to at least 1-liter volumes and most were repeated several times to supply sufficient polymer and membrane for testing at Plug Power, BASF, and RPI.

Characterization of alternate membranes. Early in the program, mechanical property testing showed that the various membranes would experience rapid stress relaxation after initial compression, losing up to $90 \%$ of the initial load in minutes. Because this behavior has significant ramifications for stack design, RPI focused its effort on identification of new formulations aimed at improving membrane compression properties.

\begin{tabular}{|c|c|c|c|c|c|c|}
\hline Composition & $\begin{array}{c}\text { IV } \\
\text { (dL/g) }\end{array}$ & $\begin{array}{c}\text { Polymer } \\
\text { content } \\
\text { (wt\%) }\end{array}$ & $\begin{array}{c}\text { Acid } \\
\text { content } \\
\text { (wt\%) }\end{array}$ & $\begin{array}{c}\text { Water } \\
\text { content } \\
\text { (wt\%) }\end{array}$ & $\begin{array}{c}\mathbf{H}_{3} \mathrm{PO}_{4} \text { I } \\
\mathbf{P B I}\end{array}$ & $\begin{array}{c}\text { Conductivity } \\
\text { (S/cm) at 160 } \\
\text { 'C }\end{array}$ \\
\hline 1 & 2.37 & 6.7 & 66.3 & 26.9 & 32 & \\
\hline$($ Celtec-P) & & & & & & \\
\hline 2 & 3.1 & 4.2 & 59.4 & 36.4 & 36 & 0.27 \\
\hline 3 & 3.9 & 6.6 & 54.4 & 38.9 & 24 & 0.28 \\
\hline 4 & 1.3 & 8.9 & 68.2 & 22.7 & 24 & \\
\hline 5 & 4.5 & 7.5 & 63.4 & 29.2 & 21 & \\
\hline
\end{tabular}

Table 2: Chemical and Conductivity Data from Initial Five PBI Formulations 
Composition 4 was scaled up in order to conduct a more thorough evaluation of its properties as a fuel cell membrane candidate. The data are shown in Table 3 . The IV is representative of high molecular weight polymers of this PBI class. The phosphoric acid content is 24 moles per PBI repeat unit and, although higher than literature values for "imbibed" PBI films, was lower than the PPA process can produce for other compositions. This was reflected in the resultant conductivities, shown in Figures 1 and 2.

\begin{tabular}{|c|c|c|c|c|c|}
\hline Composition & $\begin{array}{c}\text { IV } \\
\text { (dL/g) }\end{array}$ & $\begin{array}{c}\text { Polymer } \\
\text { content } \\
\text { (wt\%) }\end{array}$ & $\begin{array}{c}\text { Acid } \\
\text { content } \\
\text { (wt\%) }\end{array}$ & $\begin{array}{c}\text { Water } \\
\text { content } \\
\text { (wt\%) }\end{array}$ & $\mathbf{H}_{3} \mathrm{PO}_{4} / \mathrm{PBI}$ \\
\hline 4 & 14.4 & 55.6 & 29.9 & 24 & 0.10 \\
\hline
\end{tabular}

Table 3: Properties of PBI Composition 4 After Scale-up

The temperature dependence of the ionic conductivity (Figure 1) is lower than reported for other compositions. However, the time-dependent behavior of the conductivity at elevated temperature (Figure 2) is consistent with the behavior seen in many PPA process cast films. There is a slight initial drop in the conductivity, which we believe is due to the removal of water at temperatures above $100^{\circ} \mathrm{C}$, and then a relatively stable ionic conductivity for extended periods.

Typical stress-strain curves for composition 4 are given in Figure 3; in general, films broke at lower stresses and elongations than other compositions that we have reported in the past.

Fuel cell tests with these membranes gave values of approximately $0.58 \mathrm{~V}$ at $0.2 \mathrm{~A} / \mathrm{cm}^{2}$ at $160^{\circ} \mathrm{C}, \mathrm{H}_{2}$ /air (1.2 stoic/2.0 stoic), ambient pressure, $45-\mathrm{cm}^{2}$ cell. Again, this was greater than literature values for "imbibed" films, but not as high as other film compositions prepared by the PPA process. From the comparisons to other films prepared in this program, it was decided that work on composition 2 would be concluded. 


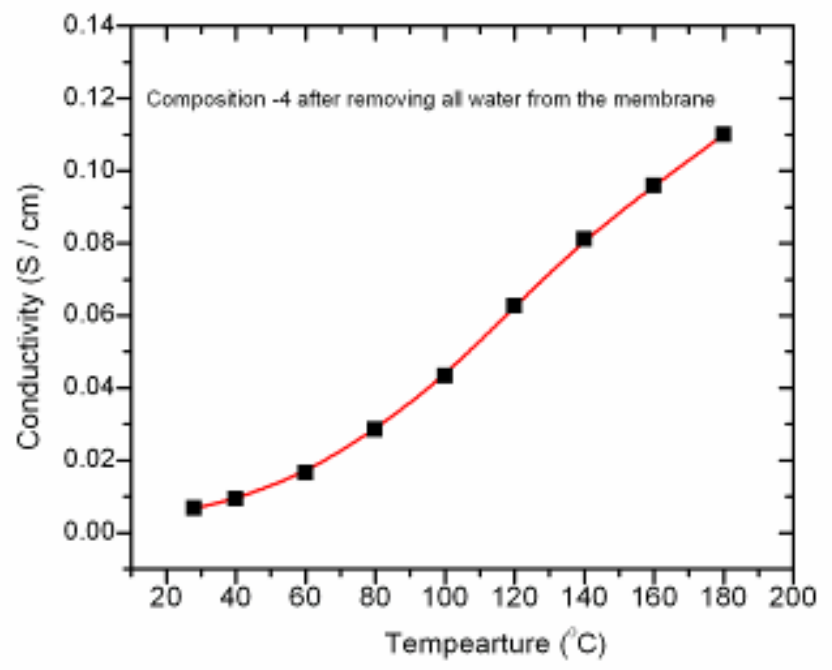

Figure 1: Temperature Dependence of Composition 4

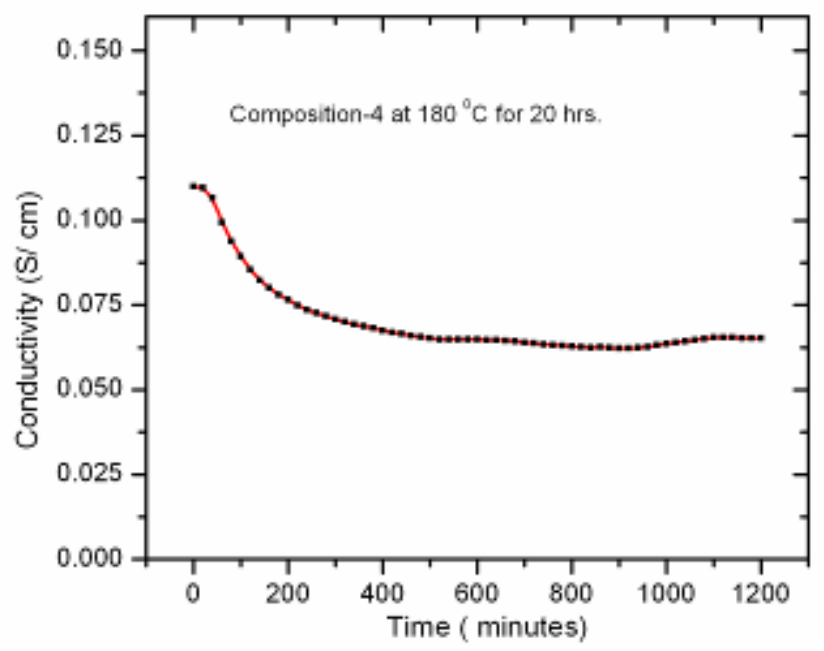

Figure 2: Stability Testing of Ionic Conductivity of Composition 4 


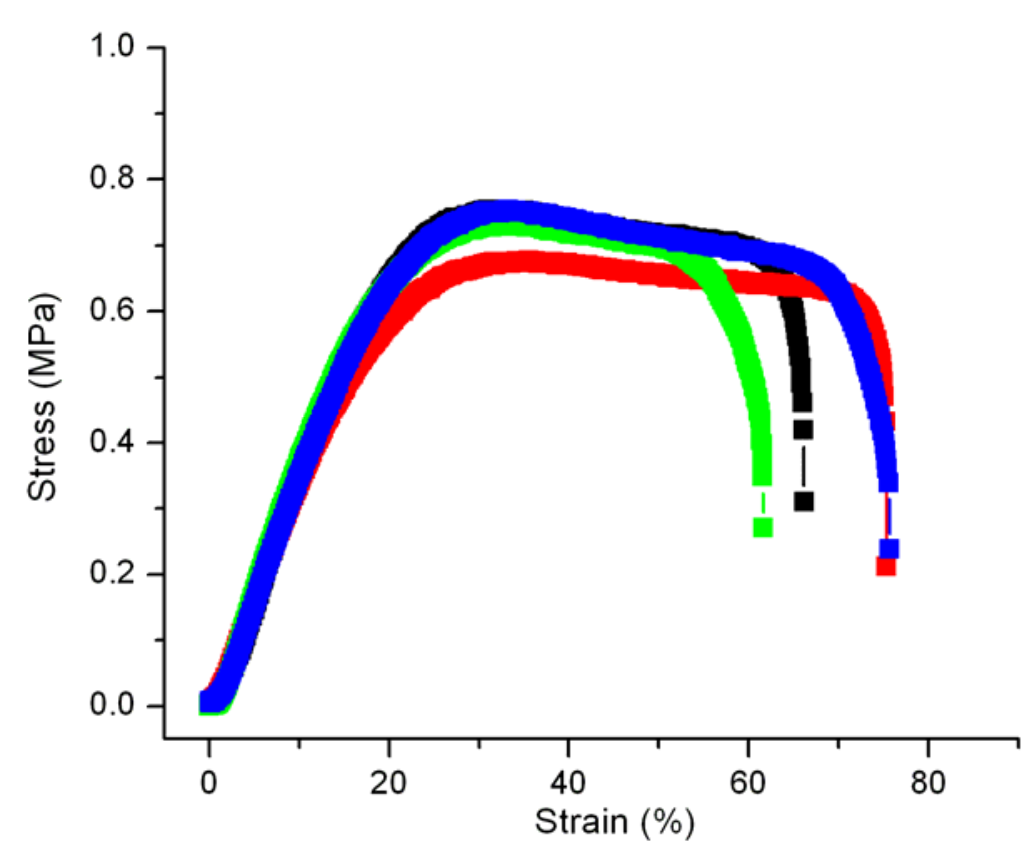

Figure 3: Typical Stress-strain Curves for Composition 4 Film

\section{Task 2-Detailed Polymer Characterization}

Membrane mechanical strength testing. A new load cell, including a low-load detector and a heating chamber with temperature-controlled capability, was installed to enable testing of the high-temperature membrane.

Celtec-P1000 membrane tensile curves at room temperature and $160^{\circ} \mathrm{C}$ are shown in Figure 4. The membrane that was tested at $160^{\circ} \mathrm{C}$ was preheated up to $160^{\circ} \mathrm{C}$ and held at that temperature for 2 hours to allow the acid in the membrane to reach equilibrium. The acid concentration in the membrane after equilibrium at $160^{\circ} \mathrm{C}$ for 2 hours was measured; it was found that the acid concentration increased from $67 \%$ at room temperature to $88 \%$ at $160^{\circ} \mathrm{C}$. During testing at elevated temperature, the membrane was maintained in a heated environment with a relative humidity of $70 \%$.

The results in Figure 4 indicate that the membrane loses tensile strength at elevated temperature. At $160^{\circ} \mathrm{C}$, the membrane exhibits only inelastic deformation. We hypothesized that the increase in acid concentration increases the acid plastic effect on the membrane, which, in turn, increases the polymer free volume, resulting in more chain movement and decreased chain interaction. 
Celtec-P1 000 stress - strain curve at RT and $160^{\circ} \mathrm{C}$

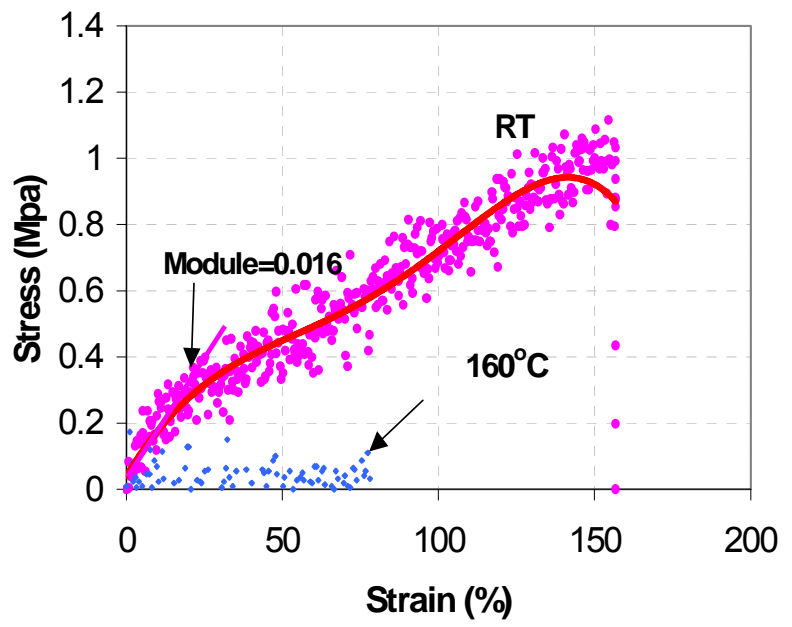

Figure 4: Tensile Curves of Celtec P1000 Membrane

Water transport behavior during cell operation. Water content in the membrane influences membrane properties, particularly conductivity, permeability, and mechanical strength. Therefore, understanding the water transport behavior inside the $\mathrm{MEA} / \mathrm{membrane}$ during cell operation helped us to understand how the membrane properties would change over time.

Table 4 shows our detailed test matrix, which provided a preliminary understanding of the water transport behavior at a variety of fuel cell operating conditions. The water in the reactant inlet and outlet streams was collected and measured; the percentage of water that was produced at the cathode and then transported to the anode was calculated based on differences in these flows. Figure 5 shows the main effect of each parameter on water transportation, while Figure 6 illustrates the interactions between each parameter.

\begin{tabular}{|c|c|c|c|c|c|}
\hline Run Order & $\begin{array}{c}\text { Temp } \\
\left({ }^{\circ} \mathbf{C}\right)\end{array}$ & $\begin{array}{c}\text { Dewpoint } \\
\left({ }^{\circ} \mathbf{C}\right)\end{array}$ & $\begin{array}{c}\text { Current } \\
\left(\mathbf{A} / \mathbf{c m}^{2}\right)\end{array}$ & $\begin{array}{c}\text { Anode } \\
\text { Stoich }\end{array}$ & $\begin{array}{c}\text { Cathode } \\
\text { Stoich }\end{array}$ \\
\hline 1 & 165 & 54.4 & 0.2 & 1.2 & 1.5 \\
\hline 2 & 190 & 46.3 & 0.1 & 1.1 & 1.3 \\
\hline 3 & 190 & 60.4 & 0.1 & 1.1 & 1.7 \\
\hline 4 & 190 & 46.3 & 0.3 & 1.1 & 1.7 \\
\hline 5 & 190 & 60.4 & 0.3 & 1.1 & 1.3 \\
\hline 6 & 190 & 46.3 & 0.1 & 1.3 & 1.7 \\
\hline 7 & 190 & 60.4 & 0.1 & 1.3 & 1.3 \\
\hline 8 & 190 & 46.3 & 0.3 & 1.3 & 1.3 \\
\hline 9 & 190 & 60.4 & 0.3 & 1.3 & 1.7 \\
\hline
\end{tabular}

Table 4: Water Transport Test Matrix 

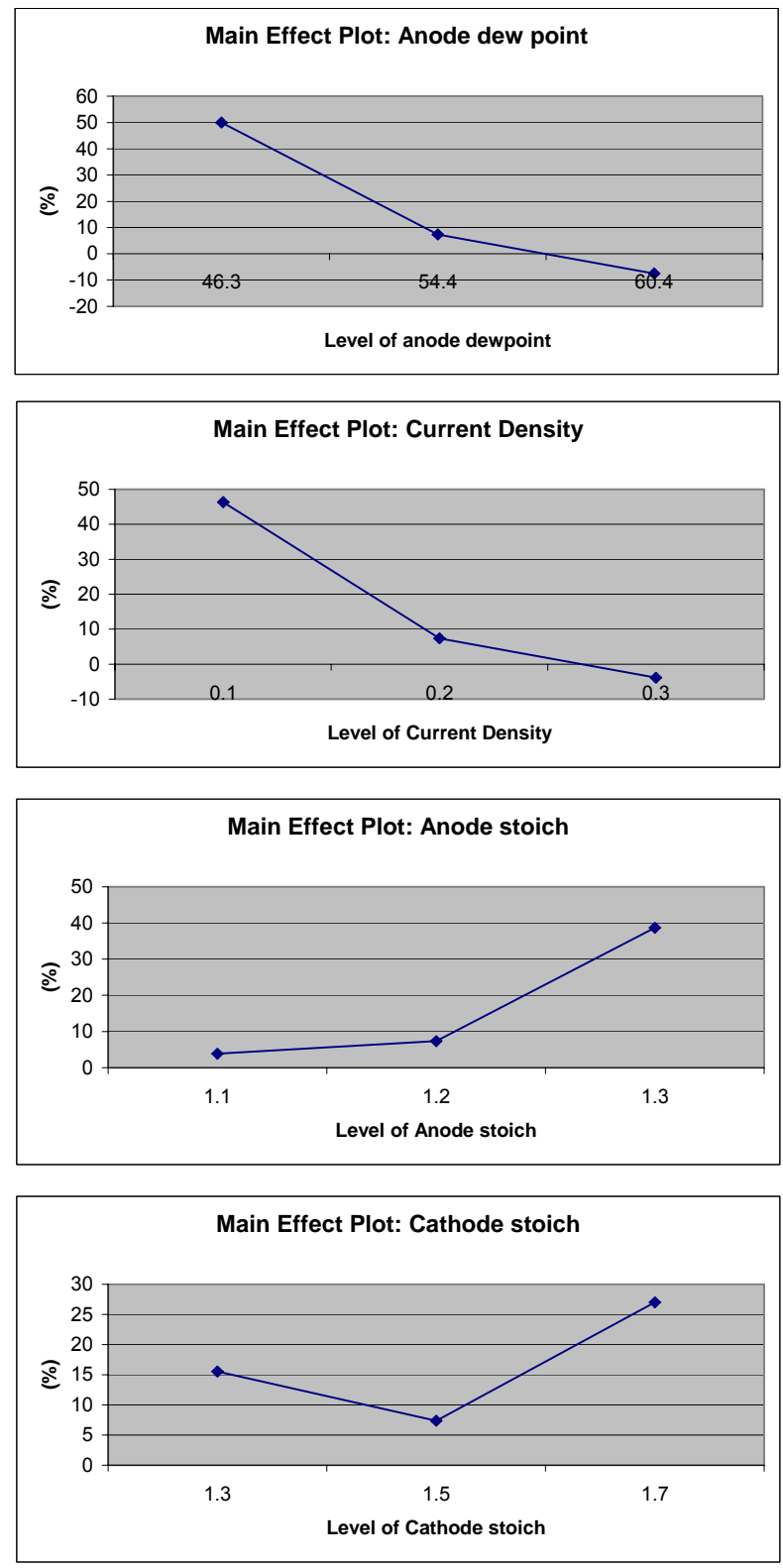

Figure 5: Main Effects Plots from Water Transport Studies 

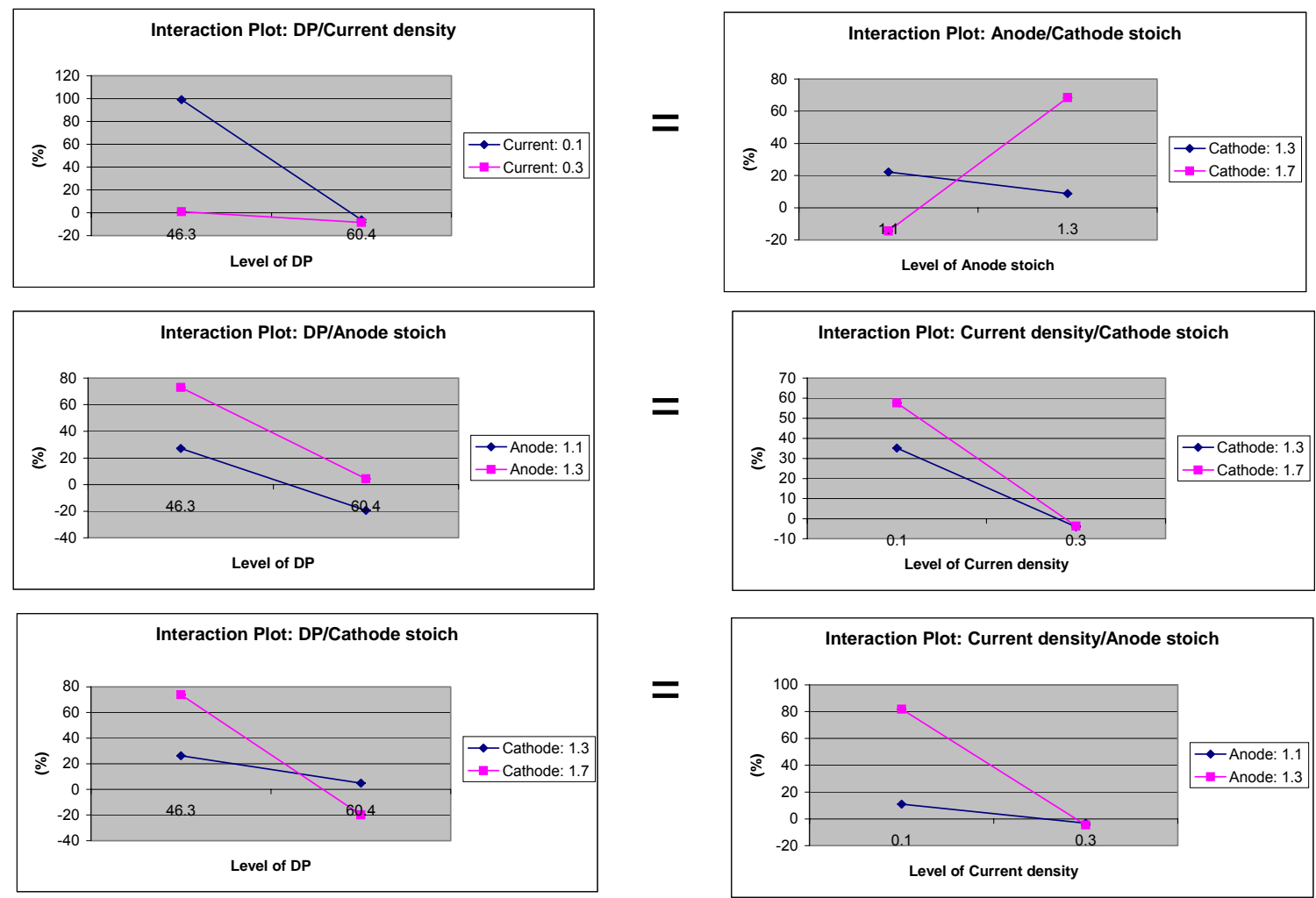

Figure 6: Parameter Interaction Plots from Water Transport Studies

Some preliminary conclusions may be drawn from Figures 5 and 6 :

1. Water can move from anode to cathode or from cathode to anode; the direction of the net transport is strongly dependent upon the operating conditions.

2. The anode gas inlet dewpoint and current density appear to have a strong influence on water transport behavior.

3. It appears that the interaction between current density and anode gas inlet dewpoint is strong; however, the interaction between anode dewpoint and anode stoich is relatively small.

Stress relaxation testing. Different nanoscale filler systems and loading levels between 10 and $30 \%$, based on the weight of polymer in the gel films, were prepared and scaled up. In each case, the polymer and film preparation conditions were tailored to obtain well-dispersed particles. SEM analysis showed that the addition of the nanoparticles did not have much effect on the morphology of the gel and the particles appeared dispersed in the films. Cells built from these filled membranes generally showed performance that was comparable to the unfilled membranes. Figure 7, the SEM photographs for the polymer without filler (on left) and the $10 \mathrm{wt} \%$ silica (on right), demonstrates that the particles are dispersed homogeneously in the films. 


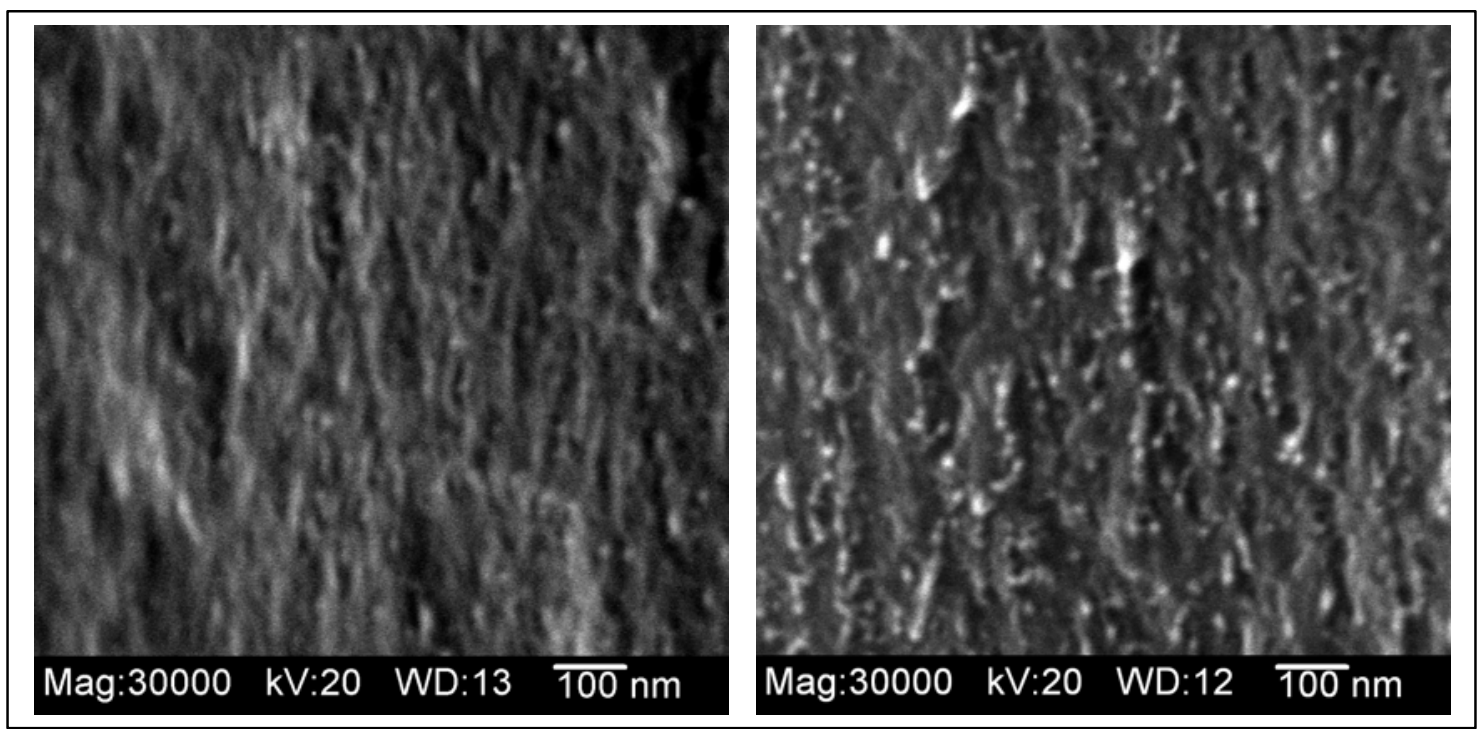

Figure 7: Polymer Without Filler (left), Polymer With Filler (right)

Plug Power creep testers were upgraded to allow testing at high temperature and under controlled humidity conditions simulating the fuel cell environment. Moreover, the test mode was changed from a creep configuration (constant compressive load) to a stress relaxation mode (constant compressive strain) to be more representative of actual conditions.

Preliminary testing is underway on both baseline MEAs and several of the filled membrane specimens, called "Compounds" in this report with 10\%, $20 \%$ and $30 \%$ filler. The nomenclature "Compound 6-20" would represent Compound 6 loaded with 20\% filler.

The testing of baseline MEAs is shown in Figure 8 after 1200 hours. These show significant relaxation reaching the 10 to 20 psi range within the first 1000 hours. 


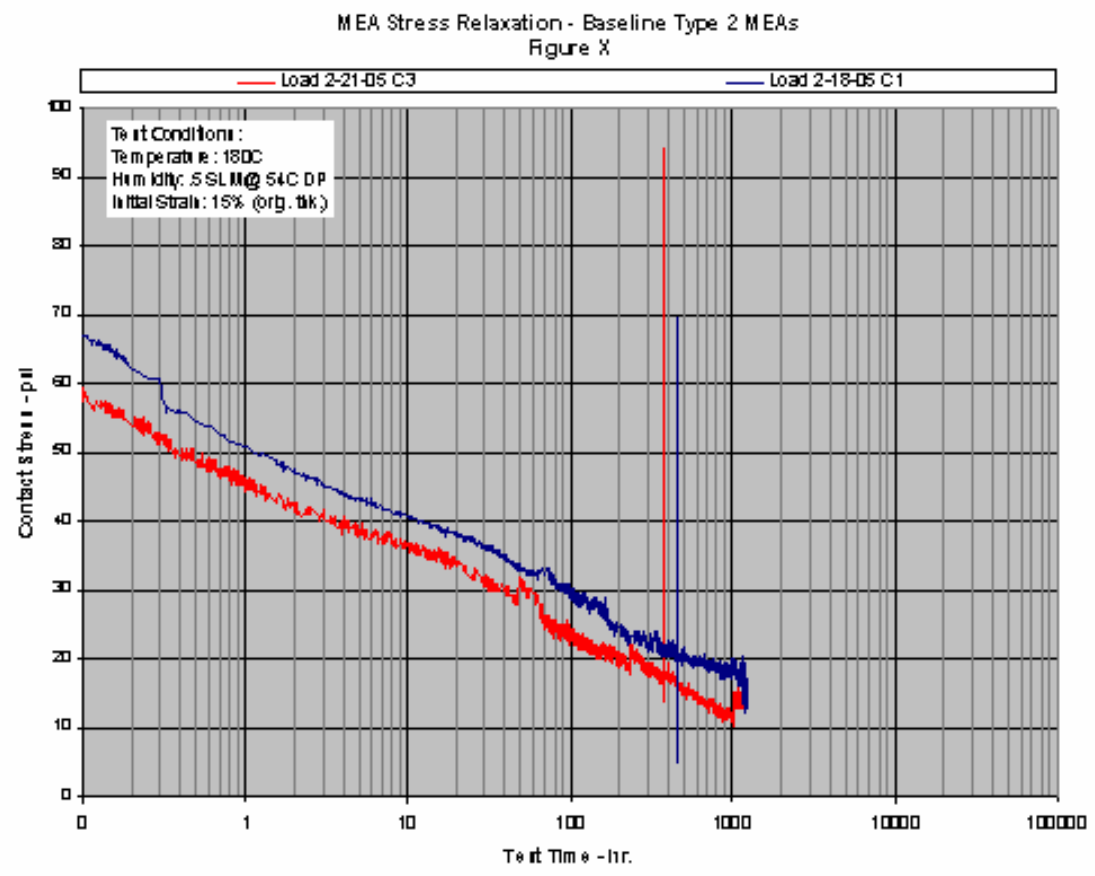

Figure 8: Polymer Without Filler (left), Polymer With Filler (right)

Early results from testing Compound 8-10 and Compound 9-30 show significant stress relaxation and appear to be even worse than baseline membrane material. These are shown in Figure 9 overlaid with the baseline results.

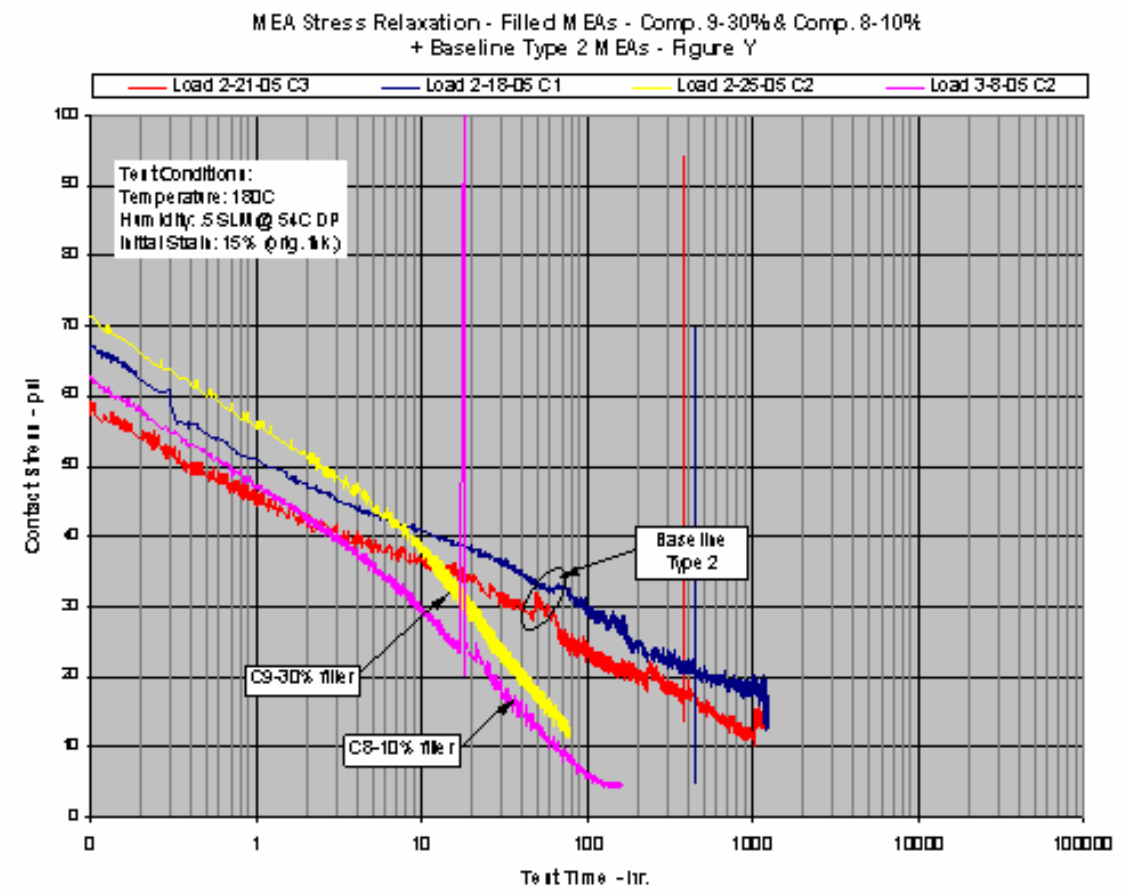


Figure 9: Stress Relaxation of Compounds 8-10, 9-30 and Baseline

Additional compounds were tested with mixed results. While all of the filled specimens showed a consistent initial drop-off, loads leveled off and in some instances actually increased. Other tests of the same membrane types produced opposite results. A fairly substantial effort was made to track down the cause of the differing behavior. At the end of the study the team concluded that despite the load anomalies, all of the MEAs tested are certain to drop to low compressive loads in a relatively short period of time and that the fillers have not proven to be effective in stemming the loss. It was also concluded that the anomalies are most likely due to the humidity conditions in the enclosure. As a result the team decided to continue the stress relaxation testing of the filled specimens at room temperature. This simulated the conditions under which stacks are assembled and avoids the uncertain humidity conditions at high temperature.

The stress relaxation results for Composition 8 specimens are shown in Figure 10 and those for Composition 9 are given in Figure 11. As expected, both Composition 8 and 9 lose load at a slower rate at room temperature $\left(18^{\circ} \mathrm{C}\right.$ to $\left.22^{\circ} \mathrm{C}\right)$ than at $180^{\circ} \mathrm{C}$.

At the end of the first test [Composition 8-0 (SY-2-33 56RH(A))] the rig was heated up to $160^{\circ} \mathrm{C}$, cooled then heated and cooled again. It was observed that the compression load drops from about 33 psi to 4 psi during the first heating and is never regained.

Test observations. Testing included a run on a MEA comprised only of GDL/electrode material, in order to ascertain its contribution. In addition to conducting multi-hundred hour stress relaxation runs, at the end of each run, each rig was subsequently heated up to $160^{\circ} \mathrm{C}$ and then cooled down to determine the effect on load. The resulting stress relaxation curves are presented in Figures 12 to 14 showing Compositions 8,9 and 6 and the unfilled baseline results, respectively.

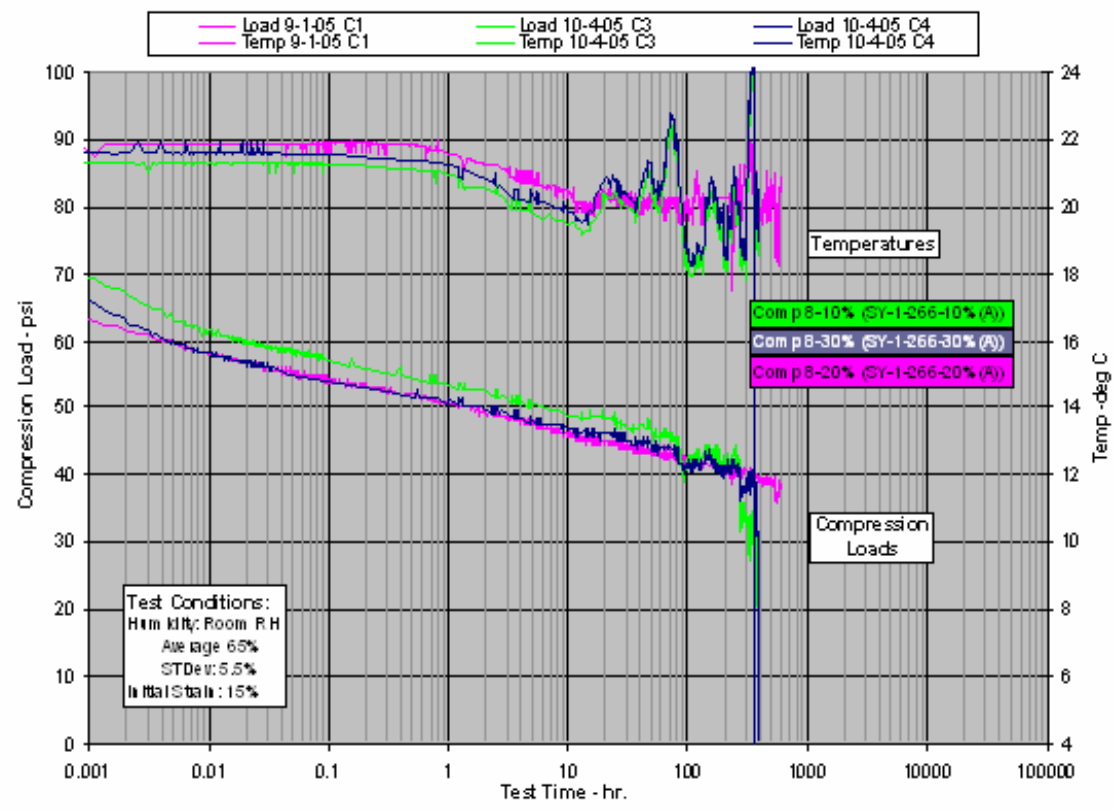


Figure 10: Stress Relaxation - MEAs with Composition 8 Membranes

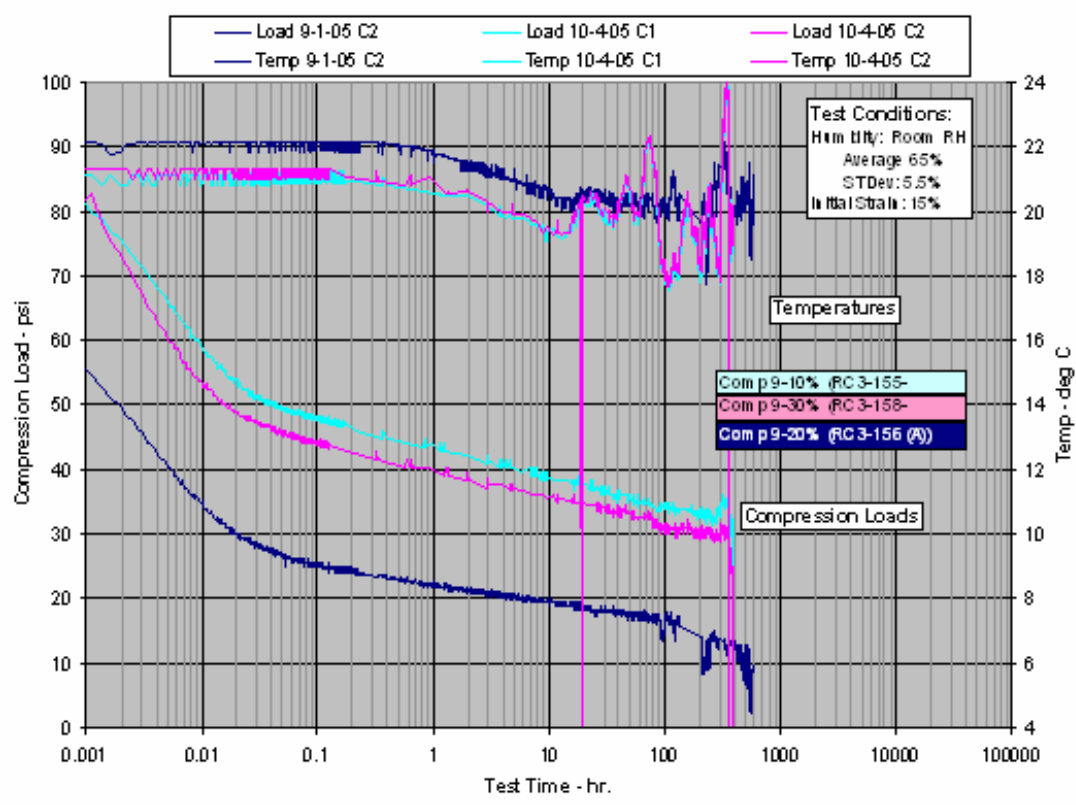

Figure 11: Stress Relaxation - MEAs with Composition 9 Membranes

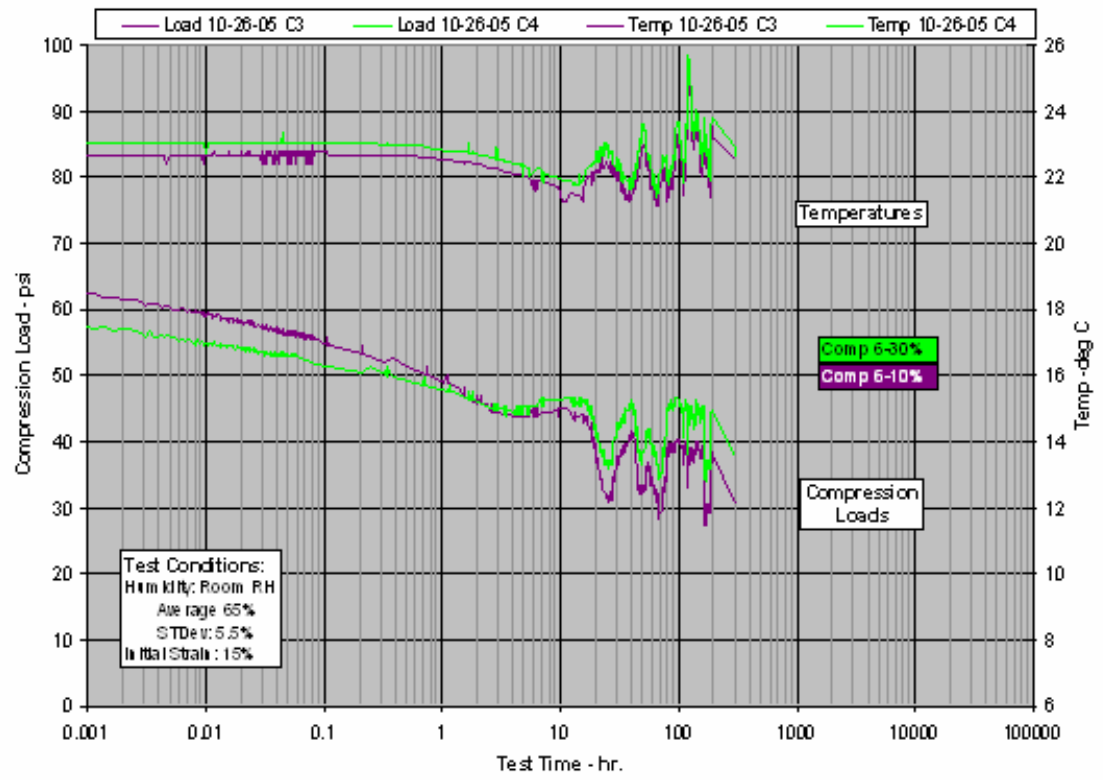

Figure 12: Stress Relaxation - MEAs with Composition 6 Membranes 


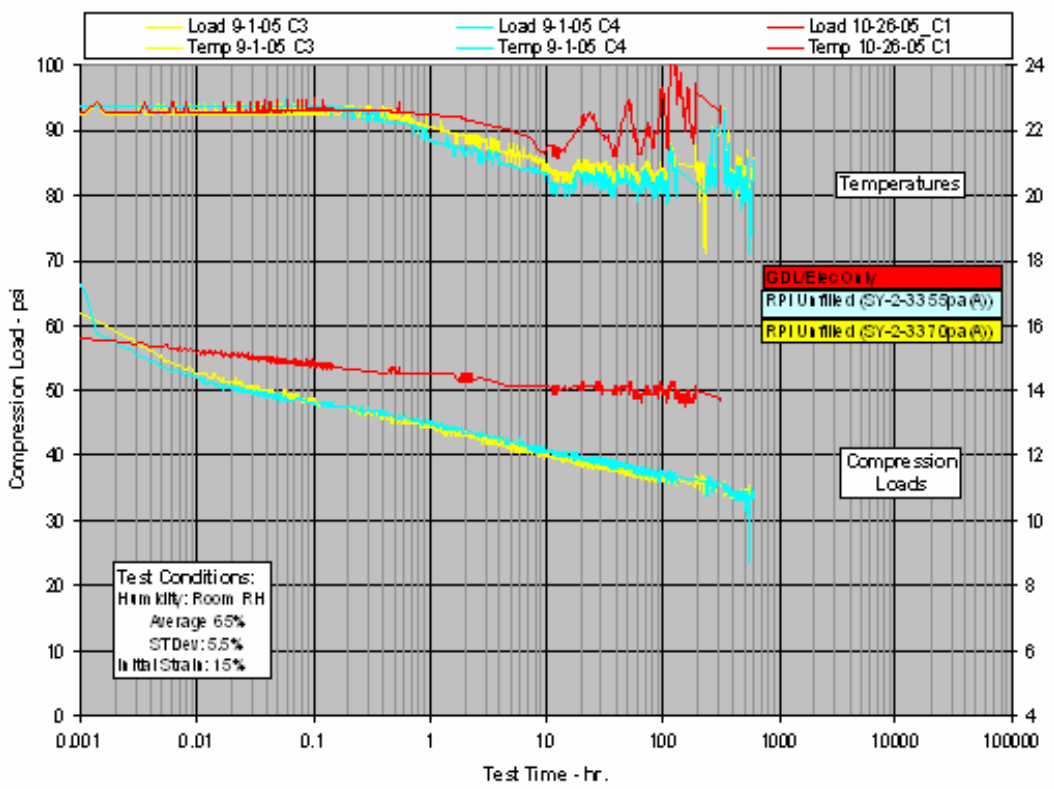

Figure 13: Stress Relaxation - MEAs with Unfilled Membranes \& GDL/electrode

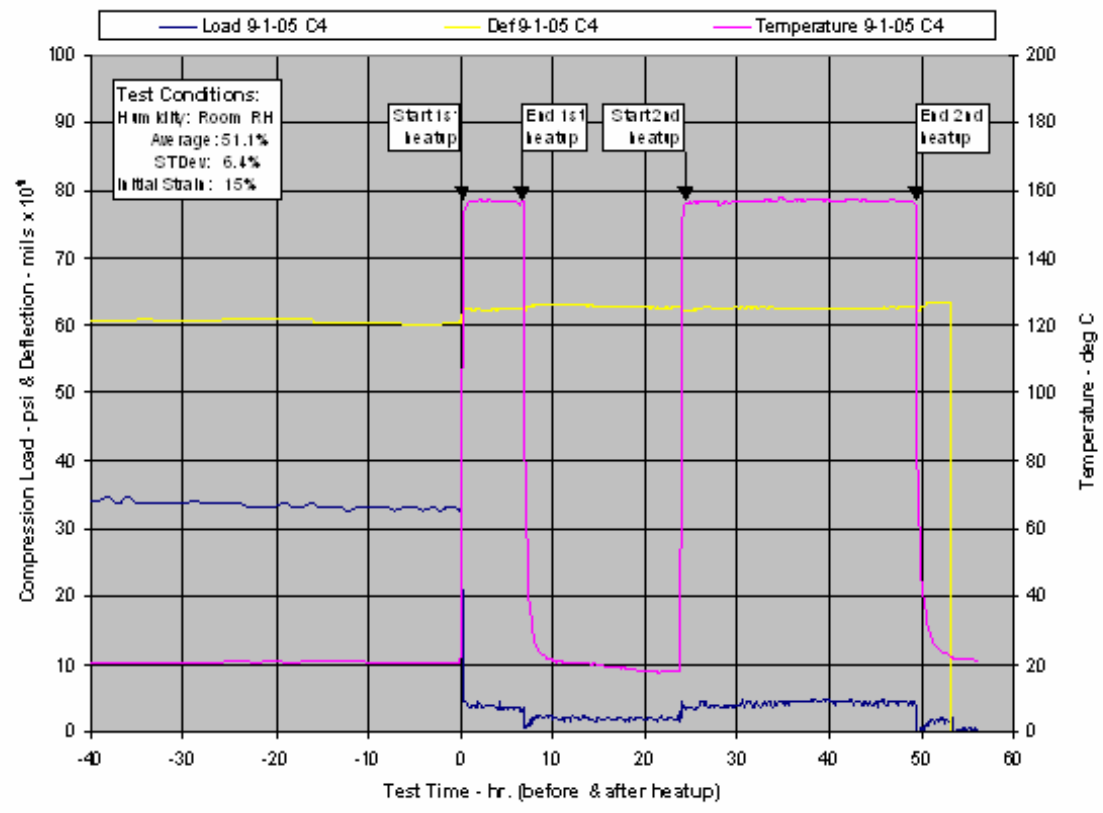

Figure 14: Load Loss with Temperature After $600 \mathrm{hr}$. of Room Temperature Stress Relaxation - MEA Composition 8 Membrane

Two important observations are reflected in the data: 
1. The stress relaxation rates were much less at room temperature than at high temperature. If operation were conducted at this temperature, compression loads probably would not drop below 25 or 30 psi during the 40,000 -hour design life.

2. When subjected to high temperature at the end of the test, the complete MEAs (including membranes) lost load during the heat-up period and did not recover after cool down. The MEA comprised of GDL/electrode material only (no membrane) did not lose any load during heat-up.

Other lesser observations were as follows:

- With one exception, the room temperature curves within each composition group fell very close to each other showing similar stress relaxation rates. This indicates little if any difference among the percentages of filler material. The exception is the Composition 9 with $20 \%$ filler which showed a significantly greater drop-off than the $10 \%$ or $30 \%$ specimens. Based on this and some of the thickness measurements the team believes this specimen may have been compromised in some fashion and may not be indicative of its true behavior.

- There were slight differences in load losses among the specimen types. Composition 8 and 6 specimens dropped to about 40 psi to 45 psi at $100 \mathrm{hr}$ while Composition 9 (excepting C9 $-20 \%$ as noted) and the unfilled specimens decreased to 30 psi to $35 \mathrm{psi}$.

- Compositions 8,6 and baseline were relatively linear with log time. Composition 9 showed an initially high rate of decline which decreased and became uniform several minutes after load application.

- The Composition 6 specimens tended to vary by some $+/-5$ psi on a daily basis roughly correlating with $+/-1^{\circ} \mathrm{C}$ changes in temperature.

- The GDL/electrode MEA predictably showed very little stress relaxation decreasing from about 57 psi to 49 psi over some 300 hours. This indicates that most of the load loss is due to the relaxation of the membranes.

Taken in total, including both the earlier high-temperature testing and the recently completed room temperature testing, followed by the heat-up test, we concluded that none of the filled or unfilled compositions tested are capable of maintaining significant compression load (>20 psi) for a significant period of time when operated at high temperatures $\left(>160^{\circ} \mathrm{C}\right)$. Also, while there are many factors influencing the rate of stress relaxation, it appeared that the effect of temperature simply overwhelms the filled structures and results in rapid stress relaxation.

\section{Task 3 - Low-Cost Membrane Formation Techniques}

A variety of membrane formation techniques were reviewed as part of this program including casting and roll-to-roll manufacturing processes. Each technique has its benefits and drawbacks. For example: casting lends itself well to a batch process 
where the formulations will evolve over time as better membrane formulations are developed. Its drawbacks are batch to batch variability and large scale production. Roll-to-roll on the other hand works very well in large scale production but is capital hardware intensive and is relatively inflexible to batch changes.

Due to the initial results and the difficulty in determining which membrane formulation and which filling level, if any, provides a clear benefit to the membrane's performance, this activity was deemphasized in favor of membrane optimization. It was deemed inappropriate to spend limited program resources on an activity so dependent on the outcomes of the other program tasks until they were complete. Some of these initiatives, while advanced significantly during the course of this program will be completed after its end date. Since the outcomes of these tasks will dictate in large part the low-cost techniques adopted the actual selection of the final technique will be beyond the scope of this program.

\section{Task 4-Membrane Scale-up}

RPI conducted detailed studies to: 1) examine the phosphoric acid movement and loss from the MEA during the separate steps of cell assembly, heat-up and operation under different conditions; 2) analyze degradation rates under various load-cycling conditions; and 3) develop a startup/shutdown profile that reduces the time that the cell voltage is larger than $0.8 \mathrm{~V}$. The studies also explored the effect of cell voltage greater than $0.8 \mathrm{~V}$ on the cell's performance degradation.

The results of these studies are presented in the following sections.

\section{Phosphoric Acid Loss/movement Testing}

Background and Objective. Phosphoric acid (PA) doped polybenzimidazoles (PBI) as membranes for high temperature polymer electrolyte membrane fuel cells (PEMFC) have been described in the literature [1-6]. These membranes show distinct advantages such as high cell operation temperature (between $120^{\circ} \mathrm{C}$ and $200^{\circ} \mathrm{C}$, high fuel impurity tolerance (CO up to $3 \%, \mathrm{H} 2 \mathrm{~S}$ up to $10 \mathrm{ppm}$, etc.), no need for water management, and high efficient waste heat usage.

Phosphoric acid plays a major role in proton transport for this type of membrane. The amount and distribution of phosphoric acid in the membrane electrode assembly (MEA) are critical for the fuel cell's performance, especially for longer times of operation. Research at Plug Power showed that after a cell ran for 4,000 hours the MEA had only approximately $47 \%$ phosphoric acid remaining compared to the MEA at the start of the test and the thickness of the membrane was less than 1 mil. The cell also displayed low OCV and cross leaks. In this study, a comprehensive analysis of phosphoric acid loss/movement from the MEA during cell assembly, initial heat-up and cell operation are measured through a series of structured tests. Additionally, the phosphoric acid 
available for operation, its movement within and out of the cell (MEA or flow plates) and the point at which acid loss degrades the performance are determined. Ultimately, the relationship between membrane thickness and phosphoric acid content is discussed.

Design of experiments. The details of the experimental design are shown in Table 5 and described here with more complete explanations. Sample 0 was a commercial MEA (PEMEAS, Celtec-P 1000) and used as a reference sample. Samples (1-3) were designed to test phosphoric acid loss/movement caused by cell assembly. The phosphoric acid in the MEAs was measured after the cells were assembled and held at room temperature for zero, 0.5 , and 48 hours, respectively. Samples (4-6) were designed to test phosphoric acid loss/movement from the cell during initial heat-up.

First, the fuel cells were assembled and heated to the set temperature. After reaching the set temperature of either $160^{\circ} \mathrm{C}$ or $180^{\circ} \mathrm{C}$, the cells were held at the set temperature for zero, 0.5 , and 48 hours, respectively. Then the cells were cooled to room temperature and the phosphoric acid in the MEAs was tested. Samples (7-12) were designed to test the phosphoric acid loss/movement during the cell operation. Two variables were considered here: (1) cell operation temperature- $160^{\circ} \mathrm{C}, 180^{\circ} \mathrm{C}$; (2) cell operation time--100 hours, 500 hours, and 2500 hours. The phosphoric acid in the MEAs was tested after cell operation.

\begin{tabular}{|c|c|c|c|c|}
\hline Sample & Time, hr & Temp, ${ }^{\circ} \mathrm{C}$ & Anode & Cathode \\
\hline 0 & \multicolumn{4}{|c|}{ commercial MEA as received } \\
\hline 1 & 0 & RT & $/$ & $/$ \\
\hline 2 & 0.5 & RT & $/$ & $/$ \\
\hline 3 & 48 & RT & $/$ & $/$ \\
\hline 4 & 0 & 160 & $/$ & $/$ \\
\hline 5 & 0.5 & 160 & $/$ & Air \\
\hline 6 & 48 & 180 & $\mathrm{H}_{2}$ & Air \\
\hline 7 & 100 & 160 & $\mathrm{H}_{2}$ & Air \\
\hline 8 & 100 & 180 & $\mathrm{H}_{2}$ & Air \\
\hline 9 & 500 & 160 & $\mathrm{H}_{2}$ & Air \\
\hline 10 & 500 & 180 & $\mathrm{H}_{2}$ & Air \\
\hline 11 & 2500 & 160 & $\mathrm{H}_{2}$ & \\
\hline 12 & 2500 & 180 & & $/$ \\
\hline
\end{tabular}

Table 5: Design of Experiments

Experimental. Cells were assembled using the RPI protocol--applying the torque on bolts gradually, at 15 inch-pounds, 30 inch-pounds, 45 inch-pounds, sequentially. The gasket thickness was $80 \%$ of MEA thickness. Phosphoric acid in the MEAs was 
measured by $\mathrm{NaOH}$ titration of the MEA at 9 different places to assess the PA distribution across the MEA (Figure 15). The radius of each punch was one centimeter.

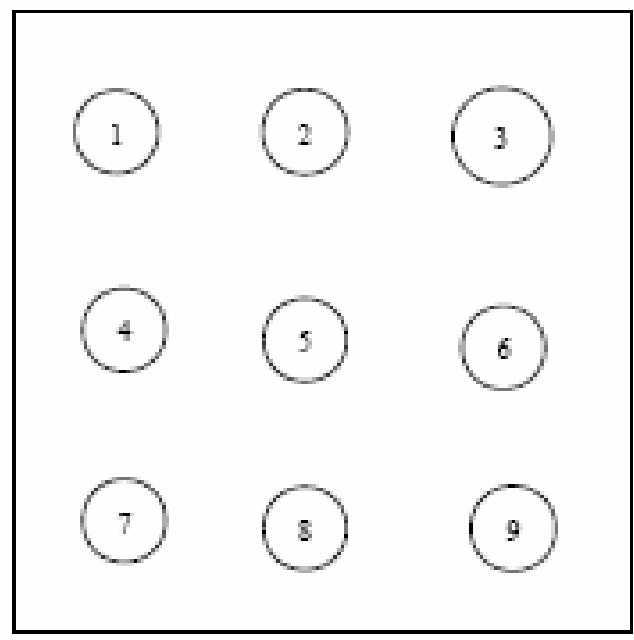

Figure 15: Measurement of Phosphoric Acid in the MEA.

During the cell operation, the exhaust water was collected and phosphoric acid in collected exhaust water was measured using a Lachat ion chromatography QuickChem $8000 \mathrm{IC}+$ instrument. The instrument can determine the concentration of o-phosphate-P in the range 0.05 to $5 \mathrm{mg} / \mathrm{L}$ (ppm).

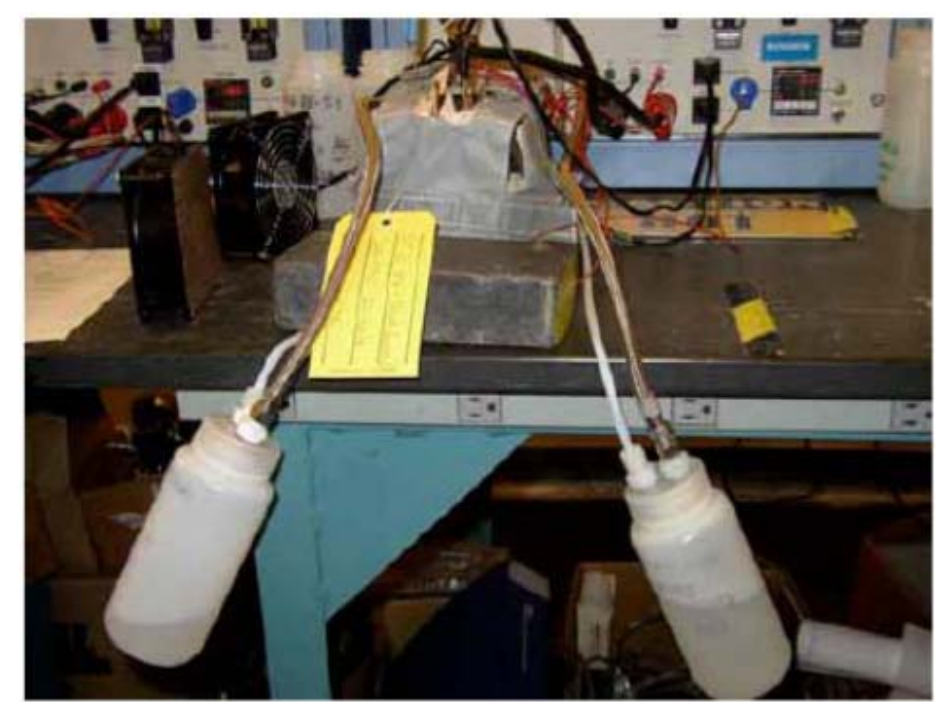

Figure 16: Exhaust Water Collection

Membrane thickness was measured using an Olympus PMG3 stereomicroscope with $200 \mathrm{X}$ magnification. MEAs were cut on four corners using a sharp scalpel. Three photomicrographs were taken on each corner; four length readings were done on each photomicrograph. Thus, a total of forty-eight thicknesses were measured on each MEA sample to map out the membrane thicknesses. 


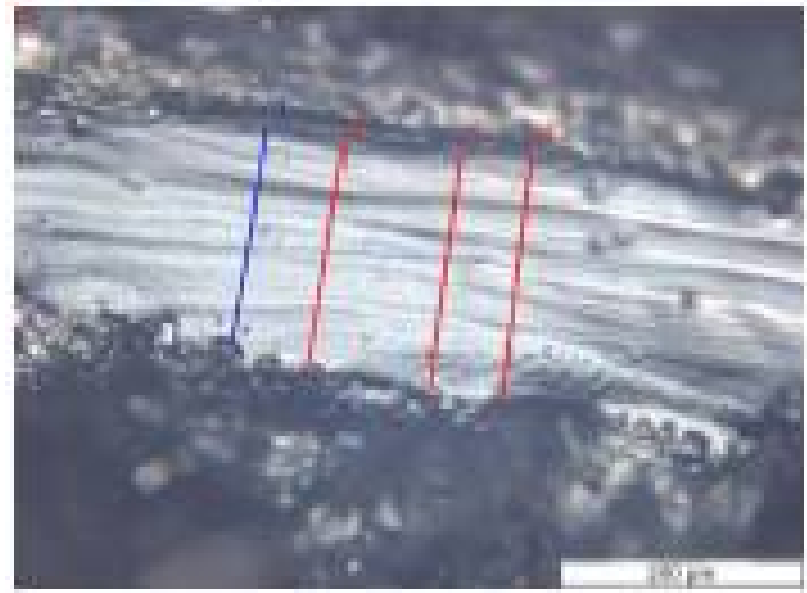

Figure 17: Example of Membrane Thickness Measurement via Stereomicroscope

Phosphoric Acid in the MEA. Cell assembly, initial heat-up and cell operation all cause PA loss/movement in the MEA (detail data are shown in Table 6). The cell assembly resulted in PA loss/movement from the MEA from approximately $8 \%$ (Sample 1) to approximately $30 \%$ (Sample 3 ).

\begin{tabular}{|c|c|c|c|c|c|}
\hline Sample \# & Description & $\begin{array}{l}\text { Tine } \\
\text { (nours) }\end{array}$ & $\begin{array}{l}\text { Temp } \\
\text { ("C) }\end{array}$ & $\begin{array}{c}\text { PA In MEA } \\
\left(\mathrm{mg} / \mathrm{cm}^{2}\right)\end{array}$ & $\begin{array}{c}P A / 100 \%) \text { wt } \% \\
\text { In MEA }\end{array}$ \\
\hline 0 & Reference & 0 & RT & 24.7 & $32.7 \%$ \\
\hline 1 & \multirow{3}{*}{$\begin{array}{l}\text { Efrect of the } \\
\text { cell } \\
\text { assembly }\end{array}$} & 0 & RT & 22.6 & $30.7 \%$ \\
\hline 2 & & 0.5 & RT & 19.7 & $29.9 \%$ \\
\hline 3 & & 48 & RT & 17.2 & $27.2 \%$ \\
\hline 4 & \multirow{3}{*}{$\begin{array}{c}\text { Effect of cell } \\
\text { Inlitial } \\
\text { heat-up }\end{array}$} & 0 & 160 & 16.9 & $27.2 \%$ \\
\hline 5 & & 0.5 & 160 & 16.0 & $25.9 \%$ \\
\hline 6 & & 48 & 180 & 15.8 & $25.9 \%$ \\
\hline 7 & \multirow{6}{*}{$\begin{array}{c}\text { Effect of cell } \\
\text { operation }\end{array}$} & 100 & 160 & 21.5 & $31.2 \%$ \\
\hline 8 & & 100 & 180 & 19.0 & $29.5 \%$ \\
\hline 9 & & 500 & 160 & 20.8 & $31.0 \%$ \\
\hline 10 & & 500 & 180 & 18.8 & $29.9 \%$ \\
\hline 11 & & 2500 & 160 & 16.8 & $27.3 \%$ \\
\hline 12 & & 2500 & 180 & 9.7 & $18.2 \%$ \\
\hline
\end{tabular}

Table 6: Phosphoric Acid Content in the MEA.

These samples were held under compression at room temperature. Here, we use Sample 0 as the reference sample and assume that all the samples were similar and had the same PA content at the initial state. This part of the PA loss/movement from the MEA can be simply attributed to the mechanical pressure on the MEA during the cell assembly and holding time under pressure. As stated above, the thickness of the gaskets was $80 \%$ of MEA thickness. The amount of PA lost from the MEA increased with the time that the cell was held under pressure at room temperature. Thus, under 
fairly standard compression conditions, pressure results in some loss of PA and water from the MEA.

The initial heat-up also caused the phosphoric acid loss. For our cell hardware, approximately 1 hour was required to heat-up from room temperature to $160^{\circ} \mathrm{C}$. When the cell was assembled and held at room temperature, the loss of phosphoric acid was gradual during the initial 48 hours (Figure 18). This loss can be reasonably ascribed to mechanical pressing of liquid out of the MEA. When the cell was assembled and heated immediately, the initial loss was greater (within the first $0.5 \mathrm{hr}$ ), but appeared stable during the next $48 \mathrm{hrs}$ at both $160^{\circ} \mathrm{C}$ and $180^{\circ} \mathrm{C}$. It should be remembered that the initial heat-up results in the condensation of phosphoric acid molecules into dimers with the subsequent loss of water from the condensate as well as the free water that was in the initial MEA.

$$
2 \mathrm{H}_{3} \mathrm{PO}_{4} \rightarrow \mathrm{H}_{4} \mathrm{PO}_{4}+\mathrm{H}_{2} \mathrm{O}
$$

The larger initial weight loss of water and phosphoric acid (from the steam formed during heat up) is consistent with the limited data in these tests.

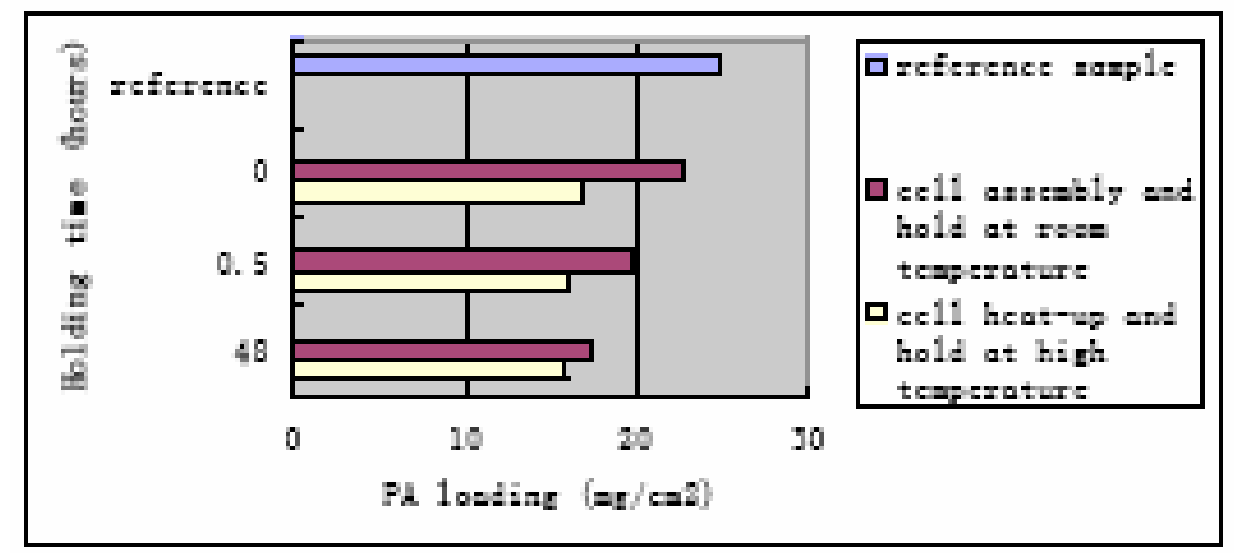

Figure 18: Effect of Cell Assembly and Initial Heat-up on PA Content in the MEA

Phosphoric acid loss also occurs during the cell operation (Samples 7-12). After more than 2500 hours of cell operation at $180^{\circ} \mathrm{C}$, the phosphoric acid in the MEA was only about $40 \%$ of the reference sample. We assume that all the samples were similar and had the same PA content at the initial state. Thus, the sample lost about $60 \%$ of PA after more than 2500 hours operation at $180^{\circ} \mathrm{C}$. Also, PA loss from the MEA increased with the cell operation temperature and increasing time. This part of the phosphoric acid loss is likely due to the phosphoric acid evaporation at the cell operation temperatures, although the literature vapor pressure of pure liquid phosphoric acid is very low at these temperatures. The higher vapor pressure of phosphoric acid at $180^{\circ} \mathrm{C}$ versus $160^{\circ} \mathrm{C}$ probably accounts for the higher phosphoric acid loss rate at the higher temperature (Figure 19). 


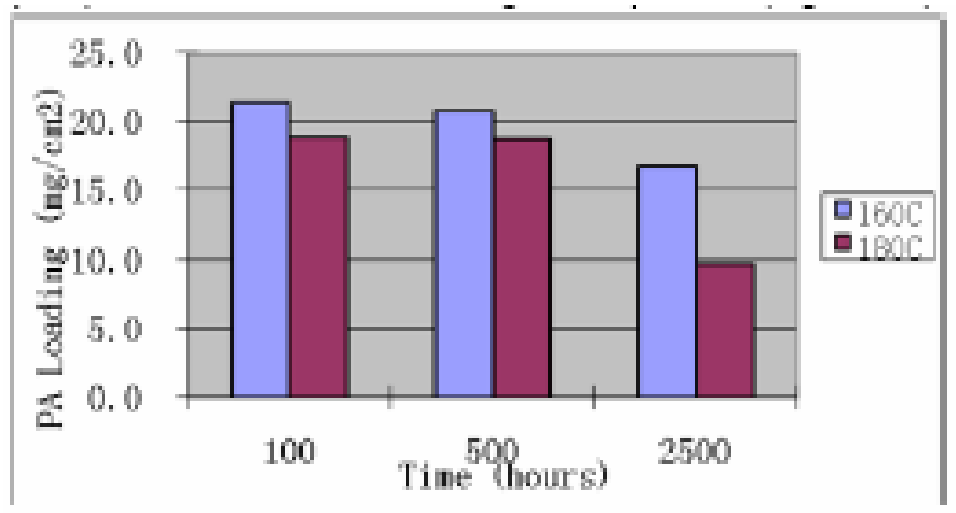

Figure 19: PA in the MEA After Operation at Different Temperatures

There is an apparent inconsistency in between Samples 4-6 and Samples 7-12. The phosphoric acid content in Samples 4-6 are substantially lower than Samples 7-10 even though the later samples were operated for various periods of time which were longer than the simple assembled cells. For comparison, the phosphoric acid contents in Samples 4-6 are similar to Sample 11 that had been operated at $160^{\circ} \mathrm{C}$ for more than 2500 hours. Thus, why do the non-operated systems (Samples 4-6) have higher phosphoric acid loss than the systems (Samples 7-10) which were operated for 100 and 500 hours?

One important experimental difference is that Samples 1-3 and 4-6 were closed systems with no gas flows during the holding and heating periods, and Samples 7-12 were open systems with gases flowing during the holding and heating periods. Another set of experiments was conducted to test the effect of closed versus open system during initial heat up. This data is shown in Figure 20. In this figure, the data from above is replicated and combined with identical experiments, except that the cells were either open to the atmosphere or open with air flows $(20 \mathrm{ml} / \mathrm{min})$ on both anode and cathode sides.

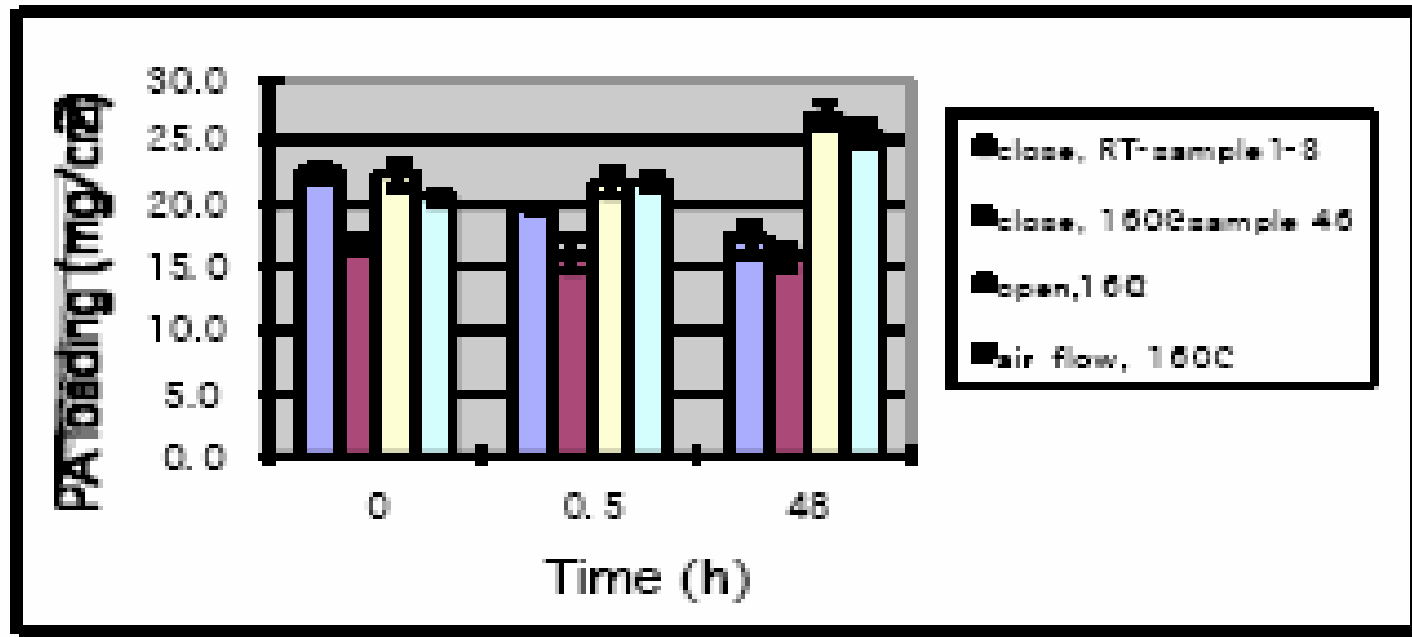




\section{Figure 20: Phosphoric Acid Losses in the MEA of Closed Versus Open Systems}

Clearly, the closed systems have higher phosphoric acid loss/movement from MEA than the open systems. This is especially observed in the closed and heated systems (Samples 4-6), where phosphoric acid loss/movement was the highest. The open systems and systems with air flow have the smallest phosphoric acid loss/movement. Without providing an explanation, the data suggests that closed systems during the initial heat up period should be avoided.

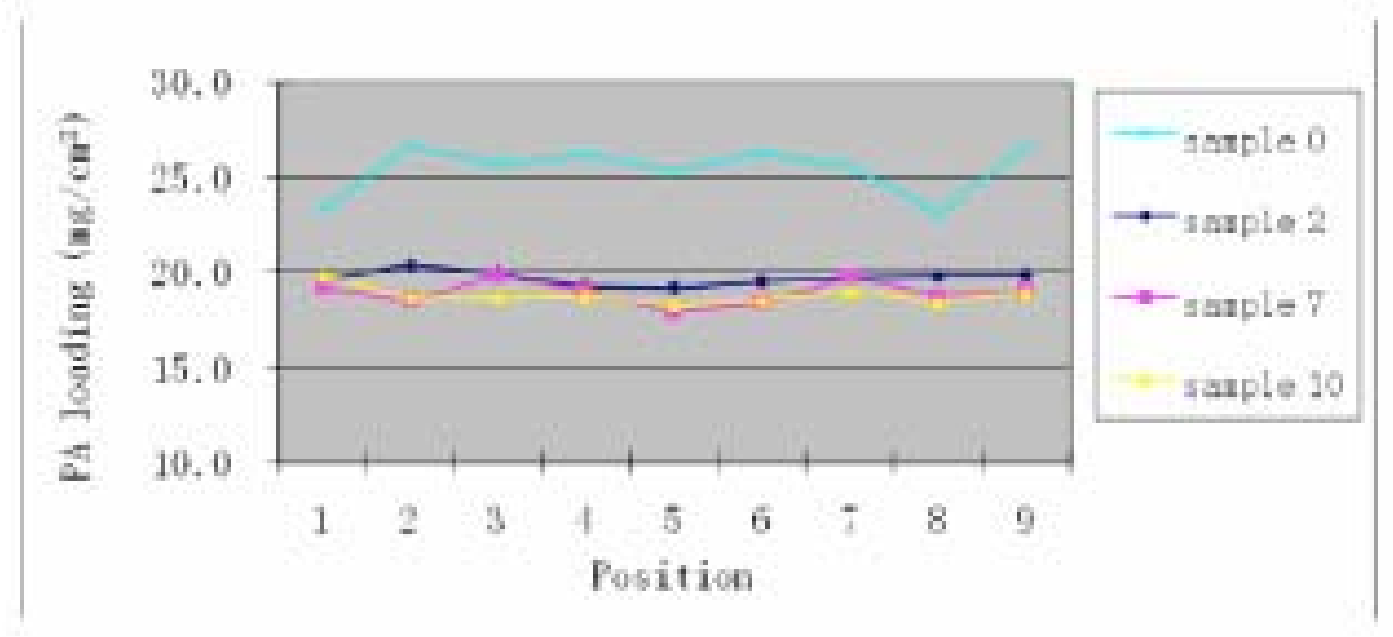

Figure 21: PA Distribution in MEA

Our experimental design also looked for differences in the loss of phosphoric acid from the anode and cathode inlets and outlets. As shown in Figure 21, the distribution of phosphoric acid in the MEA was quite even across the surface matrix at all operation times up to 2500 hours.

Membrane Thickness. Significant thickness reduction of the membrane during cell assembly, initial heat-up and cell operation were observed. The membrane thickness changed from approximately 8 mils in the reference MEA, to approximately 5 mils after cell assembly, to approximately 3 mils after the initial heating, to less than 2 mils after cell operation for more than 2500 hours. 


\begin{tabular}{|c|c|c|c|}
\hline Brrpla & Desctpton & Membrane Thlahess & 9 \\
\hline Bample 0 & Reference & 194 -mntionil & $15 \mu m$ untonil \\
\hline Sample 1 & \multirow{3}{*}{$\begin{array}{l}\text { EHect of the } \\
\text { cell asemby }\end{array}$} & $150-750$ mil & $25-\mathrm{m} / \mathrm{ml}$ \\
\hline Bample 2 & & 15 -m52ail & 35 min \\
\hline Bample 3 & & $125-740$ ail & $25 m / n i$ \\
\hline Bample 4 & \multirow{3}{*}{$\begin{array}{l}\text { Eftst ot cel } \\
\text { l-l:al leat-up }\end{array}$} & 6) $\mu \mathrm{m} / 3 \mathrm{ng}$ & 15 umon finil \\
\hline Sample 5 & & $94 \mu \mathrm{m} / 4 \mathrm{An}$ & 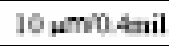 \\
\hline Sample 5 & & $104+1 \mathrm{~m} 4 \mathrm{ln}-1$ & 12 umbust \\
\hline Sample 7 & \multirow{6}{*}{$\begin{array}{c}\text { Eflect ot cel } \\
\text { operats }\end{array}$} & $84 \mathrm{~m} 39 \mathrm{n}]$ & 8 m.t.3nil \\
\hline Sample 3 & & 7 нm/4n] & 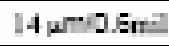 \\
\hline Eample 9 & & 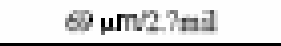 & 9.min.Anil \\
\hline Semple to & & $55 \mu \mathrm{m} / 2 \mathrm{mal}$ & 6-ma.znil \\
\hline Bample 11 & & $5 \mu \mathrm{m} / \mathrm{nn}$ & S_mo.Znil \\
\hline Bgmple 12 & & Thar $1 \mathrm{fm}$ & $4 \pi=0 \mathrm{nI}$ \\
\hline
\end{tabular}

Table 7: Membrane Thickness

A rough decreasing tendency can be seen between the PA loading with membrane thickness (Figure 22). These phenomena can be explained by low polymer content in this type of membrane (initially only about $5 \mathrm{wt} \%$ ). The major components of the membrane are phosphoric acid and water, so the thickness of membrane is mainly based on the content of phosphoric acid and water. With the phosphoric acid and water loss, the membrane becomes thinner during the initial processing and heat-up.

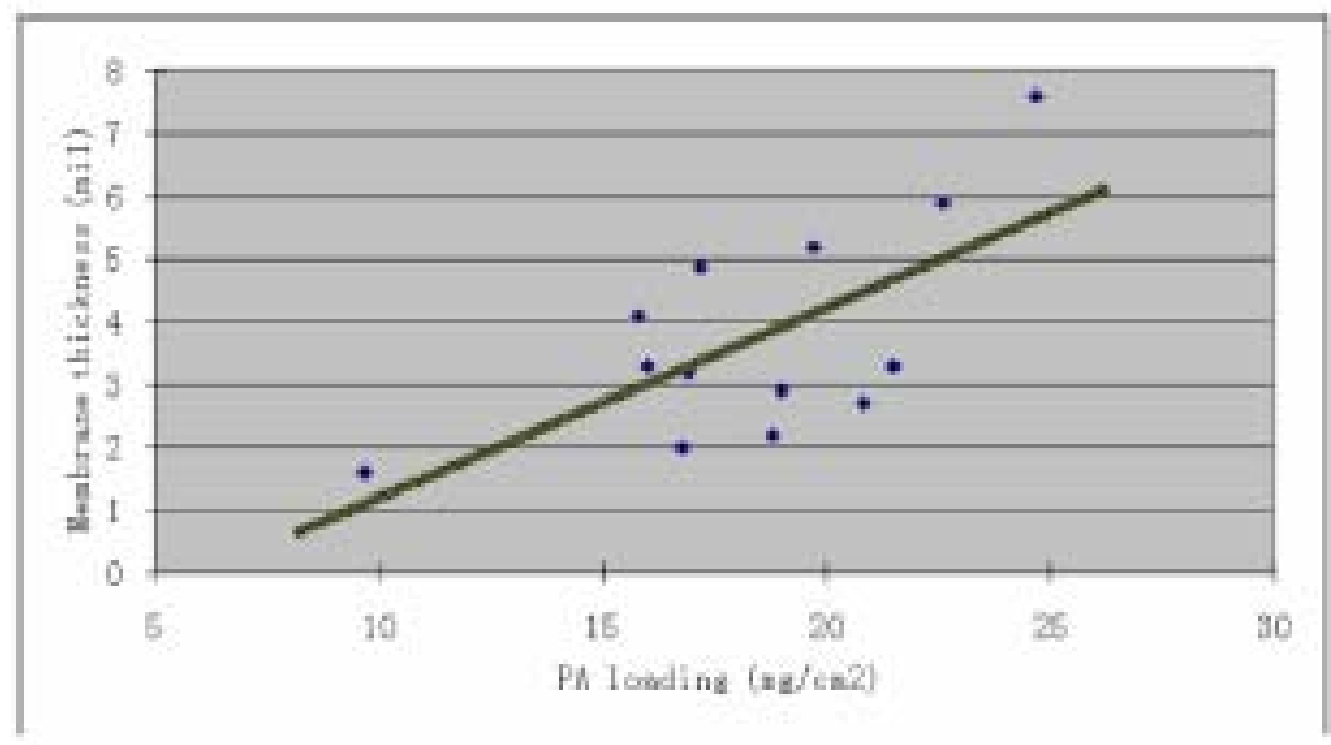

Figure 22: Correlation Between PA Loading and Membrane Thickness

Cell performance. The figure below (Figure 23) shows polarization curves taken throughout the lifetime test of 2500 hours at both $160^{\circ} \mathrm{C}$ and $180^{\circ} \mathrm{C}$. There was a 
significant difference between the 160 and $180^{\circ} \mathrm{C}$ data with the $180^{\circ} \mathrm{C}$ cell performance degrading faster with cell operation time. This is quantified in Figure 24. The cell performance degradation rate was $4.9 \mu \mathrm{V} / \mathrm{hr}$ and $17 \mu \mathrm{V} / \mathrm{hr}$ at $160^{\circ} \mathrm{C}$ and $180^{\circ} \mathrm{C}$, respectively. This correlation between cell performance degradation rates with cell operation temperatures can be explained by the general increase in all degradative processes (phosphoric acid loss/movement, electrode/catalyst degradation, etc) at the higher temperature.
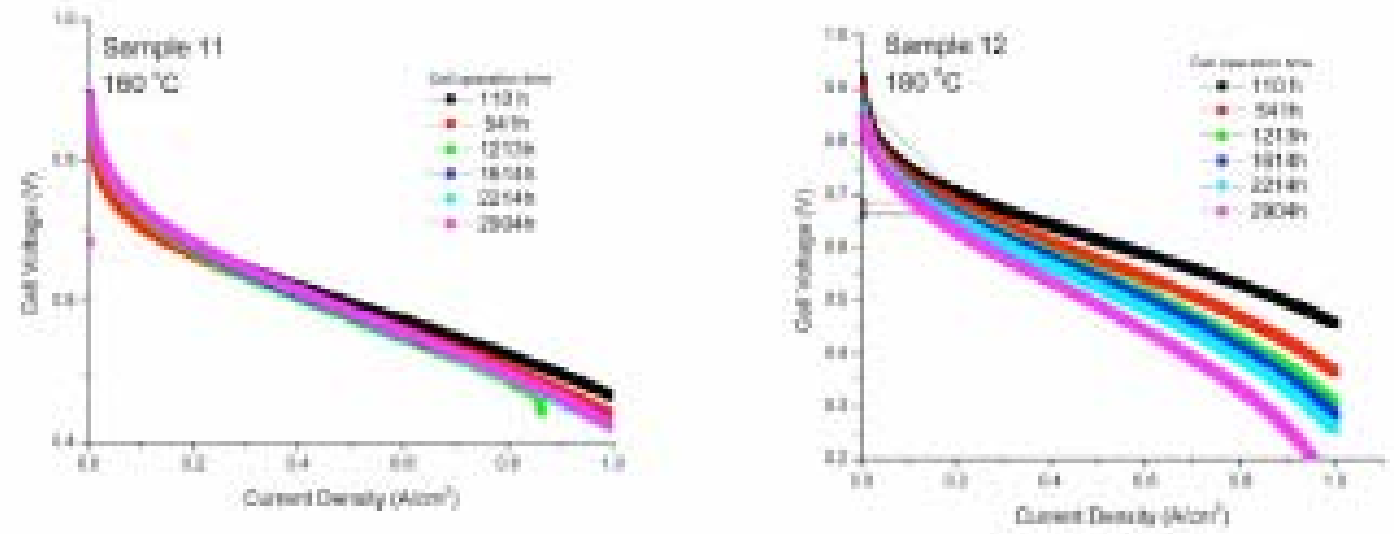

Figure 23: Polarization Curves Taken at $160^{\circ} \mathrm{C}$ (left) and $180^{\circ} \mathrm{C}$ (right) During 2500 Hour Operation

Polarization curves were taken at constant flow conditions, 1.2/2.0 stoic for hydrogen and air set at $1 \mathrm{~A} / \mathrm{cm} 2$.
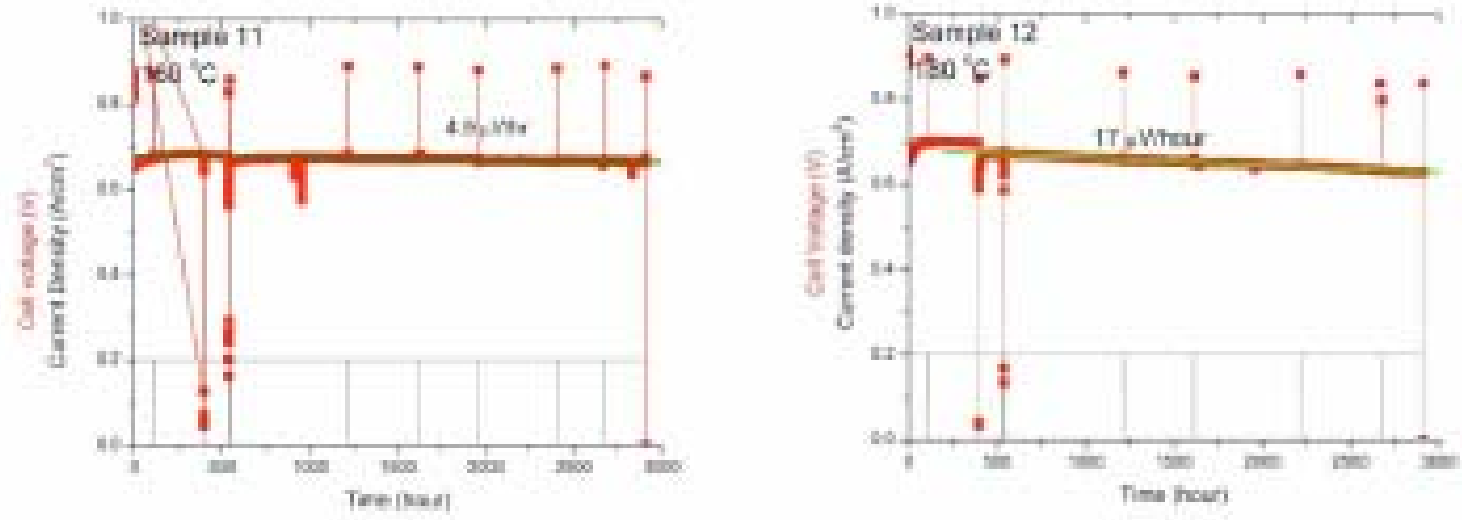

Figure 24: Cell Performance Degradation Rate at $160^{\circ} \mathrm{C}$ (left) and $180^{\circ} \mathrm{C}$ (right) During 2500 hour Operation

Cell performances were taken at $0.2 \mathrm{~A} / \mathrm{cm}^{2}, 1.2 / 2.0$ stoic for hydrogen and air. 
Phosphoric Acid in Exhaust Water. Phosphoric acid loss from the anode and cathode was collected and measured directly as described in the Experimental section. In Figure 25, the phosphoric acid loss rate (in the exhaust water) from both anode and cathode is plotted for both 160 and $180^{\circ} \mathrm{C}$ operation. The detailed data are included below in Table 8.
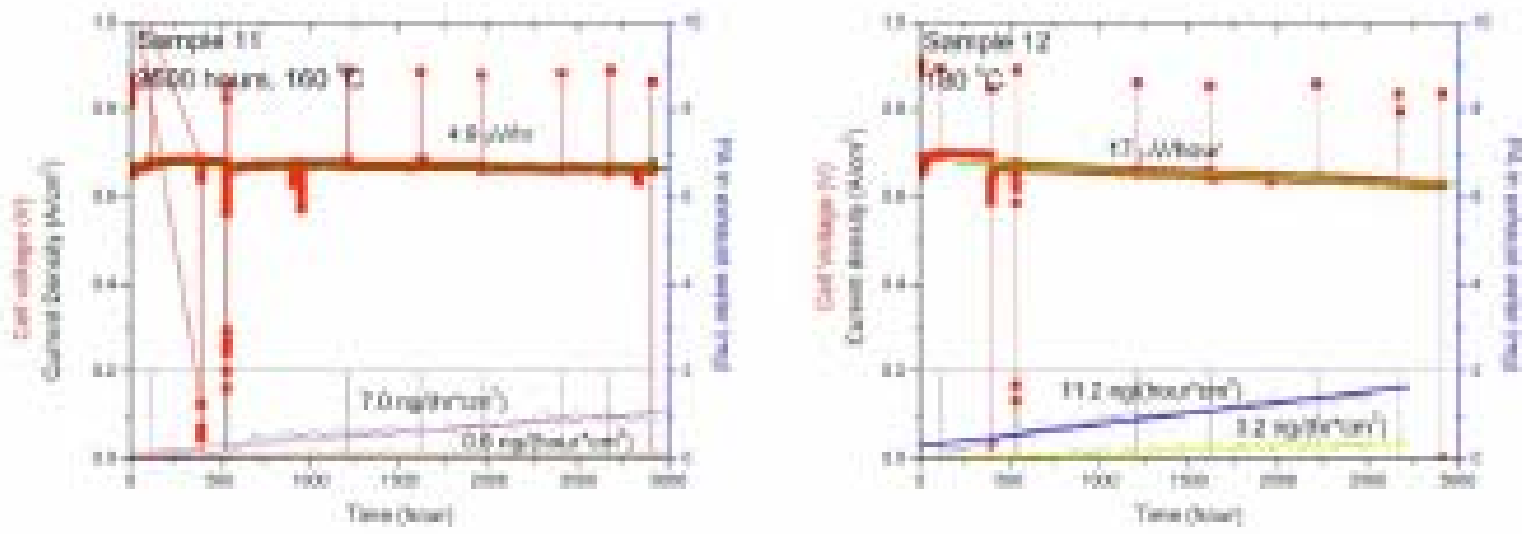

Figure 25: Phosphoric Acid in Exhaust Water at $160^{\circ} \mathrm{C}$ (left) and $180^{\circ} \mathrm{C}$ (right) During 2500 Hour Operation

\begin{tabular}{|l|l|c|c|}
\hline & & $\begin{array}{c}\text { Phosphoric acid loss rate } \\
(\text { nghricm }\end{array}$ & $\begin{array}{c}\text { Phosphoric acid loss } \\
(\mathrm{mg})\end{array}$ \\
\hline \multirow{2}{*}{ Sample 11 } & Anode & 0.6 & 0.08 \\
\cline { 2 - 4 } & Cathode & 7 & 0.9 \\
\hline \multirow{2}{*}{ Sample 12 } & Anode & 32 & 0.5 \\
\cline { 2 - 4 } & Cathode & 11.2 & 1.4 \\
\hline
\end{tabular}

Table 8: Phosphoric Acid Loss Rate and Total Phosphoric Acid Loss After 2500 Hours in the Exhaust Water

The phosphoric acid loss rate and total phosphoric acid loss in sample $12\left(180^{\circ} \mathrm{C}\right)$ was higher than sample $11\left(160^{\circ} \mathrm{C}\right)$. The higher vapor pressure of phosphoric acid at the higher temperature is the likely cause for the higher phosphoric acid lost rate.

\begin{tabular}{|c|c|c|c|c|}
\hline Sample & $\begin{array}{c}\text { PA in MEA } \\
\left(\mathrm{mg} / \mathrm{cm}^{2}\right)\end{array}$ & $\begin{array}{c}\text { Total PA in MEA } \\
(\mathrm{mg})\end{array}$ & $\begin{array}{c}\text { Total PA in } \\
\text { exhaust water } \\
(\mathrm{mg})\end{array}$ & $\begin{array}{c}\text { PA in flow plate } \\
(\mathrm{mg})\end{array}$ \\
\hline 0 & 24.7 & 1115 & 0 & 0 \\
\hline 11 & 16.8 & 759 & $0.08+0.9$ & 385 \\
\hline 12 & 9.7 & 438 & $0.5+1.4$ & \\
\hline
\end{tabular}

Table 9: PA Loss Distribution 
The total phosphoric acid in the reference MEA was calculated to be $1115 \mathrm{mg}$ (calculated from phosphoric acid loading multiplied by the MEA area- $-45.15 \mathrm{~cm}^{2}$ ). We assume all the samples were similar and had the initial phosphoric acid in the MEA of approximately $1100 \mathrm{mg}$.

After $2500 \mathrm{hrs}$ of cell operation at $160^{\circ} \mathrm{C}$, Sample $11 \mathrm{had} 759 \mathrm{mg}$ of phosphoric acid remaining in the MEA, so total phosphoric acid loss from the MEA was approximately $350 \mathrm{mg}$. For Sample $12\left(2500 \mathrm{hrs}\right.$ at $\left.180^{\circ} \mathrm{C}\right)$, the amount of phosphoric acid remaining in the MEA was $438 \mathrm{mg}$, so total phosphoric acid loss from the MEA was approximately $660 \mathrm{mg}$.

The total phosphoric acid collected in the exhaust water was 1.0mg (Sample 11, $0.08 \mathrm{mg}+0.9 \mathrm{mg}$ ); $1.9 \mathrm{mg}$ (Sample 12, $0.5 \mathrm{mg}+1.4 \mathrm{mg}$ ). Thus, the total phosphoric acid collected in the exhaust water for both samples was less than $1 \%$ of the total phosphoric acid loss from the MEA.

To account for the remaining phosphoric acid, the graphite flow plate from sample 11 was soaked in 1 liter of distilled water, and then the water was both titrated by $\mathrm{NaOH}$ and measured with ion chromatography for phosphoric acid. The results show that there was $385 \mathrm{mg}$ of phosphoric acid in the graphite flow plate. This amount agrees quite closely with the phosphoric acid lost from the MEA. We must then conclude that the flow plates are the major receptacle of phosphoric acid from the MEA.

Conclusions. By measuring the phosphoric acid content in the MEA, it was clearly shown that phosphoric acid loss/movement occurred during cell assembly, initial heatup and cell operation by mechanical pressing, and phosphoric acid evaporation. Initial heating on a closed cell was observed to be more severe than initial heating on an open cell. Significant thickness reductions of the membrane were observed - from 8 mils in the as-received MEA, to 5 mils after cell assembly, to 3 mils after the initial heating, to less than 2 mils after cell operation for more than 2500 hours. The thickness of the membrane had a roughly linear relationship with phosphoric acid content in MEA. The performance of the cell decreased as the cell operation time increased and higher cell operation temperature caused more severe cell performance degradation and a higher phosphoric acid loss rate. In long term cell operation, the phosphoric acid loss from the MEA was found to occur in the porous or micro porous graphite flow plates, while the phosphoric acid loss in the exhaust water accounted for less than $1 \%$ of the total loss.

\section{Load-cycling Tests}

Background and objective. The load cycling test is an effective accelerated test methodology to evaluate the fuel cell's durability. In this test, the cell performance degradation will be systematically explored through load cycle testing. 
Design of experiments. During the design of experiments, three variables were considered: cathode catalyst, cell operation temperature, and fuel relative humidity. A total of eight samples were tested as shown below.

\begin{tabular}{|c|c|c|c|}
\hline Sample & Cathode catalyst & $\begin{array}{c}\text { Cel operation } \\
\text { temperature }\end{array}$ & Fuel humidty \\
\hline 1 & PUC & $160^{\circ} \mathrm{C}$ & Humidified \\
\hline 2 & PUC & $160^{\circ} \mathrm{C}$ & Dry \\
\hline 3 & PUC & $180^{\circ} \mathrm{C}$ & Humidified \\
\hline 4 & PUC & $180^{\circ} \mathrm{C}$ & Dry \\
\hline 5 & Pt Alloy/C & $160^{\circ} \mathrm{C}$ & Humidified \\
\hline 6 & Pt Alloy/C & $160^{\circ} \mathrm{C}$ & Dry \\
\hline 7 & Pt Alloy/C & $160^{\circ} \mathrm{C}$ & Humidified \\
\hline 8 & Pt Alloy/C & $180^{\circ} \mathrm{C}$ & Dry \\
\hline
\end{tabular}

Table 10: Experimental Design

Experimental. Samples 1 to 4 used commercial MEAs (PEMEAS, Celtec-P) and samples 5 to 8 used commercial MEAs (PEMEAS, Celtec-P 1000). All the samples were tested on the Fuel Cell Technologies' fuel cell test system. The fuel humidity was controlled at $60^{\circ} \mathrm{C}$ dew point. The load cycle test protocol was: hold at OCV for 2 minutes, then hold at $0.2 \mathrm{~A} / \mathrm{cm} 2$ for 30 minutes and $0.6 \mathrm{~A} / \mathrm{cm} 2$ for another 30 minutes. The gas flow rates were 1.2/2.0 stoic for hydrogen and air at atmospheric pressure. Each sample was initially run at $0.2 \mathrm{~A} / \mathrm{cm} 2,180^{\circ} \mathrm{C}$ and $1.2 / 2.0$ stoic for hydrogen and air for 100 hours and then tested for at least 500 cycles as per the above test protocol.

\section{Results and Discussion}
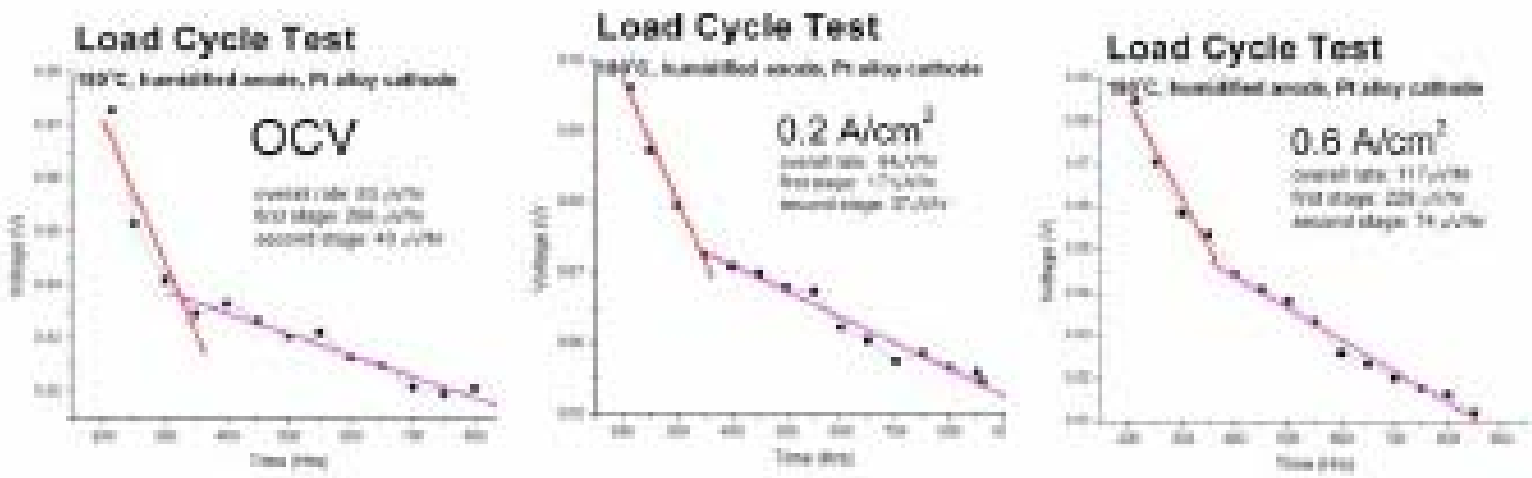

Figure 26: Example of Cell Performance Degradation in Load Cycle Test (Sample 7)

(a), (b) and (c) are cell performance at OCV, $0.2 \mathrm{~A} / \mathrm{cm} 2$ and $0.6 \mathrm{~A} / \mathrm{cm} 2$, respectively with time. The cell's performance degradation was observed during the entire range of 
testing. In all of the testing there were two distinct stages of degradation with different degradation rates. Most of cell performance change occurred during Stage I (approximately the first 150 hours of cell load cycle testing). After this initial Stage, the performance degradation rate decreased.

The cell performance degradation rate was lower when the fuel was humidified, especially when cell operated at higher temperature. This was observed at $0.2 \mathrm{~A} / \mathrm{cm} 2$, $0.6 \mathrm{~A} / \mathrm{cm} 2$, and at $\mathrm{OCV}$. Cells operated at $180^{\circ} \mathrm{C}$ had higher cell performance but also had higher degradation rates as compared to the cells operated at $160^{\circ} \mathrm{C}$. Cells with pure $\mathrm{Pt}$ cathode catalyst had higher long term load cycling stability although their performance was lower than the cells with Pt alloy cathode.

\begin{tabular}{|c|c|c|c|c|c|c|c|c|c|}
\hline \multirow{3}{*}{ Sample } & \multirow{2}{*}{\multicolumn{3}{|c|}{ Running Conditions }} & \multicolumn{6}{|c|}{ Cell Voltage Degradation rate (mV/hr) } \\
\hline & & & & \multicolumn{2}{|c|}{$0.2{\mathrm{~A} / \mathrm{cm}^{2}}^{2}$} & \multicolumn{2}{|c|}{$0.6 \mathrm{~A} / \mathrm{cm}^{2}$} & \multicolumn{2}{|c|}{$\mathrm{OCV}$} \\
\hline & Temp & Humidity & Catalyst & first & second & first & second & first & second \\
\hline 1 & $160^{\circ} \mathrm{C}$ & Humldined & Ptic & 59 & 18 & 80 & 19 & \multicolumn{2}{|r|}{28} \\
\hline 2 & $160^{\circ} \mathrm{C}$ & dry & Ptic & 210 & 17 & 412 & 17 & 249 & 51 \\
\hline 3 & $180^{\circ} \mathrm{C}$ & Humidined & Ptic & 108 & 17 & 200 & 38 & 298 & 54 \\
\hline 4 & $180^{\circ} \mathrm{C}$ & dry & Ptic & 247 & 76 & 339 & 145 & & 193 \\
\hline 5 & $160^{\prime} \mathrm{C}$ & Humidined & Pt Alloy/C & \multicolumn{2}{|c|}{54} & \multicolumn{2}{|c|}{91} & \multicolumn{2}{|r|}{72} \\
\hline 6 & $160^{\circ} \mathrm{C}$ & dry & Pt Alloy/C & 123 & 49 & 263 & 98 & 190 & 49 \\
\hline 7 & $180^{\circ} \mathrm{C}$ & Humldined & Pt Alloy/C & 171 & 37 & 228 & 74 & 266 & 40 \\
\hline 8 & $180^{\circ} \mathrm{C}$ & $d r y$ & Pt Alloy/C & 251 & 60 & 346 & 107 & 228 & 59 \\
\hline
\end{tabular}

Table 11: Cell Performance Degradation Rate in Load Cycle Tests

Conclusions. In load cycle tests, the performance degradation showed two stagesan initial performance drop at higher rates followed by a second stage with lower degradation rates. The fuel relative humidity lowered the performance degradation rate. The cells with Pt alloy cathode had higher performance but higher degradation rates compared to the cells with pure platinum cathode.

\section{Startup/shutdown Cycling Tests}

Background and objective. During the cell startup/shutdown cycle, the cell may experience voltages larger than $0.8 \mathrm{~V}$, which may effect the fuel cell's performance degradation and long term stability. Cells operating at voltages larger than $0.8 \mathrm{~V}$ may experience corrosion of the catalyst support materials - carbon. The corrosion of carbon may reduce the catalyst's active electrochemical surface area, and increase the resistance of electron and mass transport. In addition, voltages larger than $0.8 \mathrm{~V}$ may corrode the electrocatalyst - nano size Pt particles. The dissolution of Pt particles due to Ostwald ripening is higher at cell potentials larger than $0.8 \mathrm{~V}$. 
There are many different protocols for start-up/shut-down testing. In this research, a startup/shutdown profile will be developed to reduce the time that the cell voltage is larger than $0.8 \mathrm{~V}$. Also, the effect of cell voltage greater than $0.8 \mathrm{~V}$ on the cell's performance degradation is explored.

\section{Design of Experiments.}

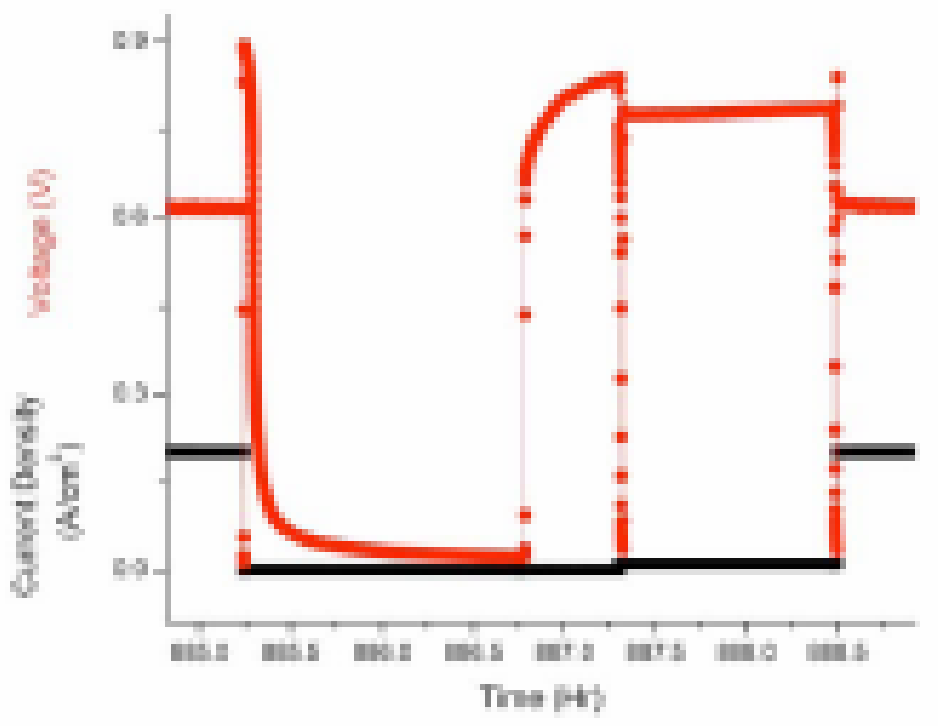

Figure 27: A Typical Cell Shutdown/startup Cycle According to the RPI Protocol

A portion of the typical RPI fuel cell shutdown/startup cycle is shown in Figure 27 . The shutdown process started by changing the load to $0.0 \mathrm{~A} / \mathrm{cm} 2(\mathrm{OCV})$ and reducing the gases to the minimum flow rates (anode: $\mathrm{H} 2,50 \mathrm{ml} / \mathrm{min}$; cathode: air $83 \mathrm{ml} / \mathrm{min}$ ) for one minute to remove residual product water from the cell, and then the fuel cell was cooled to $55^{\circ} \mathrm{C}$ without any gas flow. The subsequent startup process began by heating the fuel cell from $55^{\circ} \mathrm{C}$ to $120^{\circ} \mathrm{C}$ at $\mathrm{OCV}$ with minimum gas flow rates (same as above), then the fuel cell temperature was raised to $180^{\circ} \mathrm{C}$ at constant current density $(0.01 \mathrm{~A} / \mathrm{cm} 2)$ with the minimum flow rates.

Once the cell temperature reached $180^{\circ} \mathrm{C}$, the fuel cell was operated for 3 hours at 0.2 $\mathrm{A} / \mathrm{cm} 2$ with hydrogen.$(=1.2,75 \mathrm{ml} / \mathrm{min})$ and air $(=2.0,301 \mathrm{ml} / \mathrm{min})$ before starting the next cycle. The cell's voltage drops quickly when the cell is initially shut down. Thus, the time that the cell voltage was larger than $0.8 \mathrm{~V}$ was very small during the shut down. However, the time that the cell voltage was larger than $0.8 \mathrm{~V}$ during startup/shutdown cycle mainly occurs during the cell startup phase. 


\begin{tabular}{|c|c|c|c|c|c|}
\hline Sample & 1 & 2 & 3 & 4 & 5 \\
\hline Gases supply from & $30^{\circ} \mathrm{C}$ & $56^{\prime} \mathrm{C}$ & $80^{\circ} \mathrm{C}$ & $100^{\circ} \mathrm{C}$ & $120^{\prime} \mathrm{C}$ \\
\hline
\end{tabular}

Table 12: Design of Experiments (I)

A series of experiments were designed to explore the effects of temperature at which gases were supplied to the cell during heatup, with the time that the cell experienced OCV conditions (Table 12).

Another series of experiments (Table 13) were designed to explore the effect of the time the cell remained at OCV on the cell performance degradation during the startup/shutdown cycle test.

\begin{tabular}{|c|c|}
\hline Sample & OCV time (hours) per cycle \\
\hline A & 3 \\
\hline$B$ & 2 \\
\hline C & 1 \\
\hline D & D (few mins) \\
\hline
\end{tabular}

Table 13: Design of Experiments (II)

For Samples A, B, and C, the shutdown/startup cycle was conducted as follows: First, the shutdown process started by changing the load to $0.0 \mathrm{~A} / \mathrm{cm} 2(\mathrm{OCV})$ and setting the gases to the minimum flow rates (see above) for one minute to remove the residual product water from the cell, and then the cell was cooled to $30^{\circ} \mathrm{C}$ and held at that temperature for 1 hour without supplying any gases. Then, the startup process began by heating the fuel cell from $30^{\circ} \mathrm{C}$ to $180^{\circ} \mathrm{C}$ with minimum gas flow rates (see above).

The heatup required approximately 1 hour, and during the heatup, the load on the fuel cell was set to $0.0 \mathrm{~A} / \mathrm{cm} 2(\mathrm{OCV})$. Once the fuel cell temperature reached $180^{\circ} \mathrm{C}$, the fuel cell was held at OCV and $180^{\circ} \mathrm{C}$ for the designed time (Sample A, 2 hours: Sample B, 1 hour; Sample C, 1 minute). Thus, the total OCV time per cycle of Samples A, B, and C was 3,2 , and 1 hours, respectively.

After the hold time at OCV, the fuel cell was operated for 3 hours at $0.2 \mathrm{~A} / \mathrm{cm} 2$ with hydrogen $(=1.2,75 \mathrm{ml} / \mathrm{min}$, and air.$(=2.0,301 \mathrm{ml} / \mathrm{min})$ before starting the next cycle. For Sample D, the shutdown process was the same as the other samples, but the startup process was different. The fuel cell was heated from $30^{\circ} \mathrm{C}$ to $180^{\circ} \mathrm{C}$ without gases supplied. Once the fuel cell temperature reached $180^{\circ} \mathrm{C}$, the cell was supplied with gases at the minimum flow rates (see above) and the load on the fuel cell was set to $0.0 \mathrm{~A} / \mathrm{cm} 2(\mathrm{OCV})$ for 2 minutes. After 2 minutes holding at $\mathrm{OCV}$, the fuel cell was 
operated for 3 hours at $0.2 \mathrm{~A} / \mathrm{cm} 2$ with hydrogen $(=1.2,75 \mathrm{ml} / \mathrm{min})$ and air $(=2.0,301$ $\mathrm{ml} / \mathrm{min}$ ) before starting the next cycle.

Experimental. Commercial MEAs (PEMEAS, Celtec-P 1000) were used in all tests. All the samples are tested on the Fuel Cell Technologies' fuel cell test system. The sample break-in protocol was 100 hours at $0.2 \mathrm{~A} / \mathrm{cm} 2,180^{\circ} \mathrm{C}$, and $1.2 / 2.0$ stoic for hydrogen and air.

\section{Results and Discussion}

Time at OCV during startup/shutdown cycles. Due to the thermal mass and limitations of the pad heaters and insulation, the cells require between 30 and 60 minutes to heat to the operating temperature. Thus, the point at which gases are supplied to the cell during this time effects the time that the cell experiences OCV conditions. In this work, a linear relationship was shown between the temperatures at which gases were supplied to the cell and with time of cell experience OCV conditions (Figure 28). Thus, the time that the cell remained at OCV during the heat up cycle can be closely controlled by the cell temperature at which the gases are supplied to the cell. This provides a fairly simple operational method to limit degradation caused by OCV conditions.

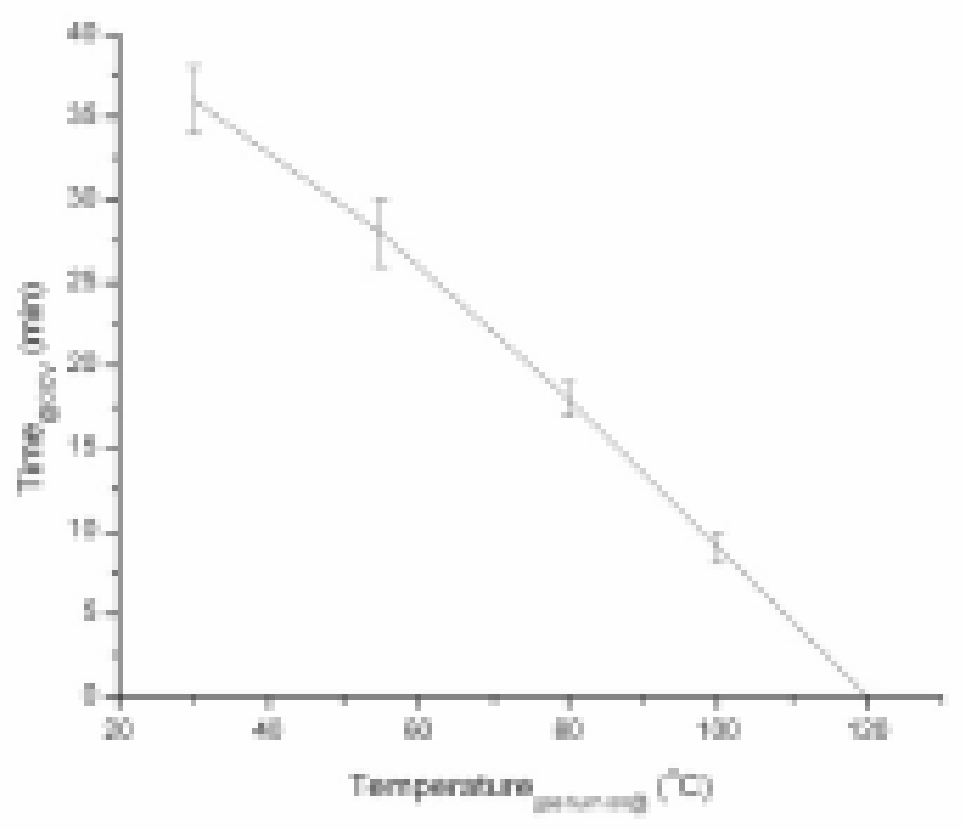

Figure 28: Time of Cell at OCV During Startup/shutdown Cycle

Cycling effects on cell performance degradation. Three different plots are shown in Figure 29. The cell's performance (cell voltage when current density was $0.2 \mathrm{~A} / \mathrm{cm} 2$ ) is 
plotted against cell operation time, time of cell at OCV, and number of cell startup/shutdown cycles.
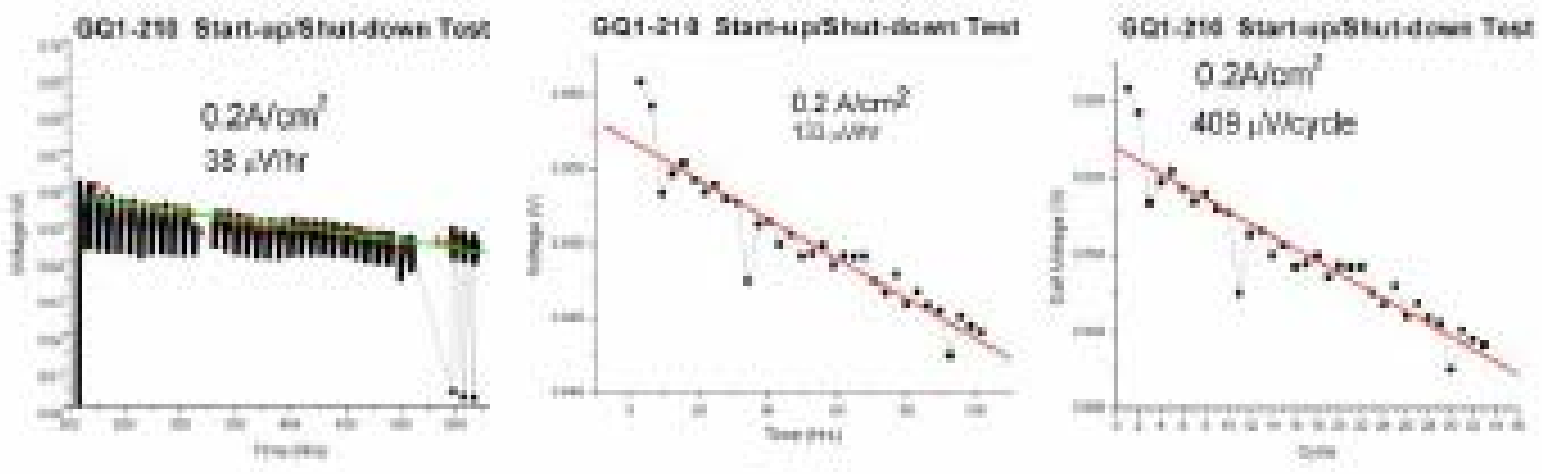

Figure 29: Examples of Cell Performance Degradation During Startup/shutdown Cycle Testing (Sample A):

(a) Cell Voltage vs. Cell Operation Time

(b) Cell Voltage vs. Time of Cell @OCV

(c) Cell Voltage vs. Number of Cell Startup/shutdown Cycles

\begin{tabular}{|c|c|c|c|c|}
\hline Sample & $\begin{array}{l}\text { Time (hrs) } \\
\text { (Cell at OCV } \\
\text { Per cycle) }\end{array}$ & $\begin{array}{c}\text { Degradation Rate } \\
\text { (Cell cycle) } \\
\text { («Woycle) }\end{array}$ & $\begin{array}{c}\text { Degradation Rate } \\
\text { (Cell operation time) } \\
(\mu \mathrm{Wr})\end{array}$ & $\begin{array}{c}\text { Degradation Rate } \\
\text { (Time of Cell at } \\
\text { OCV) } \\
\text { (uVhr) }\end{array}$ \\
\hline A & 3 & 409 & 38 & 133 \\
\hline $\mathrm{B}$ & $\frac{2}{2}$ & 394 & 34 & 283 \\
\hline $\mathrm{C}$ & 1 & 307 & 31 & 299 \\
\hline $\bar{D}$ & $0(\mathrm{Few}$ enules) & 907 & 91 & 1 \\
\hline
\end{tabular}

Table 14: Cell Performance Degradation in Startup/shutdown Cycle Tests

All the cell performance degradation rates are shown in Table 14. Samples that had longer OCV times per cycle had larger performance degradation rates compared to samples which had shorter OCV times per cycle when the cell voltages (current density is $0.2 \mathrm{~A} / \mathrm{cm} 2$ ) were plotted with number of cell startup/shutdown cycle or cell operation time (except sample D, which will be discussed later).

When cell voltages (current density was $0.2 \mathrm{~A} / \mathrm{cm} 2$ ) are examined as a function of the time that the cell remained at OCV, the data showed a different trend in cell performance degradation rate as compared to cell voltages examined as a function of the number of cell startup/shutdown cycle or cell operation time. This apparent contradiction can be explained from the variation in the time of the experiment. As the 
time at OCV per cycle is decreased, the overall time in a cycle is decreased and the number of cycles in a set amount of time increases. Thus, samples which have shorter OCV times per cycle have more startup/shutdown cycles than samples which have longer OCV time per cycle. Therefore, the data suggests that the effects (which may be thermal stress on the MEA, cell parts, etc.) caused by more startup/shutdown cycles have a strong impact on cell performance degradation that may be equal to or greater than the effects of the cell remaining at OCV. These two effects are linked and are not considered as independent variables in this set of experiments, but the effects of more cycles can be seen in the data.

Sample $\mathrm{D}$ shows different behavior as compared to other three samples. With the very short OCV time per cycle, one might predict a lower degradation rate when the cell voltage is plotted with cell cycle and cell operation time as was done for Samples A, B and $\mathrm{C}$. However, the cell performance degradation rate was two to three times higher than Samples A, B and C. However, we assign the major difference to the test protocol. To achieve a near-zero time of the cell at OCV during the startup/shutdown cycle, the gases were not supplied during the cell startup. This situation was similar to the tests described above, i.e., a closed and heated system, which we have subsequently found will cause more severe phosphoric acid loss/movement and performance degradation. This effect was not known at the time the team planned and began the experiments, but is consistent with earlier work.

Conclusions. Time of cell @ OCV in the startup/shutdown cycle can be exactly controlled by the temperature at which the gases start to supply. The cell staying at OCV causes the cell performance degradation. However, the effects (thermal stress on MEA, cell parts, etc.) caused by startup/shutdown cycle have more strong impact on cell performance degradation, time of cell staying at OCV shows a secondary effect compared to the number of startup/shutdown cycles.

Plug Power confirmation of RPI and BASF testing. Plug Power labs confirmed BASF and RPI trends; based on the results of approximately 3000 hours of testing at 160 and $180 \mathrm{C}$ cell operating temperatures. There was no statistically significant difference in decay rate between dynamic load and static load operations. However, all cells showed much higher (3-10 times) decay rates than those demonstrated by BASF or RPI. See Figures 30 and 31 and summary Tables 15 and 16 below. 
Cell 3208 - Constant Current Density at $0.2 \mathrm{Akm^{2 }}$

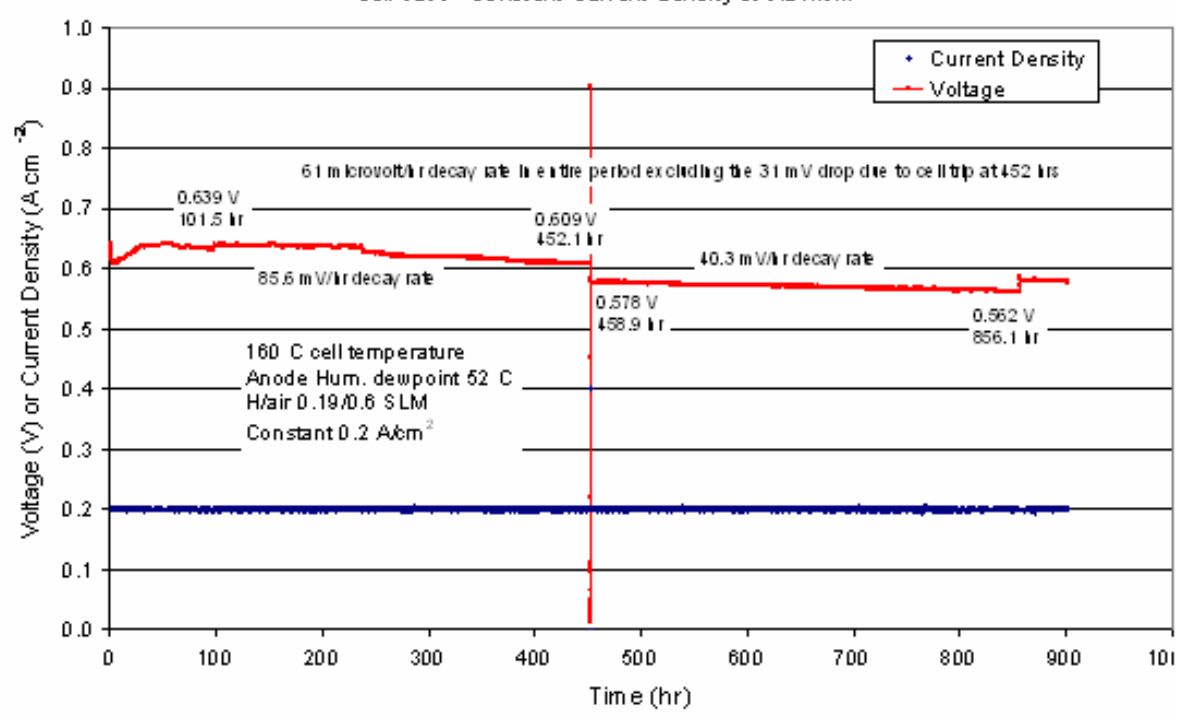

Figure 30: Example of Plug Power Steady State Operation at $160 \mathrm{C}-0.2 \mathrm{~A} / \mathrm{cm}^{2}$

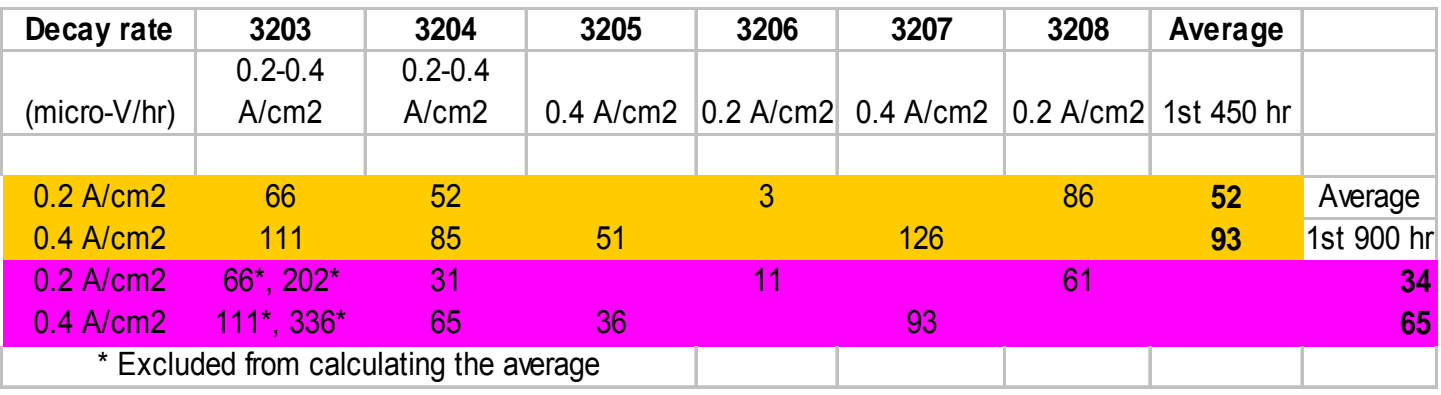

Table 15: Summary of Data 


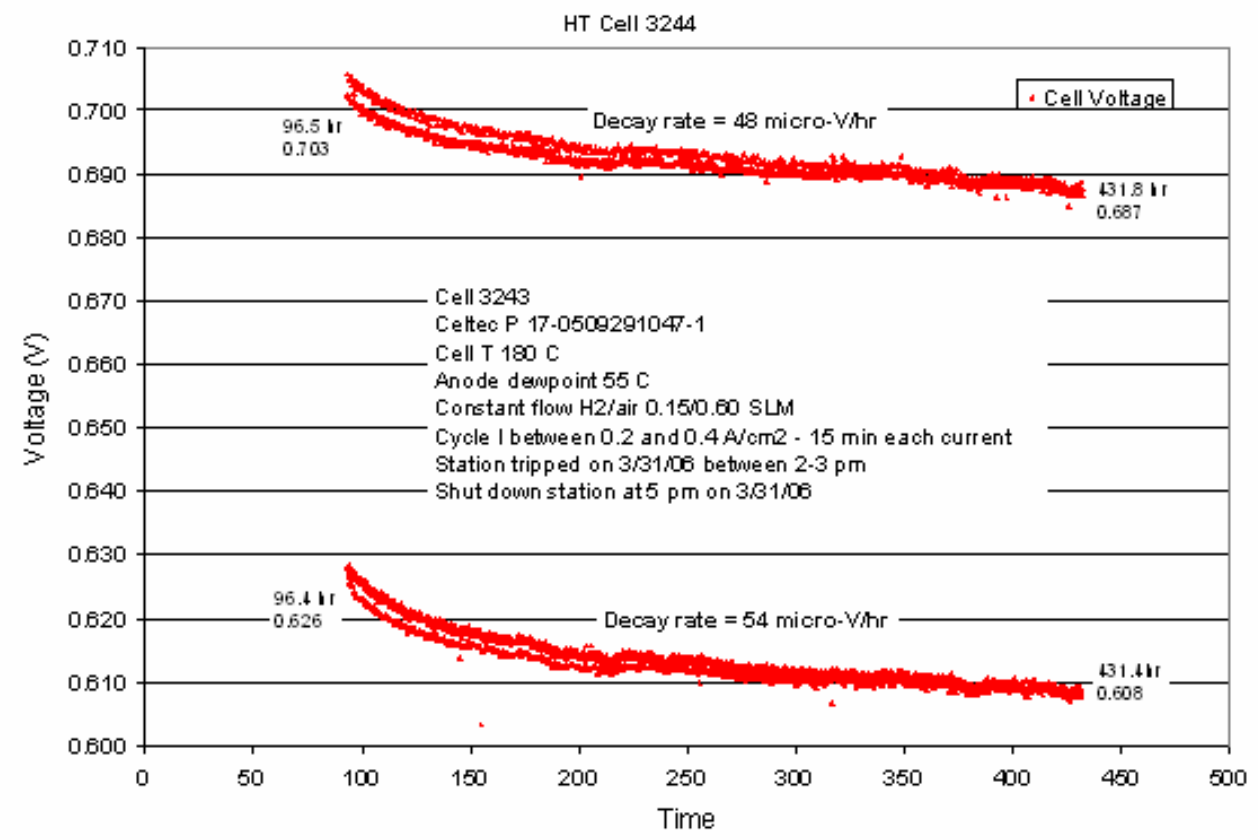

Figure 31: Example of Plug Power Load Cycling at $180 \mathrm{C}-0.2-0.4 \mathrm{~A} / \mathrm{cm}^{2}$

\begin{tabular}{|l|c|c|c|c|c|c|c|}
\hline Decay Rate & 3240 & 3241 & 3242 & 3243 & 3244 & 3245 & Average \\
\hline (micro-V/hr) & & & & & & & \\
\hline 0.2 A/cm2 & 60 & & 30 & & 48 & 39 & 44 \\
\hline 0.4 A/cm2 & & 70 & & 62 & 54 & 48 & 59 \\
\hline
\end{tabular}

Table 16: Summary of Data

A major effort was undertaken by the team to investigate the discrepancy between Plug Power and BASF/RPI results.

Investigation of decay rate discrepancy. For the recent testing of the developmental MEAs Plug Power observed decay rates $\sim 30 \mu \mathrm{V} / \mathrm{Hr}$ on 3,000 hour scale. This degradation rate led to relatively short cell lifetimes of several thousand hours compared with BASF's and RPI's > 10,000 hr standard observations.

BASF and RPI have demonstrated $<10 \mu \mathrm{V} / \mathrm{hr}$, H2/air, dry, steady state, 20,000 and $14,000 \mathrm{hrs}$, respectively, $>6,000 \mathrm{hrs}$ load cycling with a projected 14,000 hrs life, and 110 start-up/shut-down cycles. 

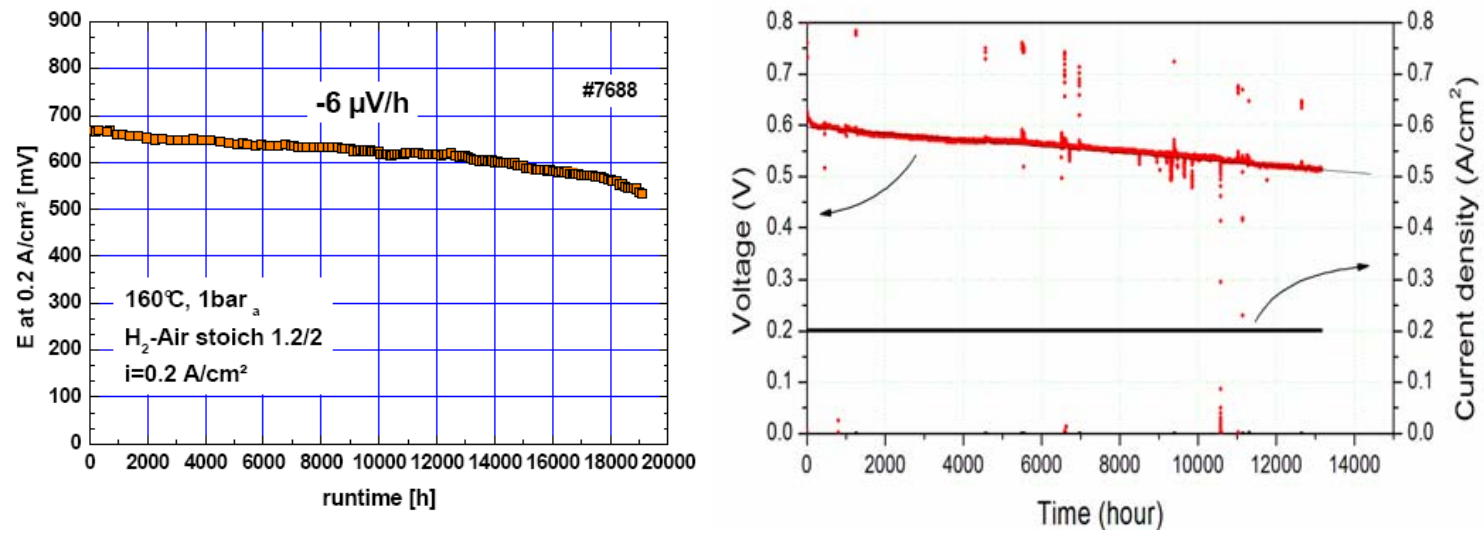

Figure 32: Typical BASF and RPI MEA Performance Data

BASF supplied Plug Power with a statistical analysis of their MEA's performance based on a maximum expected performance and a minimal acceptable performance. Any cell performing below the minimal acceptable should be assumed to be either assembled incorrectly or to have a faulty MEA.

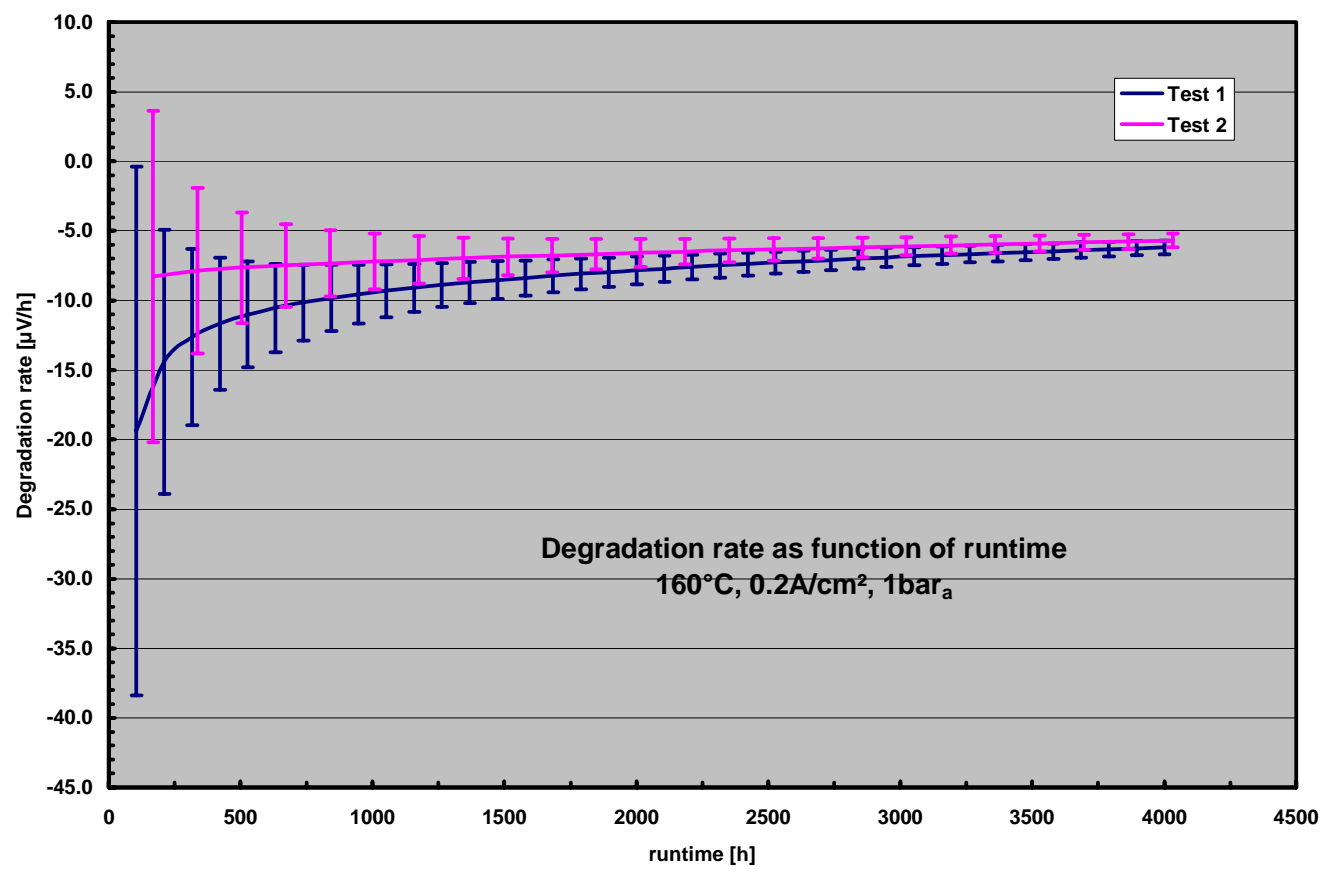

Figure 33: Statistical Distribution of BASF MEAs

This information was critical to Plug Power's investigation in that it gave a baseline and range over which nominal performance could be assumed.

The investigation of the discrepancy began with a review of the standard failure modes of PBI MEAs: 
- Catalyst sintering and dissolution

- Catalyst support corrosion

o Including carbon in the micro-porous layers

- Acid loss/redistribution

o Acid loss from MEAs high but to outside cell low

- A large portion of acid moves to plates from MEAs

- Membrane thinning/creeping

o Expect worsened by acid loss from MEAs

All above failure modes are accelerated at 180 vs. $160 \mathrm{C}$.

An intense analysis of the differences in how Plug Power and BASF operate was conducted focused on cell hardware, assembly, and testing. The strategy pursued was to build cells at both Plug Power and BASF/RPI and cross test them at both locations.

Examples of some of the differences between the labs are as follows:

\begin{tabular}{|c|c|c|c|}
\hline \multicolumn{4}{|c|}{ Hardware } \\
\hline Items & Plug & RPI/PEMEAS & Proposed Actions \\
\hline $\begin{array}{l}\text { Gas in/out holes } \\
\text { on plates }\end{array}$ & Smaller & Larger & $\begin{array}{l}\text { Change to } \\
\text { RPI/PEMEAS design }\end{array}$ \\
\hline Current collectors & Corroded & Uncorroded & Redo gold coating \\
\hline Current collectors & Mixed & $\begin{array}{l}\text { Separted V } \\
\text { and I pins }\end{array}$ & Change to PEMEAS \\
\hline O-rings & Reuse & Dispose & Dispose \\
\hline $\begin{array}{l}\text { Teflon tape on } \\
\text { fittings }\end{array}$ & $\begin{array}{l}\text { Rarely } \\
\text { change }\end{array}$ & $\begin{array}{l}\text { Change } \\
\text { everytime }\end{array}$ & Change everytime \\
\hline Bevel Washers & Reuse & Dispose & Dispose \\
\hline Plate cleaning & $\begin{array}{l}\text { Boiling to } \\
\text { Sonicating }\end{array}$ & Boiling & Change to boiling \\
\hline
\end{tabular}

Table 17: Cell Hardware Differences Between BASF and Plug Power 


\begin{tabular}{|l|l|l|l|}
\hline \multicolumn{4}{|c|}{ Cell Assembly Process } \\
\hline Items & Plug & RPI/PEMEAS & Actions Taken \\
\hline $\begin{array}{l}\text { Pre-compression } \\
\text { DC resistance } \\
\text { measurement }\end{array}$ & Yes & No & $\begin{array}{l}\text { Abandon (Au-coated } \\
\text { plates corroded) }\end{array}$ \\
\hline Alignment pins & $\begin{array}{l}\text { Different } \\
\text { sizes }\end{array}$ & One size & Change to one size \\
\hline Alignment holes & $\begin{array}{l}\text { Use one } \\
\text { template }\end{array}$ & Use gasket itself & Follow PEMEAS \\
\hline Bolt torque & $\begin{array}{l}30 \text { in-lbs } \\
\text { one time } \\
\text { without } \\
\text { waiting }\end{array}$ & $\begin{array}{l}\text { 15 in-lbs, wait for } \\
\text { minutes, then 30 } \\
\text { in-lbs, check } \\
\text { leakage, if leaks, } \\
\text { to 45 in-lbs } \\
\text { maximum }\end{array}$ & Follow PEMEAS \\
\hline
\end{tabular}

Table 18: Cell Assembly Differences Between BASF and Plug Power

In summary; sources of differences were discovered and rectified. Ultimately, lab-to-lab correlation between Plug Power and BASF/RPI was achieved on a statistically significant basis. Interestingly, this required an organizational mindset change from Nafion to PBI. That is, technician and lab handling procedures, methods of measurement and analysis and operation had to take into account PBI and its properties vs. Nafion.

Development of Approaches to Higher Durability. This investigation led to a more complete understanding of the critical parameters of MEA performance and degradation. This understanding confirmed or introduced several approaches to higher MEA durability:

- MEA Robustness Improvements

o Change to graphitic carbon catalyst-support and micro-porous layer

o Use Pt alloys as catalyst

o Increase PBI content and reduce low MW PBI

- Cell/stack Optimization

o Flow-fields and manifolds for PBI properties

o Plates

- Oxidative stability and porosity of non-graphitic materials 
- MEA/plate compression tolerance optimization

- Improve sealing/bonding to prevent edge failure and cooler bowing

- Pre-condition stack components to reduce acid loss from MEAs

- Optimization of fuel cell operation

Figure 34 shows the BOL performance characterization that correlates well with BASF data. The testing was conducted with $\mathrm{H} 2 /$ air and on $45 \mathrm{~cm}^{2}$ cells. It compares 16 tests at Plug Power with approximately 120 samples at BASF. While there is a small $(<3 \%)$ lower average performance in Plug Power testing, there is no statistically significant difference in the measurements.

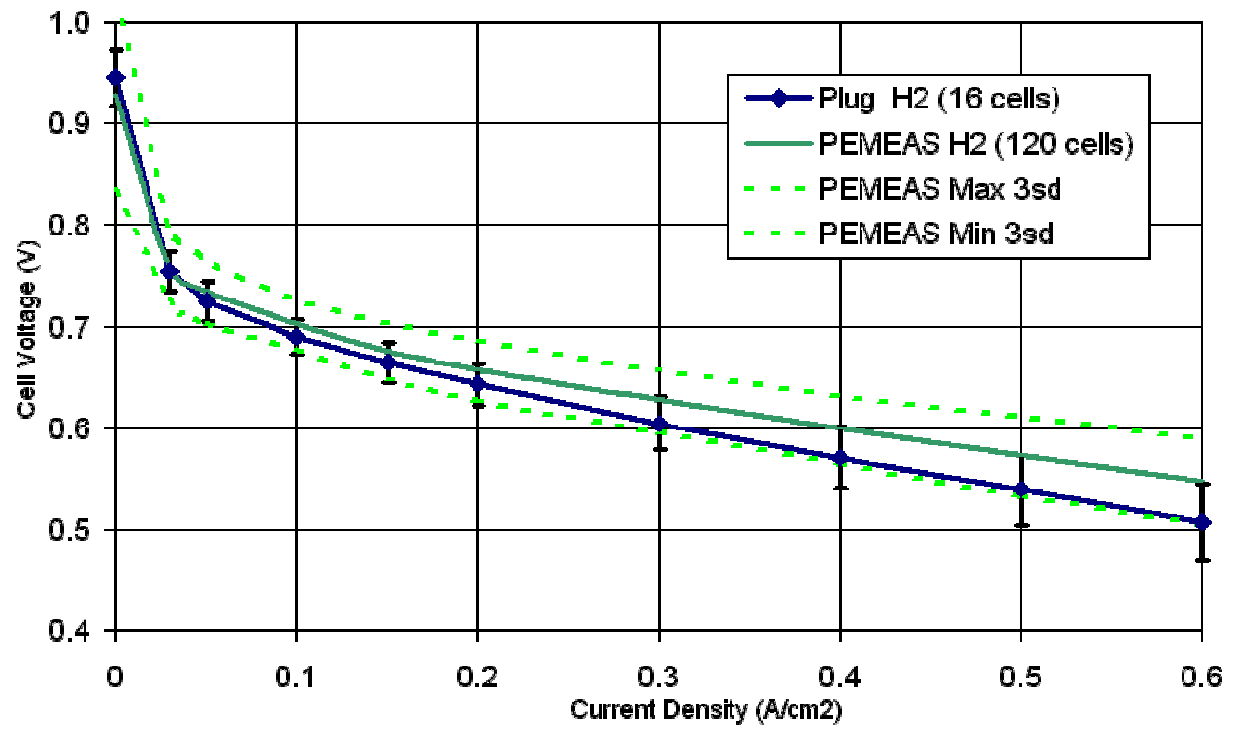

Figure 34: BOL MEA H2 Performance Comparison

The small difference was investigated and determined to be caused by slightly higher impedance in Plug Power's plate material.

The next step was a similar characterization on reformate. Figure 35 shows the results of this characterization which is slightly lower $(<10 \mathrm{mV})$ than expectations. The cause for this lower performance was determined to be an unexpected sensitivity to $\mathrm{CO}$ as a function of operating temperature. This phenomena was explored and it was determined that operating the MEA at $180 \mathrm{C}$ as opposed to $160 \mathrm{C}$, with the potential for slightly higher susceptibility to MEA failure modes (carbon corrosion, catalyst oxidation, etc.) was desirable because of the performance gain while operating on reformate with $\mathrm{CO}$. 
Further testing showed a significant tapering off of performance gain as a function of temperature past $180 \mathrm{C}$. At this time, we do not believe it is worth the performance tradeoff with the increased susceptibility above this temperature.

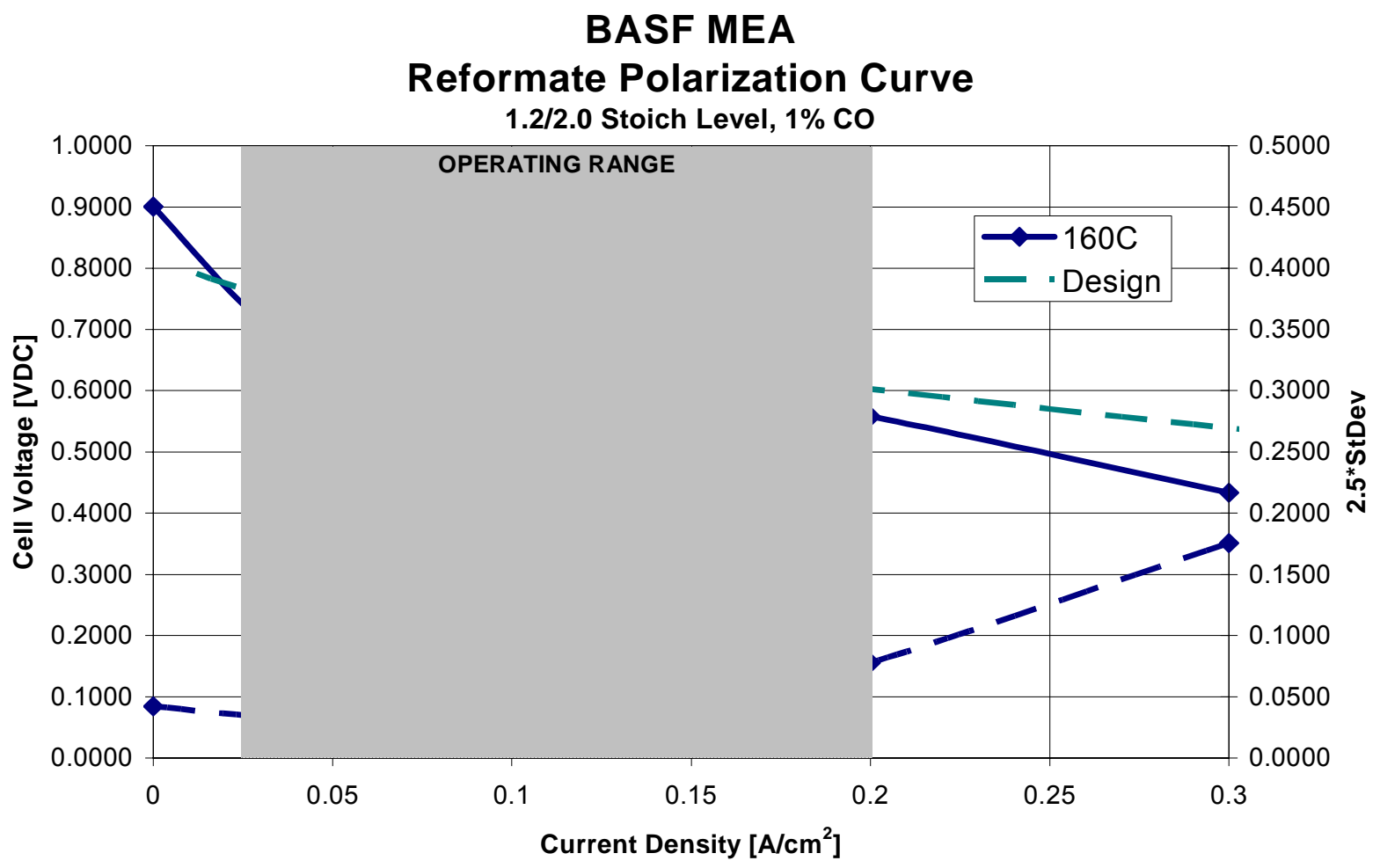

Figure 35: BOL MEA Reformate Performance

Along with characterization, issues related to scale up of the MEA technology were investigated. Central to this was the autopsy results obtained from Module 003 . This module is a 16 cell short stack containing scaled-up BASF MEAs and hardware: plates, flowfields, manifolds, gaskets, endplates, insulator coatings and collectors; developed under this program. As previously reported, this short stack ran for over 7200 hours on dry H2/air during its endurance test. Cell spread increased from $20 \mathrm{mV}$ at BOL to 80 $\mathrm{mV}$ at EOL. This data is shown in Figure 36.

Figure 37 shows the EOL performance and cell spread vs. the BOL performance. The $130 \mathrm{mV}$ loss at OCV indicates hole formation and/or electrical shorting. The MEA compression issues introduced last quarter discuss our current thinking as to the potential cause of these failures. Also note that we observed $\mathrm{dV} / \mathrm{dA}=2 \mathrm{X} B O L$ which indicates high ohmic losses or significant mass transport limitations. Additional EOL diagnostics showed significant oxygen stoich sensitivity matching the Nernst potential supporting ohmic losses over mass transport limitations as the primary failure mode. Also significant hydrogen stoich sensitivity supports hole formation as an additional cause of degradation. 
HT Module 003

EOL Autopsy ( $7200 \mathrm{hrs})$

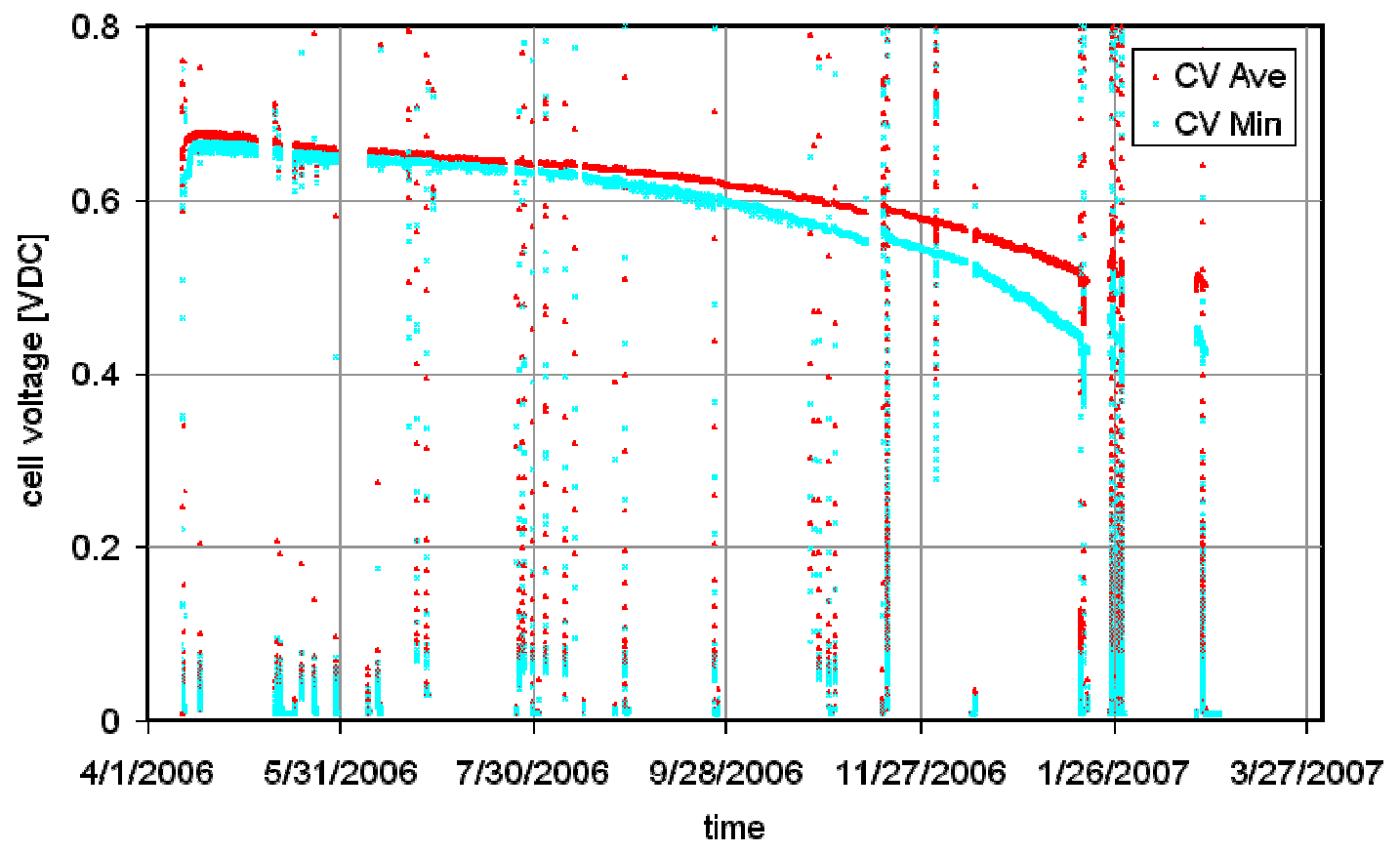

Figure 36: Module 003 Endurance Run Data

HT Module 003

EOL Autopsy (7200 hrs)

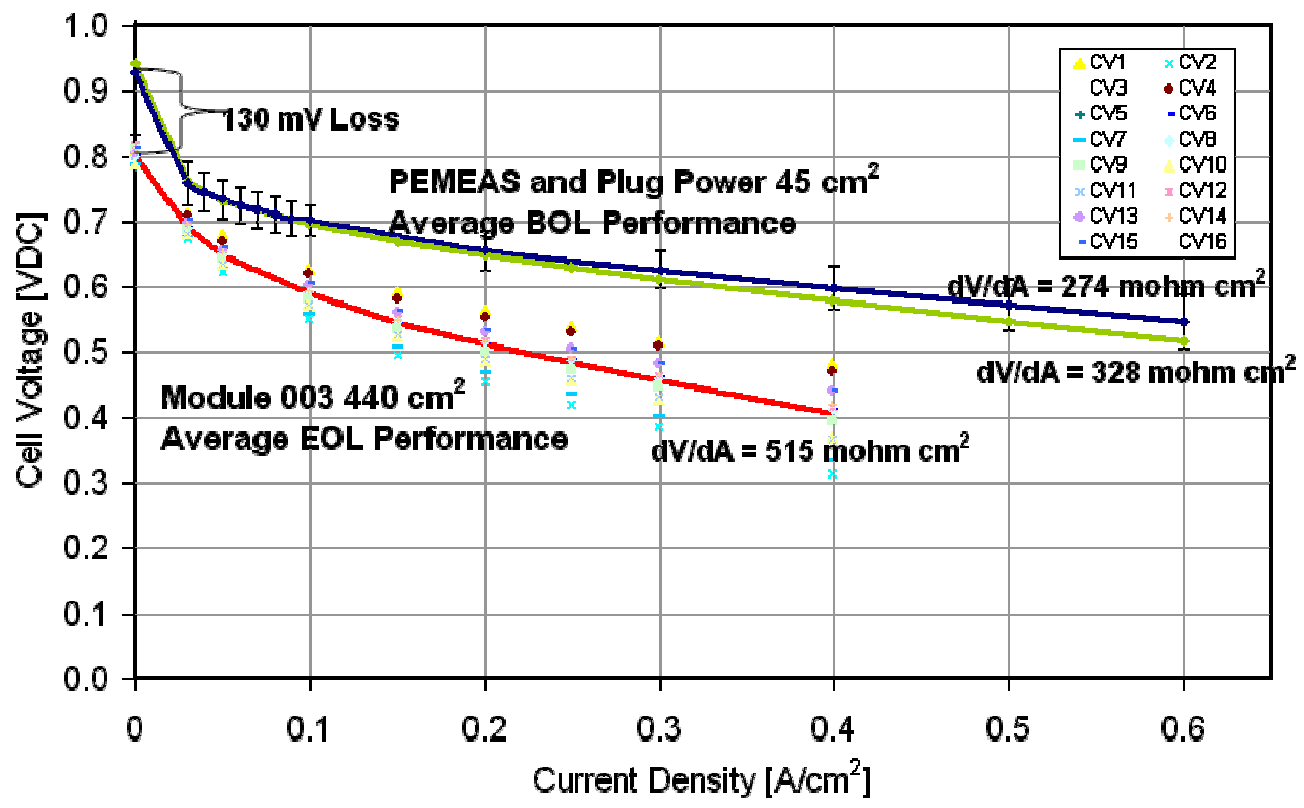

Figure 37: Module 003 BOL vs. EOL 


\section{FOCUS 2 RESULTS: MEA CHARACTERIZATION}

\section{Tasks 5 and 6: MEA Screening and Characterization}

Initial Work. Screening and characterization began with an MEA $\left(44 \mathrm{~cm}^{2}\right)$ made from Composition 2 membrane and standard commercially available electrodes tested on a fuel cell test station at RPI. The cell was operated at $160^{\circ} \mathrm{C}$ and ambient pressure. Polarization data was taken at constant $\mathrm{H}_{2}$ stoichs of 1.2 and air stoichs of 2.5. The polarization curve is shown in Figure 38. Cell performance was $0.648 \mathrm{~V}$ at $0.2 \mathrm{~A} / \mathrm{cm}^{2}$, within the range of expected values for these membranes and electrodes.

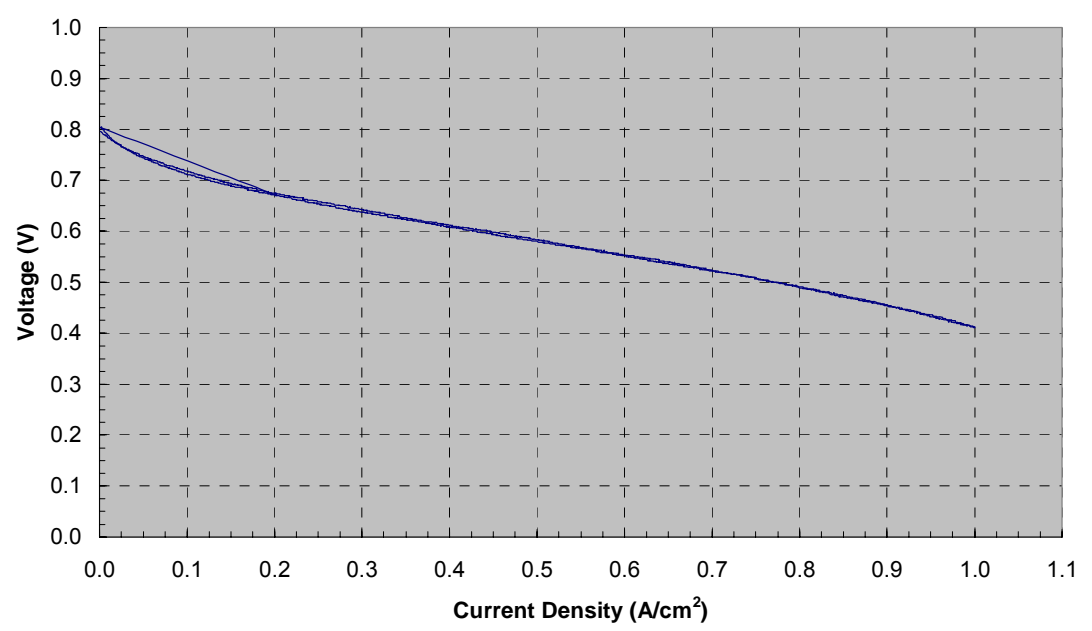

Figure 38: Polarization Curve of $44-\mathrm{cm}^{2}$ Cell

Polarization curves were obtained at 1,2, and 3 atmospheres (absolute). Cell performance at $1 \mathrm{~atm}$ greatly exceeded previously published data for early PBI-based membranes. The effect of pressure was found to be an increase in cell voltage of $\sim 75$ $\mathrm{mV}$ for each 10x increase in pressure; the theoretical increase for phosphoric acid fuel cells is $146 \mathrm{mV}$ (Fuel Cell Handbook, $4^{\text {th }}$ Edition, DOE/FETC-99/1076, November 1998). The corresponding increase for Nafion $®$-based membranes is $30 \mathrm{mV}$.

During this program a six-cell high temperature test station was delivered and installed at Plug Power's Latham facilities in order to perform many of the screening and characterization tests. See Figure 39. 


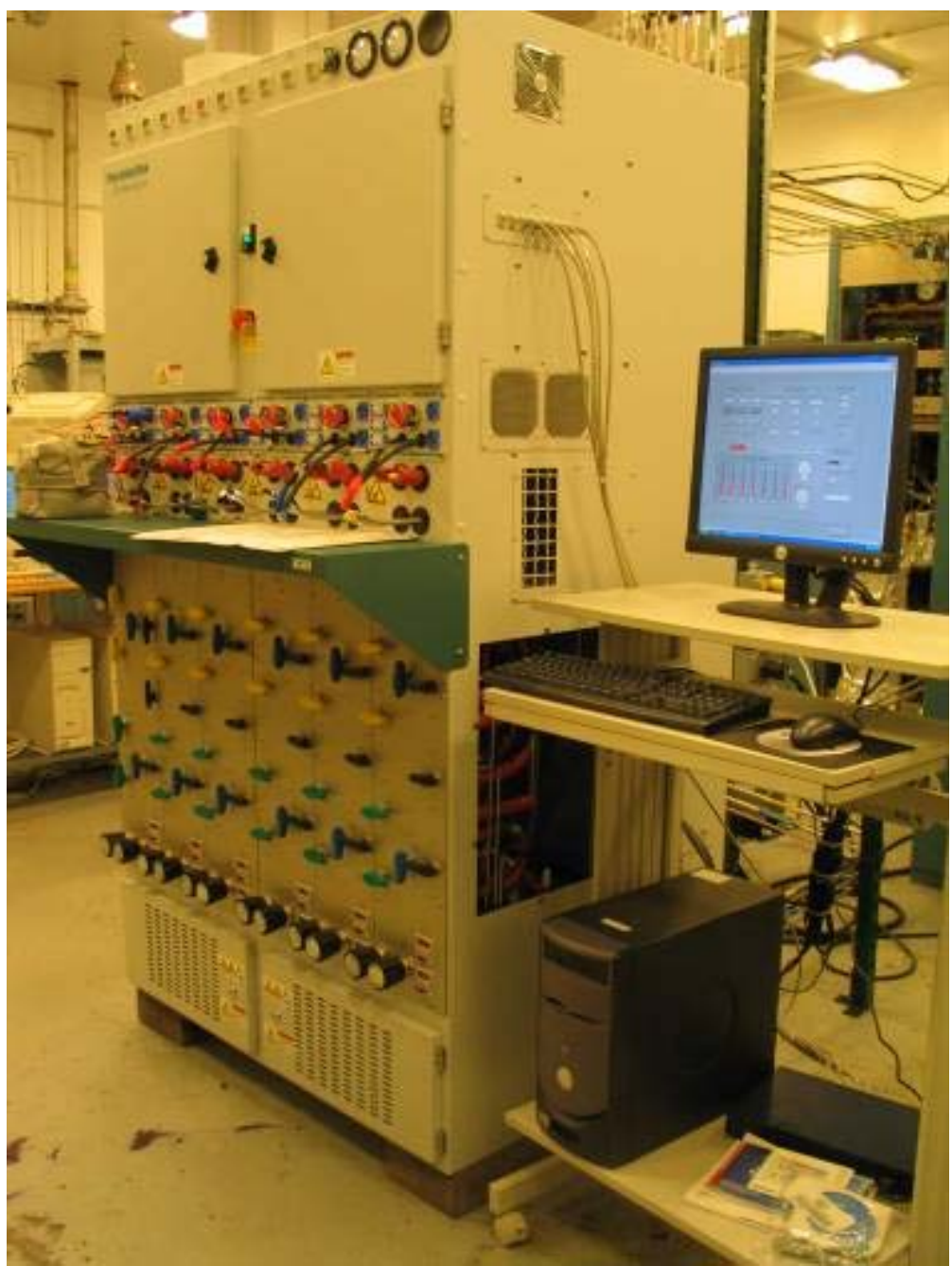

Figure 39: New Six-cell, High-temperature Test Station

RPI and Plug Power developed protocols for advanced MEA characterization that included durability evaluations by using cyclic testing. The cyclic testing protocols developed include load cycling, temperature cycling, and shut down-start up cycling. This required both hardware and software development at RPI and Plug Power. An initial automated cyclic load test using one of the filled systems (Composition 8) was performed and the results of this automated load test are shown in Figure 40. 


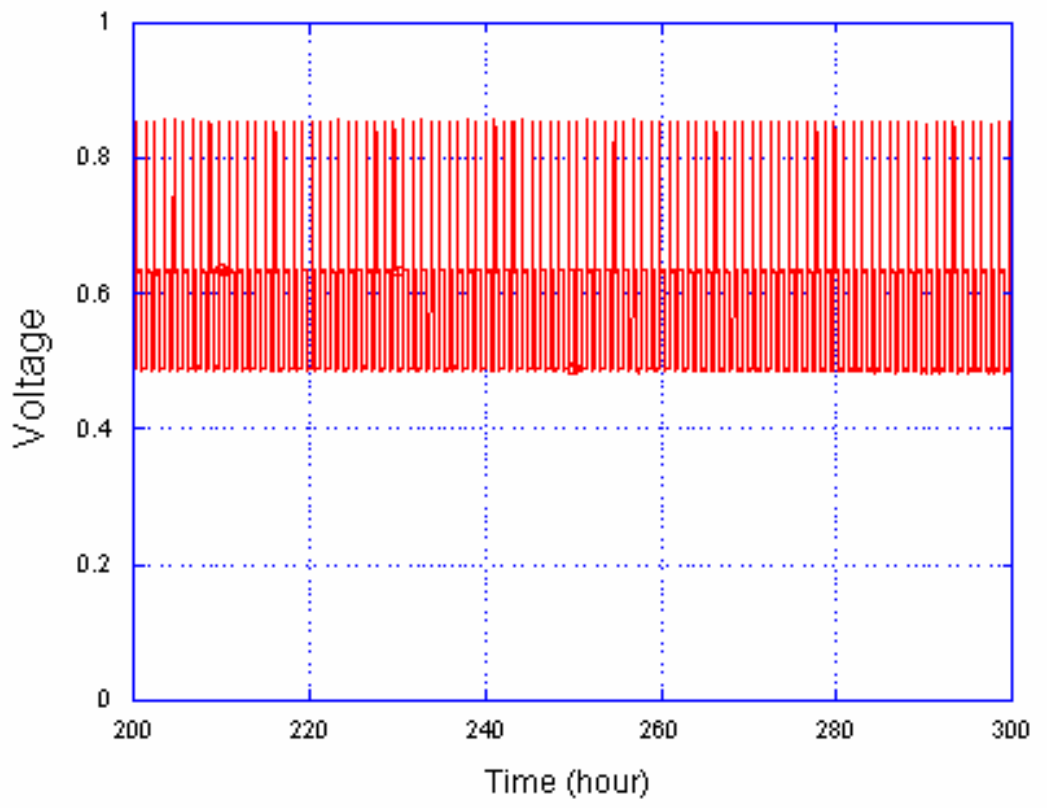

Figure 40: Automated Load Test

This graph shows a segment of such a test (100 cycles) where open current voltage (OCV) was measured for 2 minutes, then run at $0.2 \mathrm{~A} / \mathrm{cm}^{2}$ for thirty minutes, followed by $0.6 \mathrm{~A} / \mathrm{cm}^{2}$ for thirty minutes. This cycle was then repeated 500 times in an automated manner at $160^{\circ} \mathrm{C}$ in a constant stoich mode.

The complete test was conducted at $160^{\circ} \mathrm{C}$, hydrogen/air, 1.2/2.0 stoic, ambient pressure, and dry gases. In addition to the electrochemical measurements, the exhaust gases and water were collected over the entire test and analyzed for phosphoric acid loss. The exhaust analysis has been completed and is shown in Figure 41 combined with the overall cyclic test results. As seen in the graph, phosphoric acid loss is greater on the cathode than the anode. The total phosphoric acid loss of both electrodes over the time period studied was $28 \mathrm{ng} / \mathrm{cm}^{2} \mathrm{hr}$, which is lower than results reported for standard phosphoric acid fuel cells. In addition, the phosphoric acid loss rate under these cyclic conditions is not different from steady-state operation.

The results of thermal cyclic testing for the membrane used above are shown in Figure 42. In this test, the current density is set at $0.2 \mathrm{~A} / \mathrm{cm}^{2}$ with hydrogen/air, $1.2 / 2.0$ stoic, ambient pressure and the temperature of the cell is alternated between $120^{\circ}$ and $180^{\circ} \mathrm{C}$ for two hours at each temperature. This early test shows an initial degradation rate that is higher than the rate after about 300 hours. 


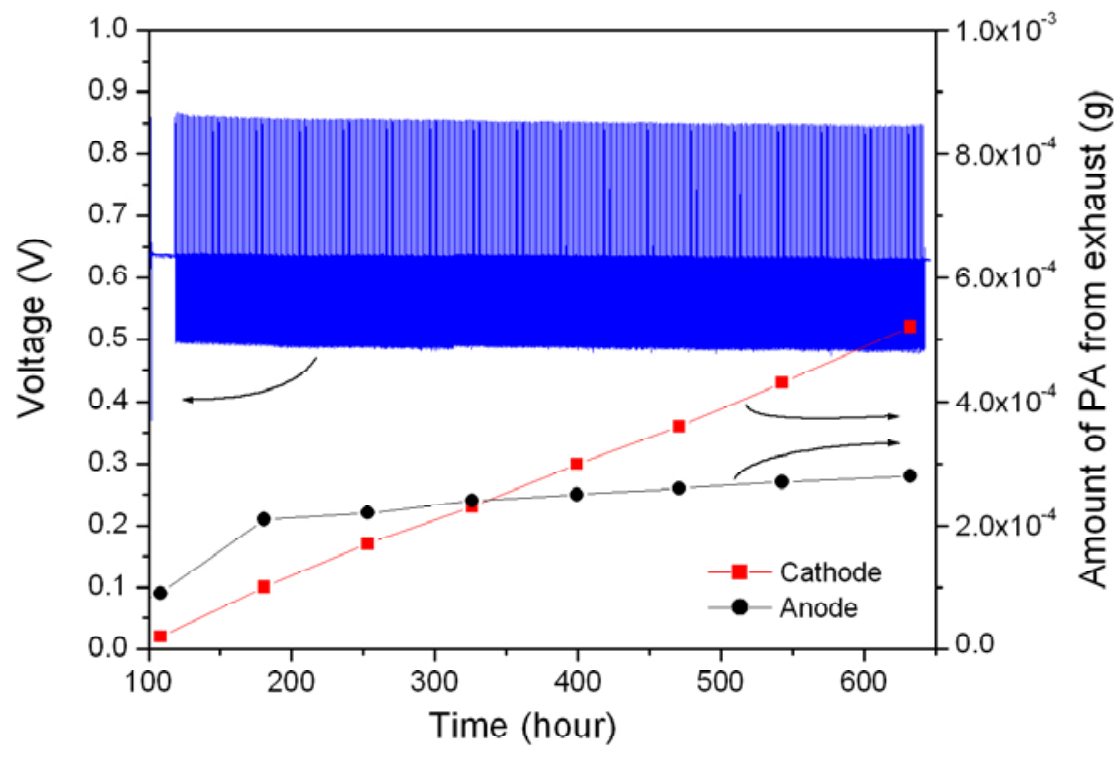

Figure 41: Thermal Cyclic Testing of 10\% Nanoparticle Filled PBI Membrane

Thermal cycling tests were also conducted on an unfilled PBI derivative. The cell was subjected to 100 cycles of $120-180^{\circ} \mathrm{C}$, followed by 100 cycles of $80-120^{\circ} \mathrm{C}$. The exhaust water was collected over the combined cycles and analyzed for phosphoric acid loss. Figure 42 plots the data, and Table 19 gives specific values. The voltage decay was less than that reported in the previous quarterly report for the high temperature cycle and showed surprisingly good stability at lower temperatures (80-120 C). 


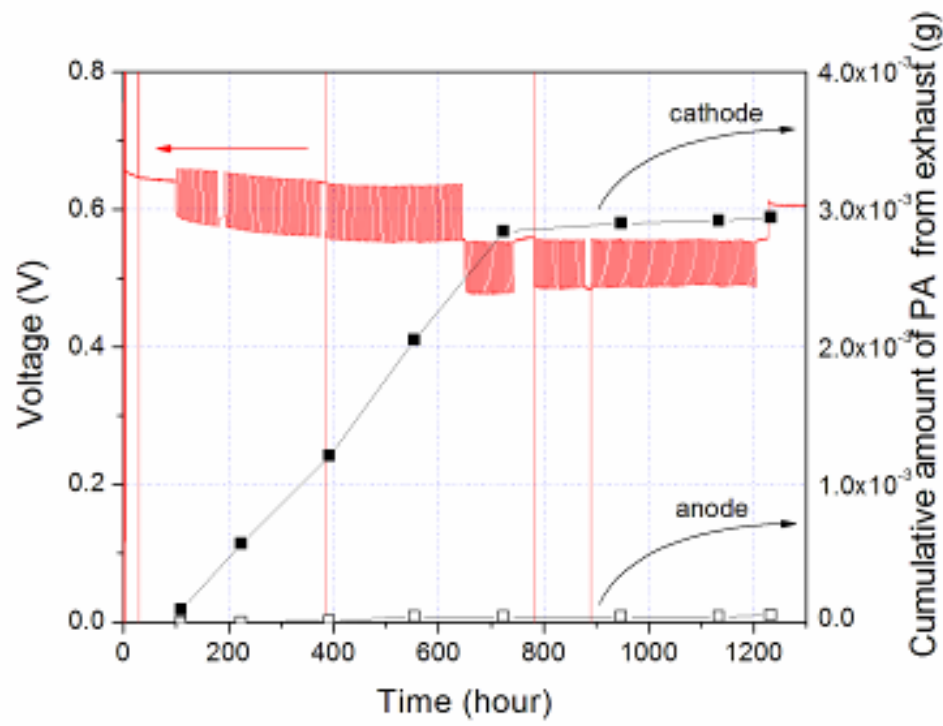

Thermal cycling tests

- $120^{\circ} \mathrm{C} \leftrightarrow 180^{\circ} \mathrm{C}$ and $80^{\circ} \mathrm{C} \leftrightarrow$ $120^{\circ} \mathrm{C}$

2 hours at each temperature

- 100 cycles/set

- Constant current density, 0.2 $\mathrm{A} / \mathrm{cm}^{2}$

- Constant stoic

$\mathrm{H}_{2}, 1.2$ stoic/air, 2.0 stoic

Figure 42: Thermal Cycling Tests on an Unfilled PBI Derivative

\begin{tabular}{|c|c|c|}
\hline & $120-180^{\circ} \mathrm{C}$ cycles & $80-120^{\circ} \mathrm{C}$ cycles \\
\hline Voltage drop $\left(120^{\circ} \mathrm{C}\right)$ & $66 \mu \mathrm{V} / \mathrm{hr}(360 \mu \mathrm{V} /$ cycle $)$ & $1.8 \mu \mathrm{V} / \mathrm{hr}(10 \mu \mathrm{V} /$ cycle $)$ \\
\hline Acid loss rate (cathode) & $32 \mathrm{ng} / \mathrm{cm}^{2} \mathrm{hr}$ & $2.3 \mathrm{ng} / \mathrm{cm}^{2} \mathrm{hr}$ \\
\hline
\end{tabular}

Table 19: Specific Values for Thermal Cycling Test on an Unfilled PBI Derivative

Endurance Tests. At Plug Power a series of endurance tests were run on $50 \mathrm{~cm}^{2}$ cells fabricated with the baseline Type 2 membrane in order to evaluate long term voltage stability under a range of operating conditions. All cells were run at $180^{\circ} \mathrm{C}$, utilizing reformate and air as reactants. Three cells were run in constant current mode, two at high current density, and one at low. Two additional cells were load cycled over a load range which spans the extremes of system operating conditions. The load cycle and high current cells were run for 3000 hours, while the low current density cell was run for 1000 hours. The average degradation rate for these cells was approximately $35 \mu \mathrm{V} / \mathrm{hr}$, with no discernable trend with respect to operating conditions.

A series of diagnostics were run on these cells at the beginning and end of life in order to separate the degradation mechanisms. The results as shown in Table 1 indicate that the main contributor to the degradation is loss of cathode catalyst active area not increases in mass transport loss or membrane resistance.

\begin{tabular}{|c|c|c|c|c|c|c|c|}
\hline Test & Cell & Time (hr) & Initial Cell & Final & Change & Initial & Final \\
\hline
\end{tabular}




\begin{tabular}{|l|c|c|c|c|c|c|c|}
\hline & & voltage & $\begin{array}{c}\text { Cell } \\
\text { voltage }\end{array}$ & $\begin{array}{c}\text { in } \\
\text { voltage }\end{array}$ & $\begin{array}{c}\text { Catalyst } \\
\text { Activity }\end{array}$ & $\begin{array}{c}\text { Catalyst } \\
\text { Activity }\end{array}$ \\
\hline $\begin{array}{l}\text { Steady- } \\
\text { State Full } \\
\text { Power }\end{array}$ & 3059 & 3000 & 0.66 & 0.565 & 0.095 & 19 & 8 \\
\hline $\begin{array}{l}\text { Steady- } \\
\text { State Full } \\
\text { Power }\end{array}$ & 3061 & 3000 & 0.657 & 0.58 & 0.077 & & 9 \\
\hline Load Cycle & 3067 & 3000 & 0.673 & 0.58 & 0.093 & 32 & 9 \\
\hline Load Cycle & 3064 & 3000 & 0.664 & 0.59 & 0.074 & 29 & 8 \\
\hline Low Power & 3057 & 1000 & 0.652 & 0.617 & 0.035 & 27 & 11 \\
\hline
\end{tabular}

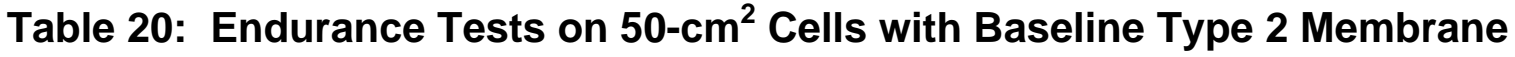

Load Cycling Impact on Fuel Cell Performance and Degradation. The impact of open circuit voltage (OCV) on the performance and degradation of $\mathrm{PBI}-\mathrm{H}_{3} \mathrm{PO}_{4}$ fuel cells operated at both 160 and $180^{\circ} \mathrm{C}$ was investigated. A total of six $45-\mathrm{cm}^{2}$ single cells were studied with two cells cycling load between 0.2 and $0.4 \mathrm{~A} / \mathrm{cm}^{2}$ at 15 -minute intervals (cells 3244,3245 ), two cells at constant load of $0.2 \mathrm{~A} / \mathrm{cm}^{2}$ (cells 3240,3242 ), and two cells at constant load of $0.4 \mathrm{~A} / \mathrm{cm}^{2}$ (cells 3241, 3243). In order to avoid reactant starvation during the load change steps, constant flow rates of $\mathrm{H}_{2}(0.15 \mathrm{SLM})$ and air (0.60 SLM) were used for all the six cells.

The OCV showed an initial increase, followed by an exponential and monotonous decline. Along with the decline of OCV, the performance of the fuel cell also declined. Operating the fuel cell with a load of $0.2 \mathrm{~A} / \mathrm{cm}^{-2}$ could temporarily boost the OCV and the fuel cell performance, but it could not recover the lost performance permanently. Electrochemical impedance spectroscopy indicated significant loss of catalyst activity and increase in mass transport resistance due to the relatively high potential at OCV. Xray diffraction measurement showed that the cathode Pt grain size increased as much as $430 \%$ after a total of 244.5 hours of exposure to OCV.

A fuel cell is often required to operate in a load-following mode where the load changes frequently. The fuel cell will follow the load change by varying its current and voltage outputs. A critical question that needs to be answered is whether a fuel cell will decay faster in a load-following mode than in a steady-state run mode.

Key Results. Fig. 43 shows the OCV change of a fuel cell during about a total of 350 hours of testing (with 244.5 hours at OCV). The OCV increased initially before it started an exponential and monotonic decline. For regions $A$ and $B$ (circled by dotted lines), the fuel cell was set at $0.2 \mathrm{~A} \mathrm{~cm}^{-2}$ for 7.5 and 96 hours respectively, and no apparent OCV loss was observed. When the cell was returned to open circuit after 96 hours at $0.2 \mathrm{~A} /$ $\mathrm{cm}^{-2}$, the OCV quickly declined from 0.875 to $0.826 \mathrm{~V}$ in 22 hours, returning to the original OCV decline trend line. 


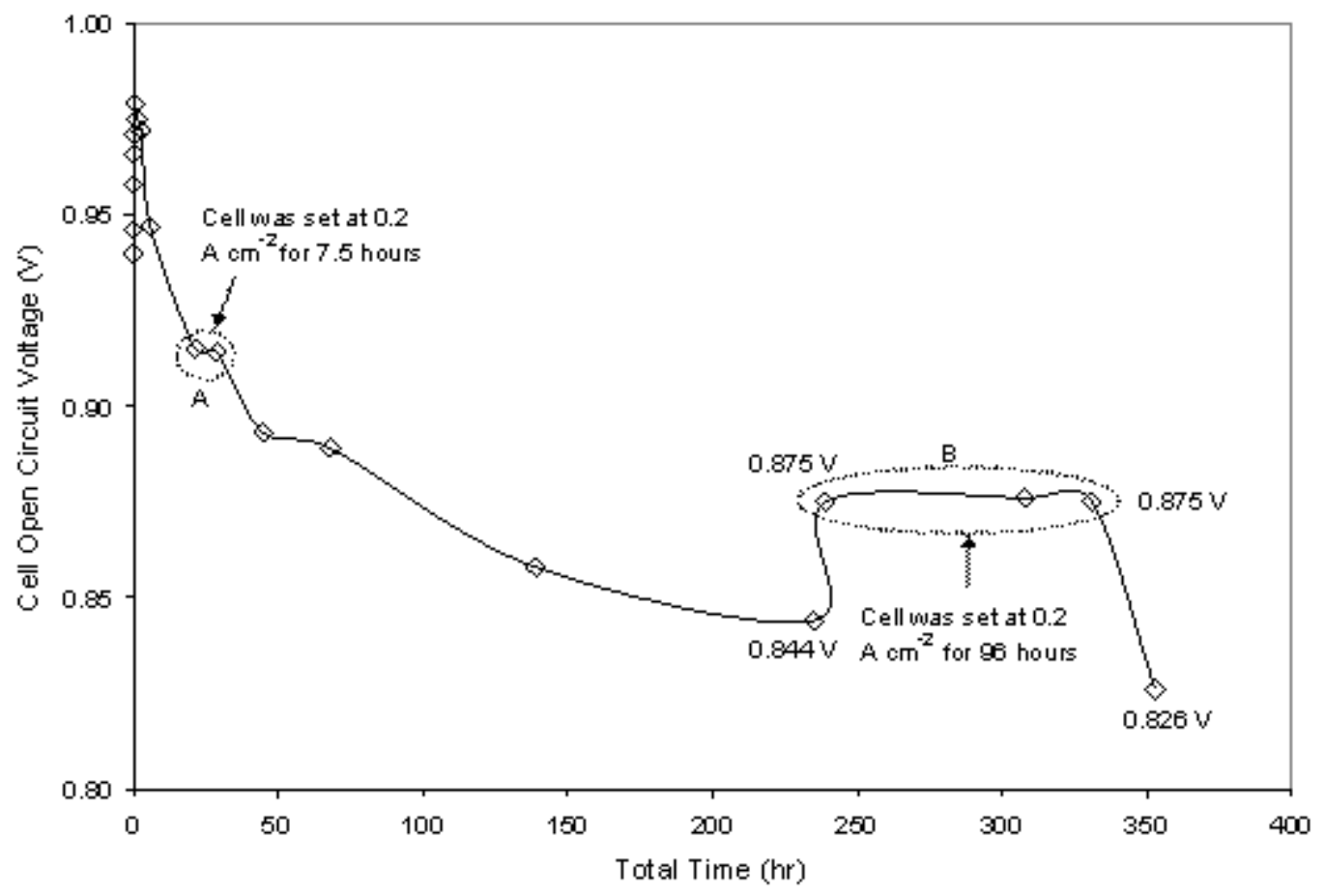

Figure 43: Thermal Cycling Tests on an Unfilled PBI Derivative

The polarization curves at 1.35 stoichiometric air flow rate after different hours of OCV are shown in Fig. 44. The hours shown in the legend are accumulated number of hours at OCV. The performance loss occurred throughout the entire current density region, and most of the loss occurred in the first 33.5 hours. Afterwards, the performance decline rate slowed down significantly. 


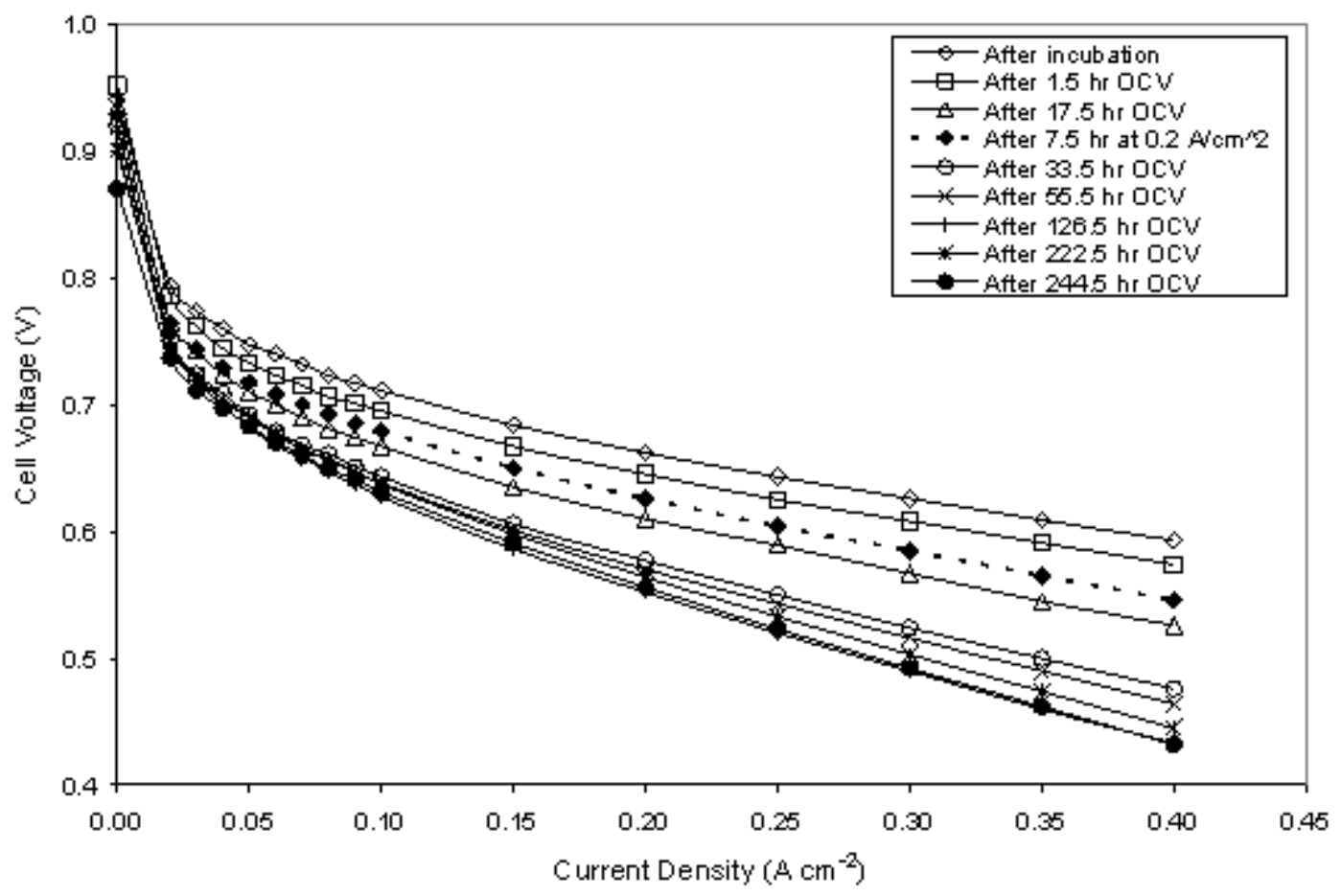

Figure 44: Thermal Cycling Tests on an Unfilled PBI Derivative

During the OCV testing process, electrochemical impedance spectra (EIS) were taken periodically in order to monitor the changes of the cathode kinetic activity and the mass transport resistance. Fig. 3 shows the EIS obtained at a fuel cell current density of $0.2 \mathrm{~A}$ $\mathrm{cm}^{-2}$ with 1.35 times stoichiometric air flow rate after 1.5 and 244.5 hours of OCV, respectively. Both spectra show two distinct arcs in the high and low frequency regions, representing the electrode activation resistance and the mass transport resistance, respectively. Both the activation resistance and the mass transport resistance increased significantly after 244.5 hours of OCV. 


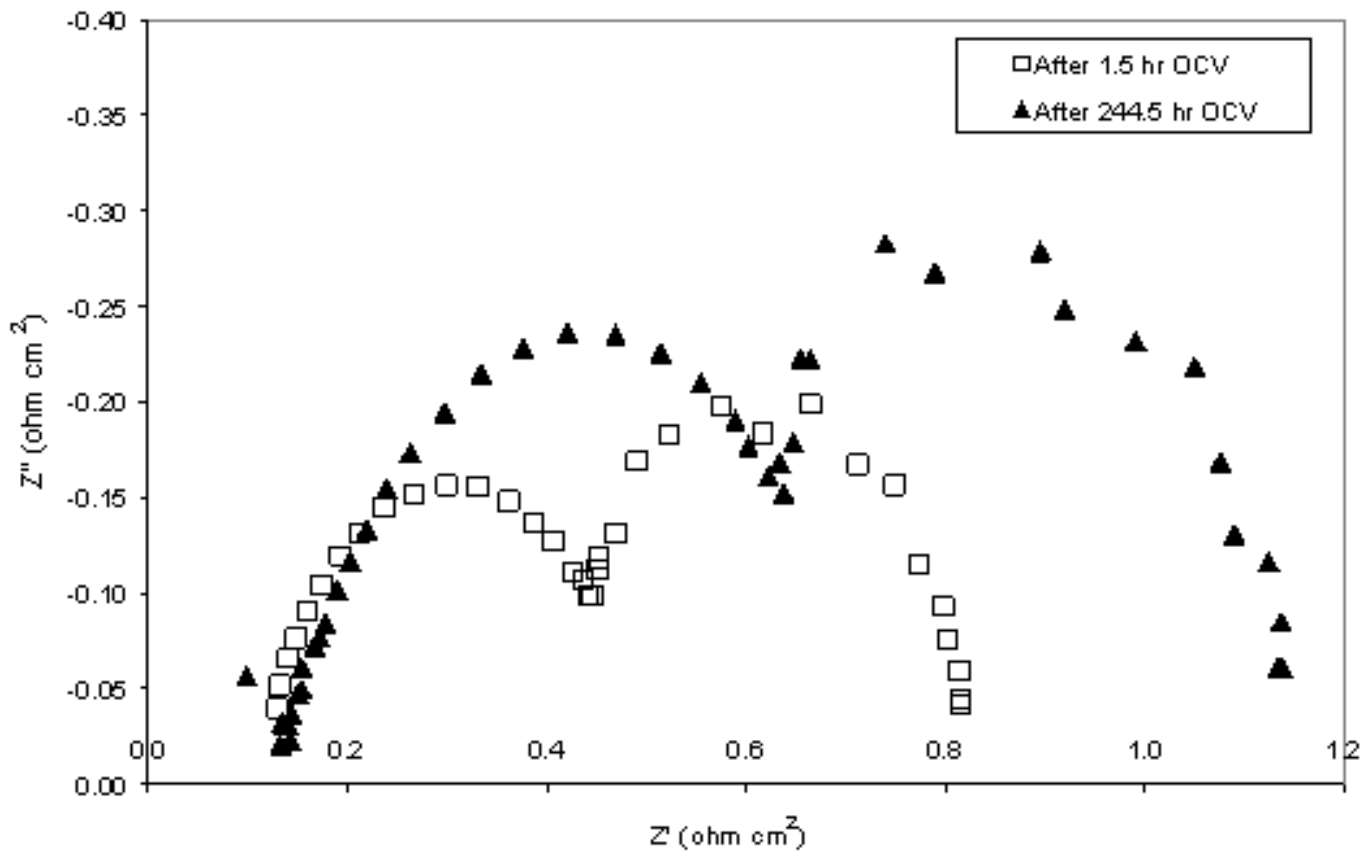

Figure 45: Thermal Cycling Tests on an Unfilled PBI Derivative

X-ray diffraction (XRD) was used to estimate the catalyst particle grain size changes at both the cathode and the anode. Three Pt peaks were observed at $39.8^{\circ}(111-$ crystalline facet), $46.2^{\circ}(200)$, and $67.6^{\circ}(220)$. These peaks were all much sharper for the tested cathode than for the fresh cathode, indicating that the Pt grain size increased in the tested cathode. Using the Debye-Scherrer equation: Grain Size $=(0.9 \times \lambda) /$ $(F W H M x \cos \theta)$, the Pt grain sizes were estimated. Table 21 shows the results that are normalized by taking the smallest grain size as 1.0. The Pt grain size increased as much as $430 \%$ after 244.5 hours of testing at OCV.

\begin{tabular}{|l|c|c|c|c|}
\hline Sample & \multicolumn{2}{|l|}{$\begin{array}{l}\text { Pt peak position (degrees } \\
2 \theta)\end{array}$} & FWHM & $\begin{array}{l}\text { Normalized grain size } \\
(\mathrm{nm})\end{array}$ \\
\hline \multirow{3}{*}{$\begin{array}{l}\text { Fresh } \\
\text { cathode }\end{array}$} & $39.9^{\circ}$ & $(111)$ & 2.38 & 1.6 \\
\cline { 2 - 5 } & $46.1^{\circ}$ & $(200)$ & 4.22 & 1.0 \\
\cline { 2 - 5 } & $67.7^{\circ}$ & $(220)$ & 2.42 & 3.2 \\
\hline \multirow{2}{*}{$\begin{array}{l}\text { Tested } \\
\text { cathode }\end{array}$} & $39.8^{\circ}$ & $(111)$ & 0.68 & 5.6 \\
\cline { 2 - 5 } & $46.2^{\circ}$ & $(200)$ & 0.80 & 5.3 \\
\cline { 2 - 5 } & $67.7^{\circ}$ & $(220)$ & 1.00 & 7.7 \\
\hline
\end{tabular}


Table 21: Normalized Cathode Pt Grain Size Estimated by XRD Measurement

However, the estimated Pt grain sizes were almost the same for the fresh and tested anodes, as shown in Table 2.

\begin{tabular}{|l|c|c|c|c|}
\hline Sample & \multicolumn{2}{|l|}{$\begin{array}{l}\text { Pt peak position (degrees } \\
2 \theta)\end{array}$} & FWHM & $\begin{array}{l}\text { Normalized grain size } \\
(\mathrm{nm})\end{array}$ \\
\hline \multirow{3}{*}{$\begin{array}{l}\text { Fresh } \\
\text { anode }\end{array}$} & $39.8^{\circ}$ & $(111)$ & 1.80 & 1.4 \\
\cline { 2 - 5 } & $46.1^{\circ}$ & $(200)$ & 2.88 & 1.0 \\
\cline { 2 - 5 } & $67.5^{\circ}$ & $(220)$ & 2.20 & 2.4 \\
\hline \multirow{3}{*}{$\begin{array}{l}\text { Tested } \\
\text { anode }\end{array}$} & $39.8^{\circ}$ & $(111)$ & 1.56 & 1.7 \\
\cline { 2 - 5 } & $46.2^{\circ}$ & $(200)$ & 2.93 & 1.0 \\
\cline { 2 - 5 } & $67.7^{\circ}$ & $(220)$ & 2.31 & 2.3 \\
\hline
\end{tabular}

Table 22: Normalized Anode Pt Grain Size Estimated by XRD Measurement

Table 23 lists the decay rate of the six cells tested at $160 \mathrm{C}$ before the lab event at around 452-hr time mark. For cell 3207 the $36 \mathrm{mV}$ loss due to the station trip was excluded from the decay rate calculation. At a current density of $0.2 \mathrm{~A} / \mathrm{cm}^{2}$, the two load cycling cells showed decay rates between 49 and $63 \mu \mathrm{V} / \mathrm{h}$, while the steady state cells showed decay rates from 20 to $89 \mu \mathrm{V} / \mathrm{h}$; at a current density of $0.4 \mathrm{~A} / \mathrm{cm}^{2}$, the two load cycling cells showed decay rates between 89 and $112 \mu \mathrm{V} / \mathrm{h}$, while the steady state cells showed decay rates from 51 to $125 \mu \mathrm{V} / \mathrm{h}$. Based on these results, it seemed that the decay rates with load cycling were in the same range as at steady states.

Table 24 shows the decay rate of all the six cells tested at $160 \mathrm{C}$ for the entire testing period of slightly more than 800 hours. For cell 3203, the decay rates were calculated between 460 and 850 hours. Since this cell was severely damaged by the lab event at 452 hours, its decay rate became much faster, and that portion of the data should be excluded from comparison with other data. At a current density of $0.2 \mathrm{~A} / \mathrm{cm}^{2}$, the (other) load cycling cell showed a decay rate of $40 \mu \mathrm{V} / \mathrm{h}$, while the steady state cells showed decay rates from 32 to $65 \mu \mathrm{V} / \mathrm{h}$ excluding the losses due to station trips; at a current density of $0.4 \mathrm{~A} / \mathrm{cm}^{2}$, the (other) load cycling cell showed a decay rate of $67 \mu \mathrm{V} / \mathrm{h}$, while the steady state cells showed decay rates from 35 to $65 \mu \mathrm{V} / \mathrm{h}$. Again, it seemed that the decay rates with load cycling were in the same range as at steady states.

\begin{tabular}{|c|c|c|c|c|c|c|c|}
\hline $\begin{array}{c}\text { Cell } \\
\text { number }\end{array}$ & 3203 & 3204 & 3205 & 3206 & 3207 & 3208 & $\begin{array}{c}\text { Average } \\
\text { decay } \\
\text { rate }\end{array}$ \\
\hline
\end{tabular}




\begin{tabular}{|c|c|c|c|c|c|c|c|}
\hline $\begin{array}{c}\text { Running } \\
\text { mode }\end{array}$ & $\begin{array}{c}0.2-0.4 \\
\mathrm{~A} / \mathrm{cm}^{2} \\
\text { Cycling }\end{array}$ & $\begin{array}{c}0.2-0.4 \\
\mathrm{~A} / \mathrm{cm}^{2} \\
\text { Cycling }\end{array}$ & $\begin{array}{c}0.4 \\
\mathrm{~A} / \mathrm{cm}^{2} \\
\text { Steady }\end{array}$ & $\begin{array}{c}0.2 \mathrm{~A} / \mathrm{cm}^{2} \\
\text { Steady }\end{array}$ & $\begin{array}{c}0.4 \\
\mathrm{~A} / \mathrm{cm}^{2} \\
\text { Steady }\end{array}$ & $\begin{array}{c}0.2 \mathrm{~A} / \mathrm{cm}^{2} \\
\text { Steady }\end{array}$ & $(\mu \mathrm{V} / \mathrm{h})$ \\
\hline $\begin{array}{c}\text { Decay } \\
\text { rate } \\
(\mu \mathrm{V} / \mathrm{h}) \text { at } \\
0.2 \mathrm{~A} / \mathrm{cm}^{2}\end{array}$ & 63 & 49 & 20 & 89 & 55 \\
\hline $\begin{array}{c}\text { Decay } \\
\text { rate } \\
(\mu \mathrm{V} / \mathrm{h}) \text { at } \\
0.4 \mathrm{~A} / \mathrm{cm}^{2}\end{array}$ & 112 & 89 & 51 & & $125^{*}$ & & 94 \\
\hline
\end{tabular}

${ }^{*}$ Excluding 36-mV loss due to trip

Table 23: Decay Rate in About 450 hours of Testing $-160^{\circ} \mathrm{C}$

\begin{tabular}{|c|c|c|c|c|c|c|c|}
\hline $\begin{array}{c}\text { Cell } \\
\text { number }\end{array}$ & 3203 & 3204 & 3205 & 3206 & 3207 & 3208 & $\begin{array}{c}\text { Average } \\
\text { decay } \\
\text { rate } \\
(\mu \mathrm{V} / \mathrm{h})\end{array}$ \\
\hline $\begin{array}{c}\text { Running } \\
\text { mode }\end{array}$ & $\begin{array}{c}0.2-0.4 \\
\mathrm{~A} / \mathrm{cm}^{2} \\
\text { Cycling }\end{array}$ & $\begin{array}{c}0.2-0.4 \\
\mathrm{~A} / \mathrm{cm}^{2} \\
\text { Cycling }\end{array}$ & $\begin{array}{c}0.4 \\
\mathrm{~A} / \mathrm{cm}^{2} \\
\text { Steady }\end{array}$ & $\begin{array}{c}0.2 \mathrm{~A} / \mathrm{cm}^{2} \\
\text { Steady }\end{array}$ & $\begin{array}{c}0.4 \\
\mathrm{~A} / \mathrm{cm}^{2} \\
\text { Steady }\end{array}$ & $\begin{array}{c}0.2 \mathrm{~A} / \mathrm{cm}^{2} \\
\text { Steady }\end{array}$ & \\
\hline $\begin{array}{c}\text { Decay } \\
\text { rate } \\
(\mu \mathrm{V} / \mathrm{h}) \text { at } \\
0.2 \mathrm{~A} / \mathrm{cm}^{2}\end{array}$ & $194^{*}$ & 40 & $32^{* *}$ & & $65^{* * *}$ & 46 \\
\hline $\begin{array}{c}\text { Decay } \\
\text { rate } \\
(\mu \mathrm{V} / \mathrm{h}) \text { at } \\
0.4 \mathrm{~A} / \mathrm{cm}^{2}\end{array}$ & $362^{*}$ & 67 & 35 & $8^{* * *}$ & & 63 \\
\hline
\end{tabular}

* Excluded from calculating the average decay rate shown in the last column

** Excluding 8-mV loss due to trip

${ }^{* * *}$ Excluding $36-\mathrm{mV}$ loss due to trip

Table 24: Decay Rate in About 850 hours of Testing $-160^{\circ} \mathrm{C}$

Fig. 46 shows the BOL polarization curves of all the 6 cells. Except for cell 3240 , all the other five cells showed almost identical performance in the entire current density region. $1 \mathrm{kHz}$ impedance performed at $0.2 \mathrm{~A} / \mathrm{cm}^{2}$ showed that cell 3240 had a total resistance 
about $50 \%$ higher than other cells. It is believed that this higher resistance was at least partly responsible for the lower performance of this cell.

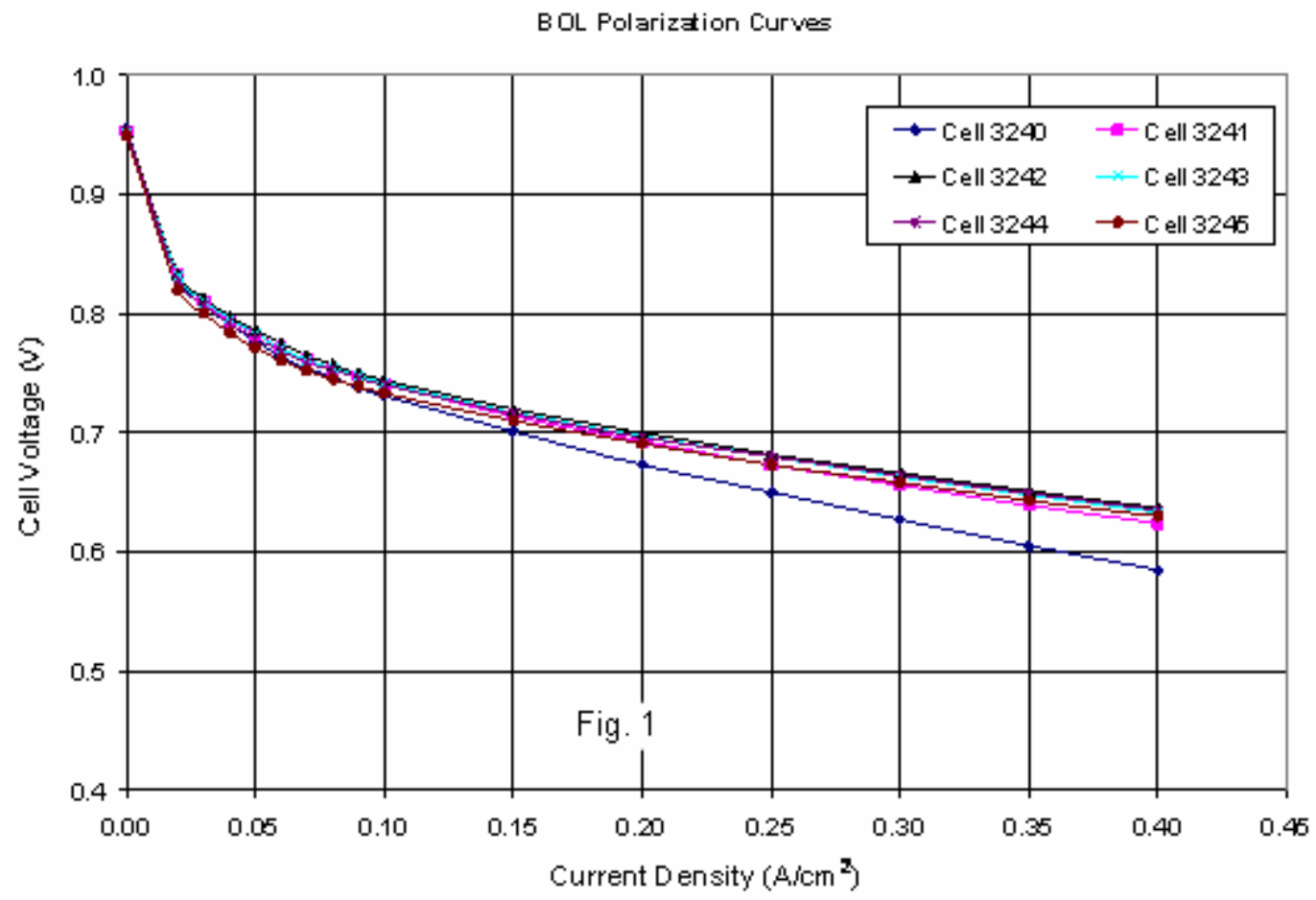

Figure 46: Thermal Cycling Tests on an Unfilled PBI Derivative

The performance histories of all the six cells are shown in Figures 47 to 52 . All the cells showed smooth and gradual voltage decay with run time. In order to estimate the voltage decay rate, an initial stable voltage was selected after the desired load (s) had been applied and the endurance test had been started. The decay rate was then calculated by dividing the voltage difference between the initial stable voltage and the end voltage with the number of testing hours. The initial stable voltage and the end voltage, along with the calculated voltage decay rate, are shown in all the figures. 
HT Cal 3240 - Performance History

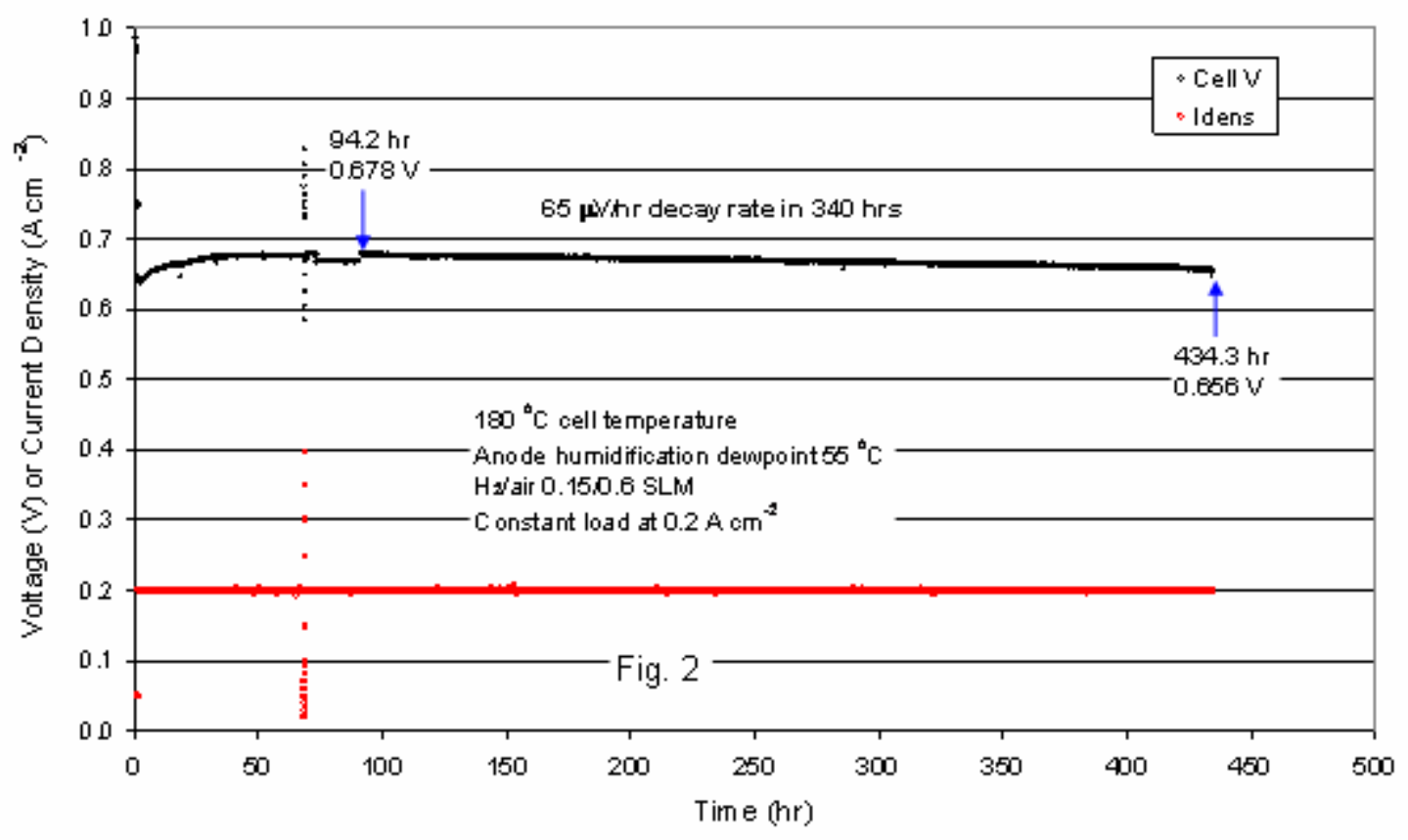

Figure 47: Cell 3240 Endurance Data

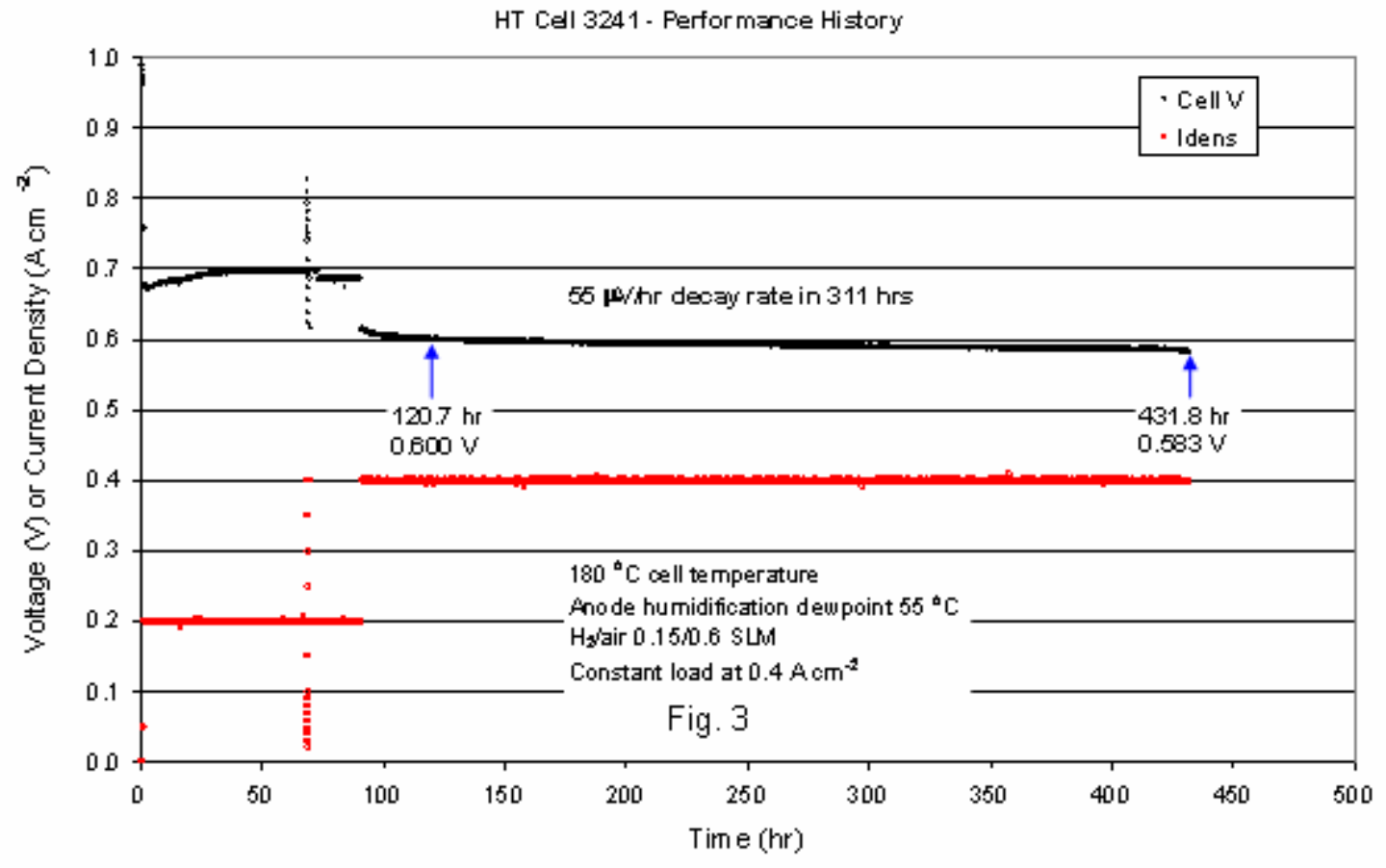

Figure 48: Cell 3241 Endurance Data 


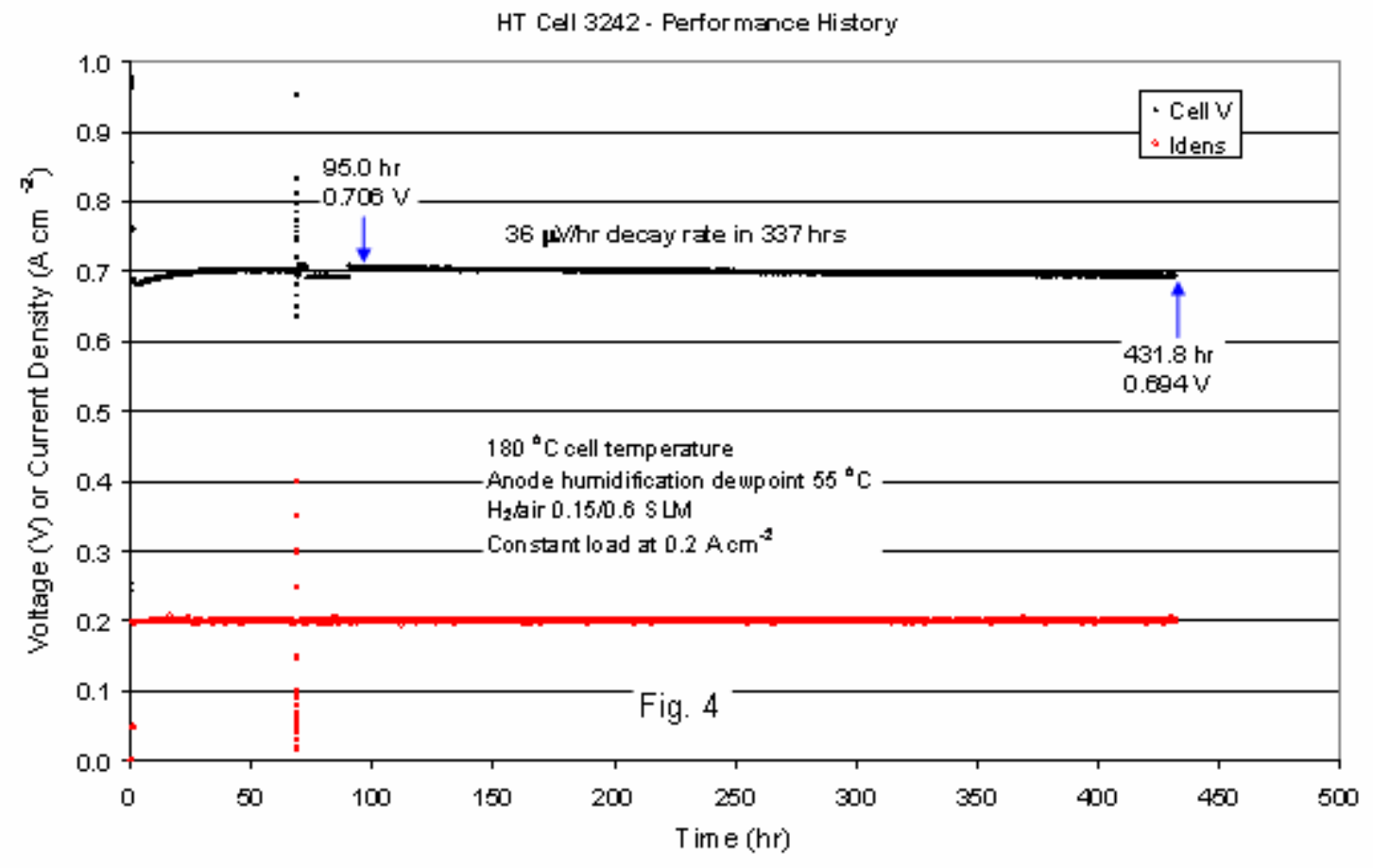

Figure 49: Cell 3242 Endurance Data 
HT Cell 3243 - Performance History

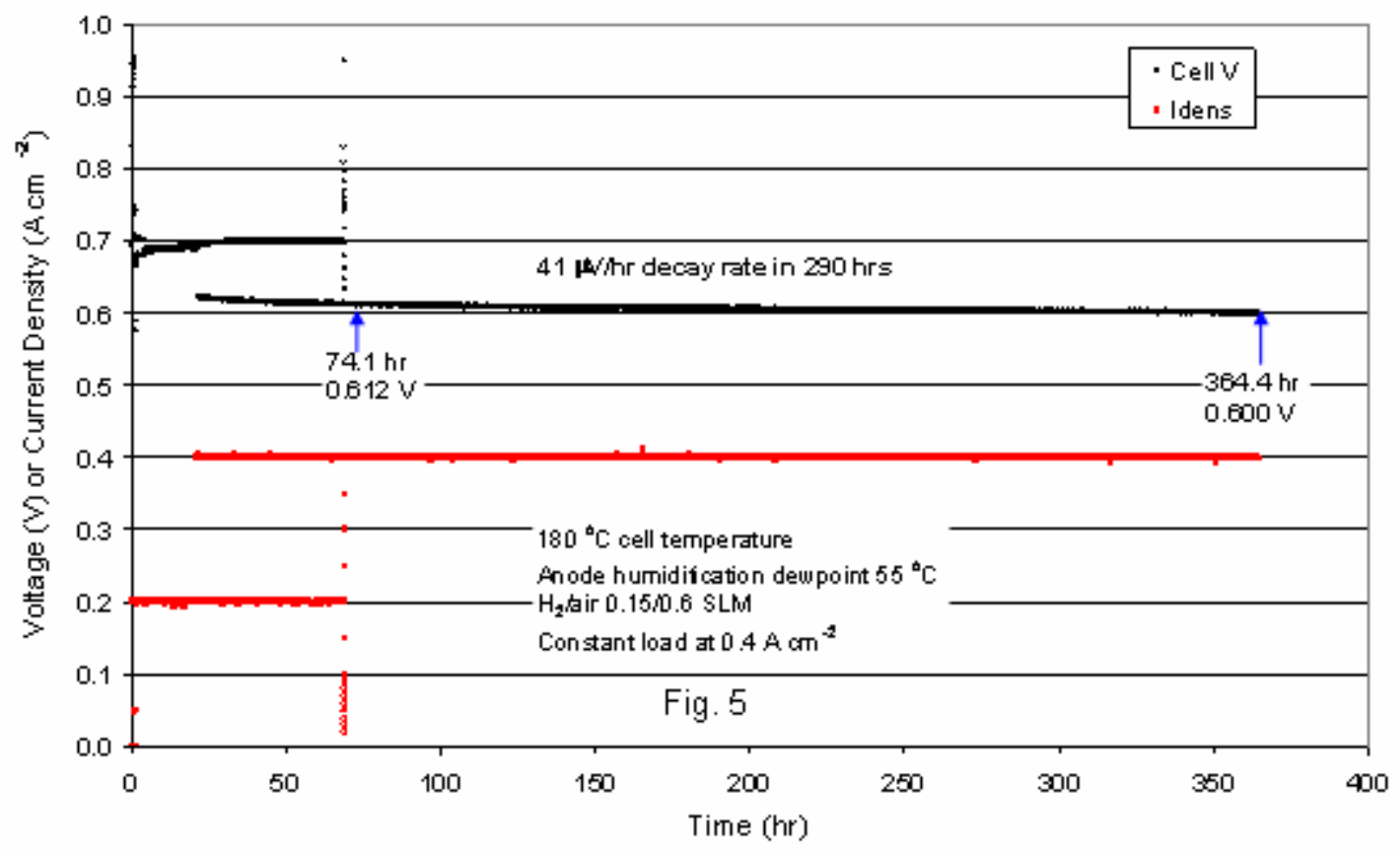

Figure 50: Cell 3243 Endurance Data

HT Cell 3244 - Perfor mance History

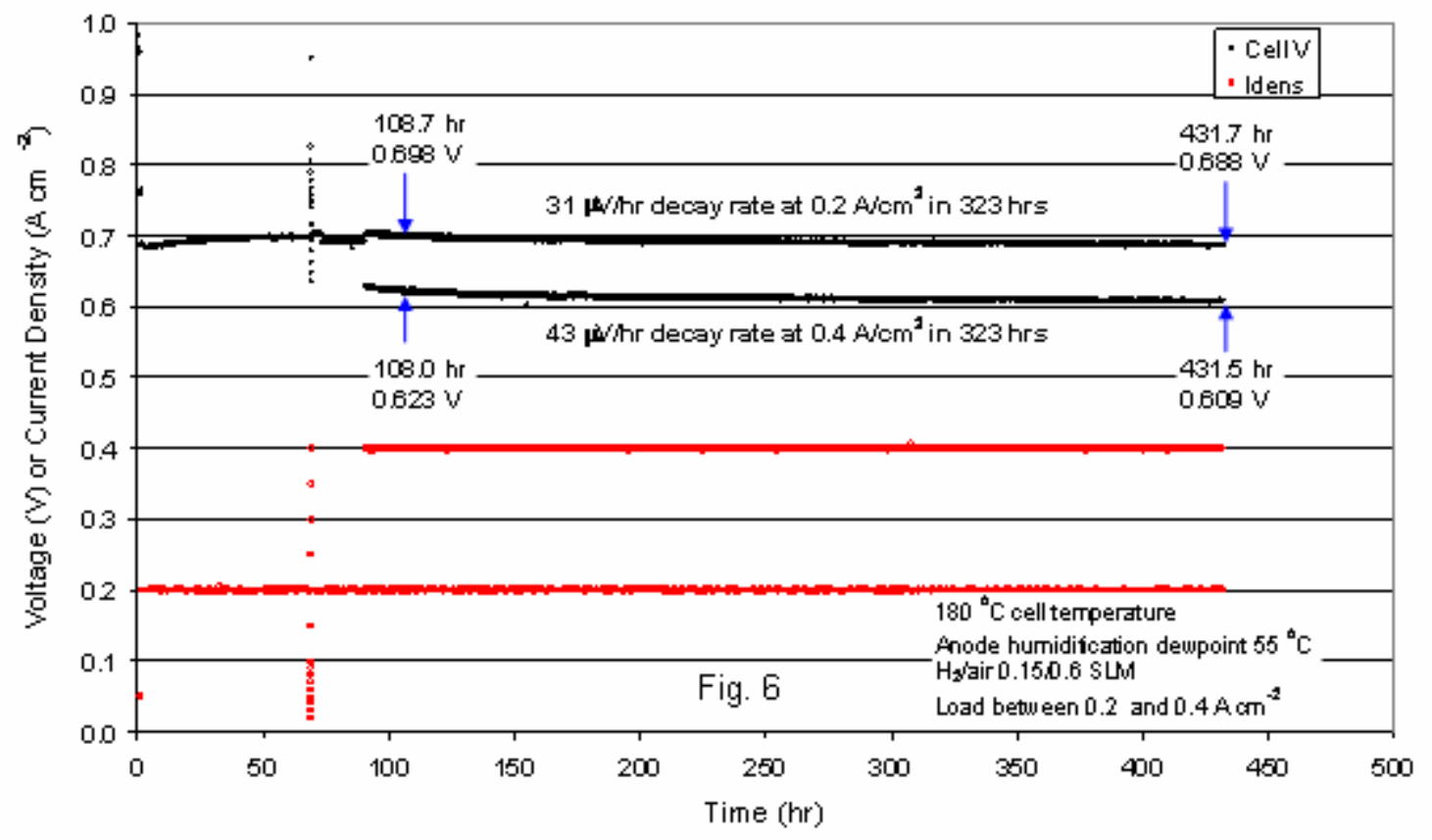

Figure 51: Cell 3244 Endurance Data 
HT Cell 3245 - Performance History

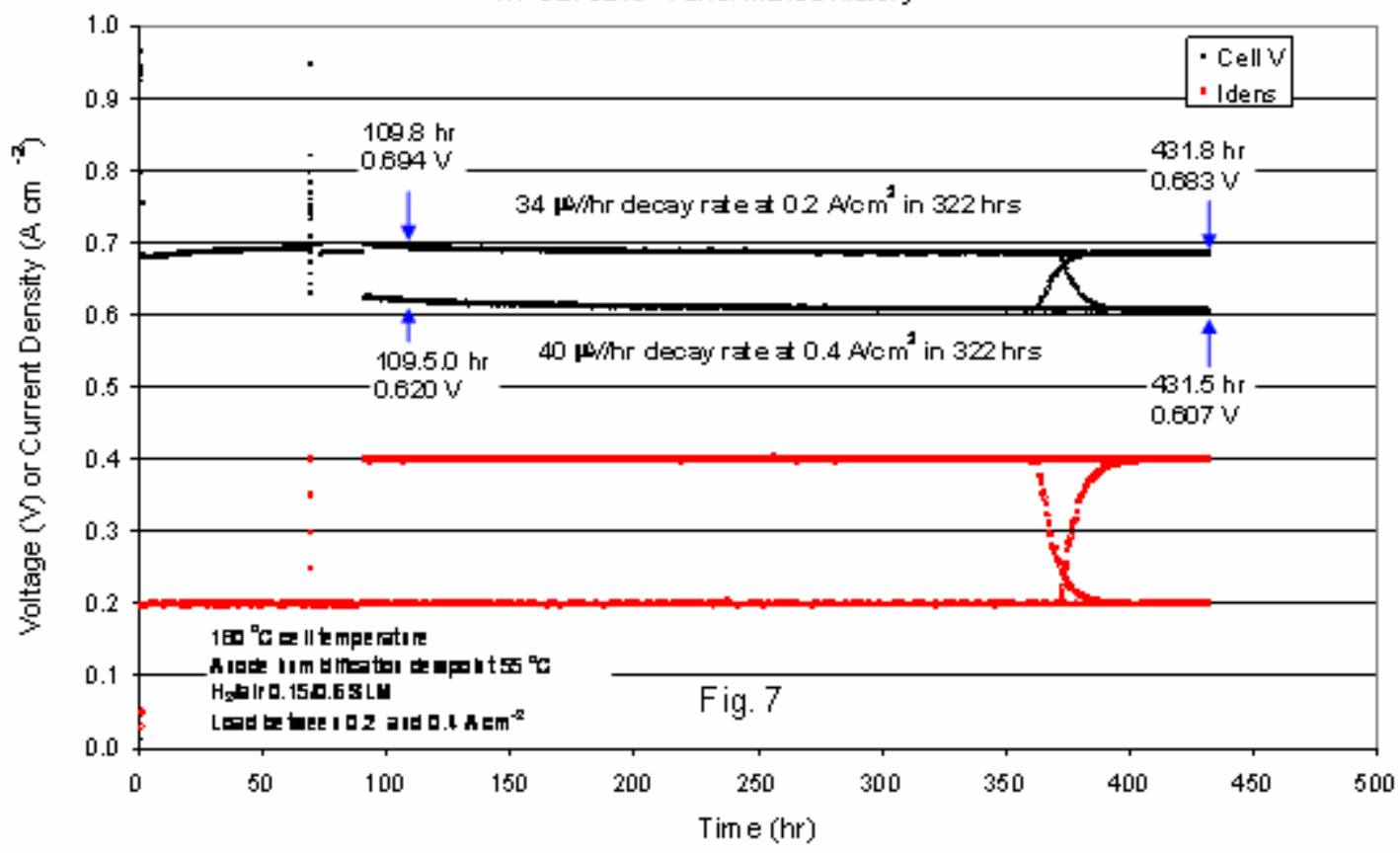

Figure 52: Cell 3245 Endurance Data

Constant load cells 3240 and 4241 had higher decay rates than other cells. This could be due to MEA-to-MEA variation, cell-to-cell variation, and station-to-station variation. The higher resistance was believed to be one of the possible contributing factors for cell 3240. The other two constant load cells 3242 and 3243 had very similar decay rates as load cycling cells 3244 and 3245 at current densities of 0.2 and $0.4 \mathrm{~A} / \mathrm{cm}^{2}$, respectively. All the decay rates were tabulated in Table 25 for easy comparison.

The overall testing has been successful, as it firmly demonstrated that load cycling did not cause higher voltage decay rate at $180^{\circ} \mathrm{C}$ cell temperature, which agrees with the conclusion obtained from cells tested at $160{ }^{\circ} \mathrm{C}$ reported last quarter.

\begin{tabular}{|c|c|c|c|c|c|c|}
\hline $\begin{array}{c}\text { Cell } \\
\text { number }\end{array}$ & 3240 & 3241 & 3242 & 3243 & 3244 & 3245 \\
\hline $\begin{array}{c}\text { Running } \\
\text { mode }\end{array}$ & $\begin{array}{c}0.2-0.4 \\
\mathrm{~A} / \mathrm{cm}^{2} \\
\text { Steady }\end{array}$ & $\begin{array}{c}0.2-0.4 \\
\mathrm{~A} / \mathrm{cm}^{2} \\
\text { Steady }\end{array}$ & $\begin{array}{c}0.4 \\
\mathrm{~A} / \mathrm{cm}^{2} \\
\text { Steady }\end{array}$ & $\begin{array}{c}0.2 \mathrm{~A} / \mathrm{cm}^{2} \\
\text { Steady }\end{array}$ & $\begin{array}{c}0.4 \\
\mathrm{~A} / \mathrm{cm}^{2} \\
\text { Cycling }\end{array}$ & $\begin{array}{c}0.2 \mathrm{~A} / \mathrm{cm}^{2} \\
\text { Cycling }\end{array}$ \\
\hline $\begin{array}{c}\text { Decay } \\
\text { rate } \\
(\mu \mathrm{V} / \mathrm{h}) \text { at }\end{array}$ & 65 & 36 & 31 & 34 \\
\hline
\end{tabular}




\begin{tabular}{|c|l|l|l|l|l|l|}
\hline $0.2 \mathrm{~A} / \mathrm{cm}^{2}$ & & & & & \\
\hline $\begin{array}{c}\text { Decay } \\
\text { rate } \\
(\mu \mathrm{V} / \mathrm{h}) \text { at } \\
0.4 \mathrm{~A} / \mathrm{cm}^{2}\end{array}$ & 55 & & 41 & 43 & 40 \\
\hline
\end{tabular}

Table 25: Decay Rate in About 400 hours of Testing $-180^{\circ} \mathrm{C}$

\section{Conclusions}

1. OCV had a significant negative impact on OCV itself and fuel cell performance. The decline was exponential; most of the loss occurred in the first 50 hours of exposure to OCV.

2. Both the cathode activation resistance and the mass transport resistance increased significantly in this process.

3. After 244.5 hours of OCV tests, the cathode Pt grain size increased to as much as 5.3 times of its original value, while the anode Pt grain size showed little change.

4. One cell was seriously damaged after running under reactant starvation condition at 452-hour time mark due to a lab event, and it showed much higher decay rate afterwards. These high decay rates were excluded from making comparison with other cells.

5. The decay rates showed quite high variation from cell to cell, but the decay rates of load cycling cells were in the range of steady state running cells, implying that load cycling itself did not accelerate decay rate.

6. Decay rates were higher at $0.4 \mathrm{~A} / \mathrm{cm}^{2}$ than at $0.2 \mathrm{~A} / \mathrm{cm}^{2}$ for all the cells.

7. The average decay rate at either 0.2 or $0.4 \mathrm{~A} / \mathrm{cm} 2$ became smaller with time.

8. Except for one cell, all the other five cells showed excellent and almost identical BOL performance.

9. The poor performing cell showed $1-\mathrm{kHz}$ impedance about $50 \%$ higher than other cells, and it is believed that the higher resistance was a major contributing factor to its lower BOL performance.

10. Two constant load cells showed very similar decay rates as the two load-cycling cells at 0.2 and $0.4 \mathrm{~A} / \mathrm{cm}^{2}$, respectively; while other two constant load cells showed apparently higher decay rates that the two load cycling cells.

11. The results indicated that load cycling did not cause higher voltage decay rates than at constant loads.

Task 7 and 8: $440-\mathrm{cm}^{2}$ MEA Test in Short Stack and Long-Term Characterization 
The module ran a total of 7200 hours and is currently undergoing autopsy. The overall degradation rate of the module was approximately $30 \mu \mathrm{V} / \mathrm{hr}$ with most of the losses attributed to station trips. Close inspection of the individual cell data shows both a significant difference in beginning of life voltage $(0.66-0.70)$ and a large difference in decay rates among cells $(8-54 \mu \mathrm{V} / \mathrm{hr})$. The onset of this spread could coincide with the stress relaxation properties of the MEA. That is, areas of over compression could begin to see membrane thinning, gas crossover and shorts. Another area being investigated is the temperature "stack-up" and whether areas of the MEA can see operating temperatures outside of specification. The possibility of interactions between the two factors is also being investigated.

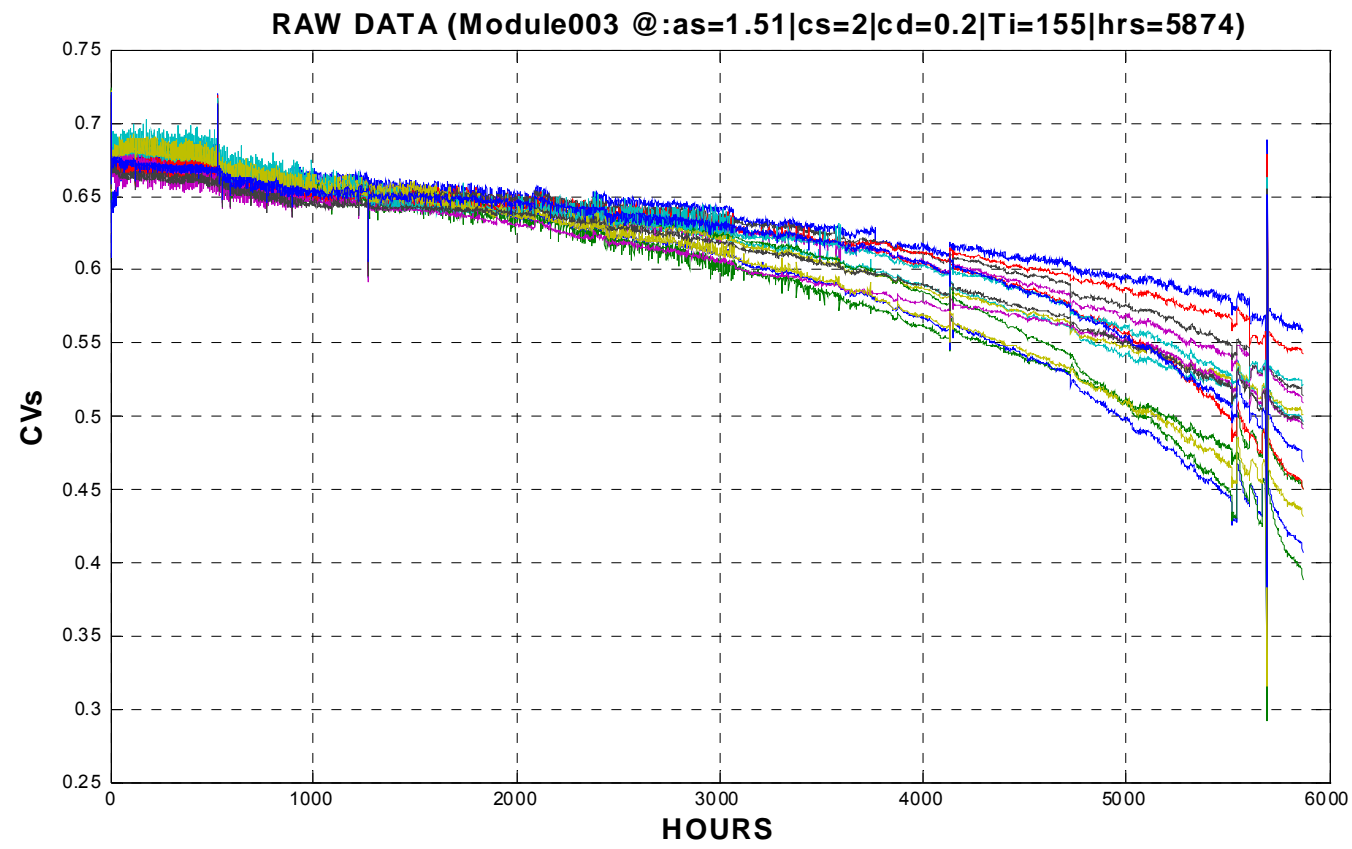

Figure 53: 16-Cell Module Endurance Run at 5874 Hours

A very promising result of this endurance testing are the several cells which displayed less than $10 \mu \mathrm{V} / \mathrm{hr}$ during the 8000 hour run. These will be studied as closely as the cells with ten times this degradation to uncover what is different in the cells.

\section{FOCUS 3 RESULTS: HARDWARE DEVELOPMENT AND DEMONSTRATION}

\section{Task 9-Acid Management}

As part of an earlier NIST program, Plug Power built a microflow reactor (MFR) test station at its facility in the Netherlands to evaluate phosphoric acid absorbents. This station, shown in Figure 1, was modified and debugged for the DOE program, in order 
to operate around the clock to support long-term testing. Phosphoric acid composition in the air flow is determined via an ion chromatograph programmed to sample automatically.

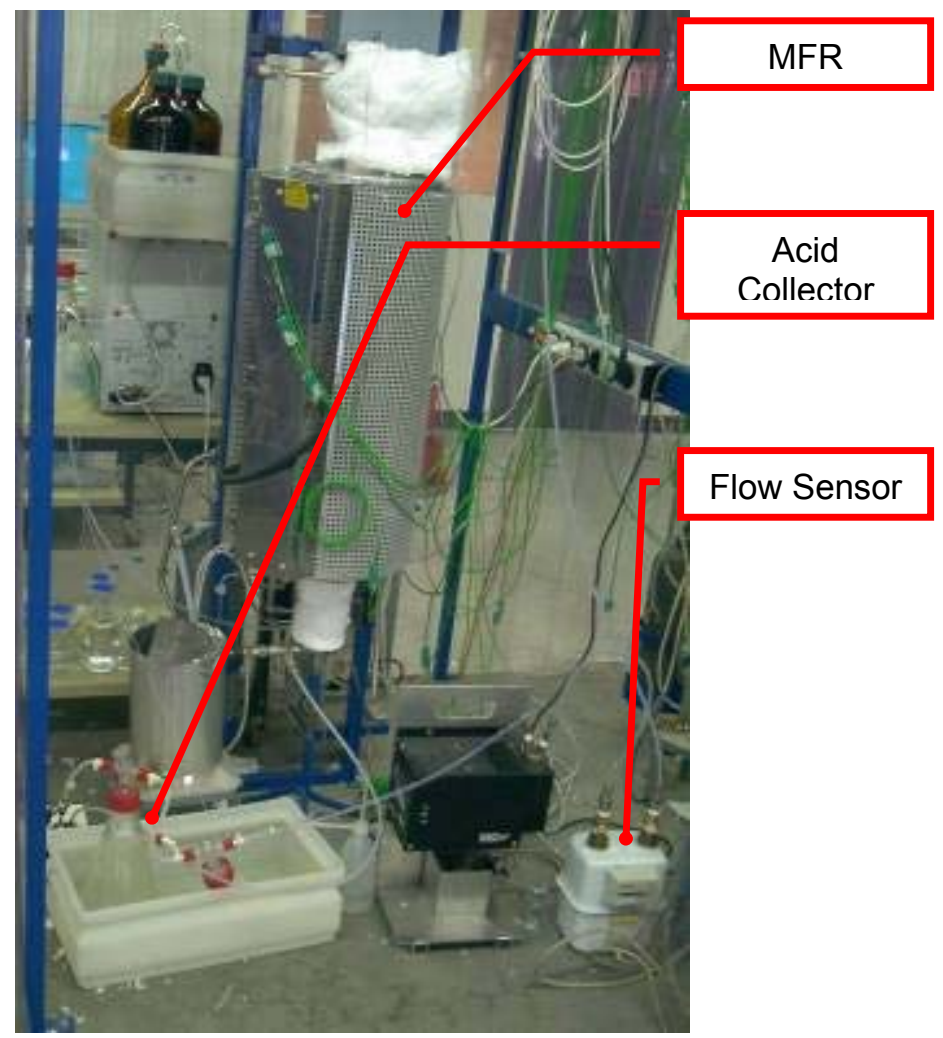

Figure 54: MFR Test Station to Evaluate Acid-absorbing Materials

Plug Power also built a comparable MFR test station at its Latham facility for the DOE program. On initial operation, humidified air was passed through a $50-\mathrm{cm}^{2} \mathrm{PBI}$ membrane.

Both test stations initially experienced difficulty maintaining outlet acid concentrations consistent with expectations. The cause of low outlet acid concentrations during steady-state operation was determined to be condensation and trapping of phosphoric acid in the system. When the system was restarted and reheated, steam washed the acid out of the lines, producing high outlet concentrations. The acid injection system was modified and the severity and magnitude of the accumulation was lessened.

Four tests were conducted:

1. A bubbler test, wherein humidified air was bubbled through phosphoric acid at $160-180^{\circ} \mathrm{C}$. The resultant humidified and acid-laden air saturated the absorbent. This test was critical in allowing us to compare the absorbency of phosphoric acid trap materials. Candidate materials included a commercially available absorbent material and a material for which this was a new application. 
2. Scaling up the $50-\mathrm{cm}^{2}$ test described above to larger active area sizes so that prototypical flows and volumes of absorbent can be used. This test allowed for sizing of the absorbent bed; i.e., quantifying how much acid the absorbent can retain and how fast can it absorb it.

3. Contamination of ATR/HTS catalysts using a module with MEAs of prototypical active area size. This test investigated the extent to which phosphoric acid was a contaminant within the fuel processor and allowed a tradeoff study to be performed between catalyst life and trap size.

4. A static test wherein phosphoric acid was combined with the absorbent material in a container and then baked. This allowed the resultant phosphoric acid/absorbent mixture to be chemically analyzed to determine if hazardous materials would be formed.

Tests were conducted to understand the effect on phosphoric acid on the autothermal reformer (ATR) catalyst. A stack module with MEAs of prototypical active area size was used to contaminate ATR/HTS catalysts. This test investigated the extent to which phosphoric acid is a contaminant within the fuel processor and allowed a tradeoff study to be performed between catalyst life and trap size.

Preliminary results from a 500-hour exposure showed some catalyst temperatures increasing from inlet to outlet over time, which is typically indicative of deactivation. Collection of water at the outlet of the ATR showed that phosphoric acid was indeed getting adsorbed within the catalyst bed. The average bed inlet acid concentration was $7.6 \mathrm{ppm}$, while the outlet concentration was $\sim 0.7-0.8 \mathrm{ppm}$.

The observed behavior of phosphoric acid within the MFR test station on start-up and shutdown will be considered in the development of the operating procedures for future test station and PBI-based fuel cell systems. By isolating the stack from the system, acid loss due to start-up and shutdown cycles should be eliminated.

To check the effects of PA poisoning, an ATR catalyst was aged in a microflow reactor by being exposed to a phosphoric acid source. After the catalyst surpassed end-of-life characteristics, the catalyst was removed and analyzed for phosphoric acid contamination. This contamination pattern showed that phosphoric acid was present in the inlet of the catalyst with highest concentrations, and at low concentrations at the outlet of the catalyst. The phosphorus was also present at the top layer of the catalyst surface, thus masking all the catalyst beneath the phosphorus deposition.

Phosphoric acid adsorbent material was then run downstream of two 16-cell modules. The purpose of this testing was to obtain accelerated "clogging" effects on the material. Since we have observed that phosphorus adsorbs only on the surface, the density and aspeciation of the cake needs to be determined. As cake material accumulates, the flow area would decrease and "end of life" of the adsorbent would be reached. Thus far, small amounts of cake formation have been observed, and it appears that it would be necessary to run for months before significant cake formations are demonstrated.

For acid trap materials, extruded ceramic monoliths are preferable to pelletized beds for the following reasons: 
1. Void fraction of the monolith is approximately twice that of the pelletized bed. Acid only coats and does not penetrate the pellets, therefore for an equivalent volume, acid removal capacity of the monolith would be double that of the pellets.

2. Pressure drop of monolithic materials is orders of magnitude lower.

3. Much better consistency expected due to symmetry of material and no settling effects.

Experiments to determine the effectiveness of an acid trap design were performed on High-Temperature Module HT-MOD-003. The traps are designed using a Corning cordierite monolith, with square pore geometry. The mechanism for filtration is impingement of the acid on the surface of the monolith. For this reason 2 mesh sizes were employed. The first, a 6 " section of 100 pore/in ${ }^{2}$, followed by a 6 " section of 400 pore/in ${ }^{2}$. The theory being that as the first section clogged, sufficient open are would be maintained to allow flow with minimal pressure drop. The second section would then provide more fine filtering.

The trap elements were housed in a section of $1 \frac{1 / 4}{4} 316 \mathrm{~L}$ SS tubing, and secured and sealed using a ceramic wool. See Figure 55. The traps were installed on the anode and cathode exhaust ports of HT MOD-003, built as a 16 cell, with full scale $440 \mathrm{~cm}^{2}$ active area plates in a 4 cell / cooler configuration. The module ran under dry $\mathrm{H}_{2}$ and air, $1.2 \& 2.0$ stoich, and a nominal coolant temperature of $160 \mathrm{C}$. The module at ran at $.2 \mathrm{~A} / \mathrm{cm}^{2}$ current density for approximately $8000 \mathrm{hrs}$ under these conditions.

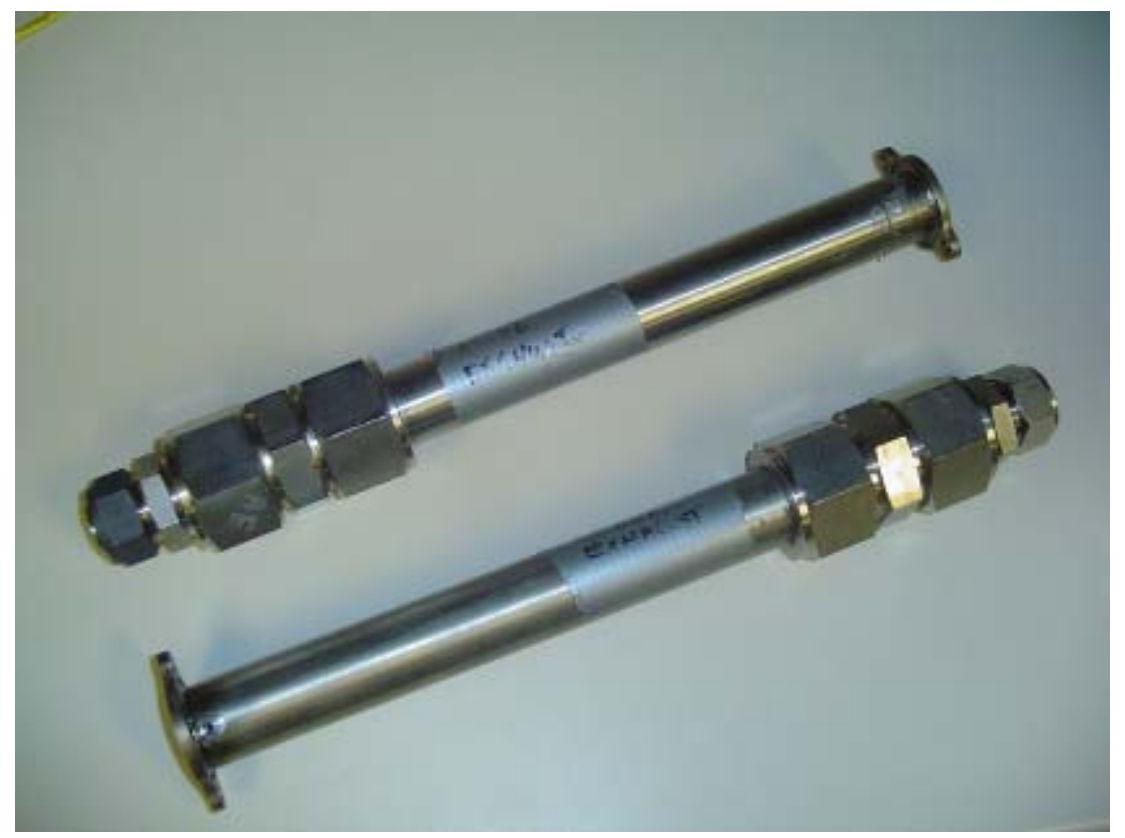

Figure 55: Acid Trap Housings

The traps were tested for pressure drop under same conditions as above except using flows for $29 \%$ Reformate, equivalent to $.05, .10$ and $.2 \mathrm{~A} / \mathrm{cm} 2$, and measured DP respectively for anode $.01, .58 \& .98 \mathrm{mbar}$, and cathode $.50, .98$, and $1.57 \mathrm{mbar}$. 


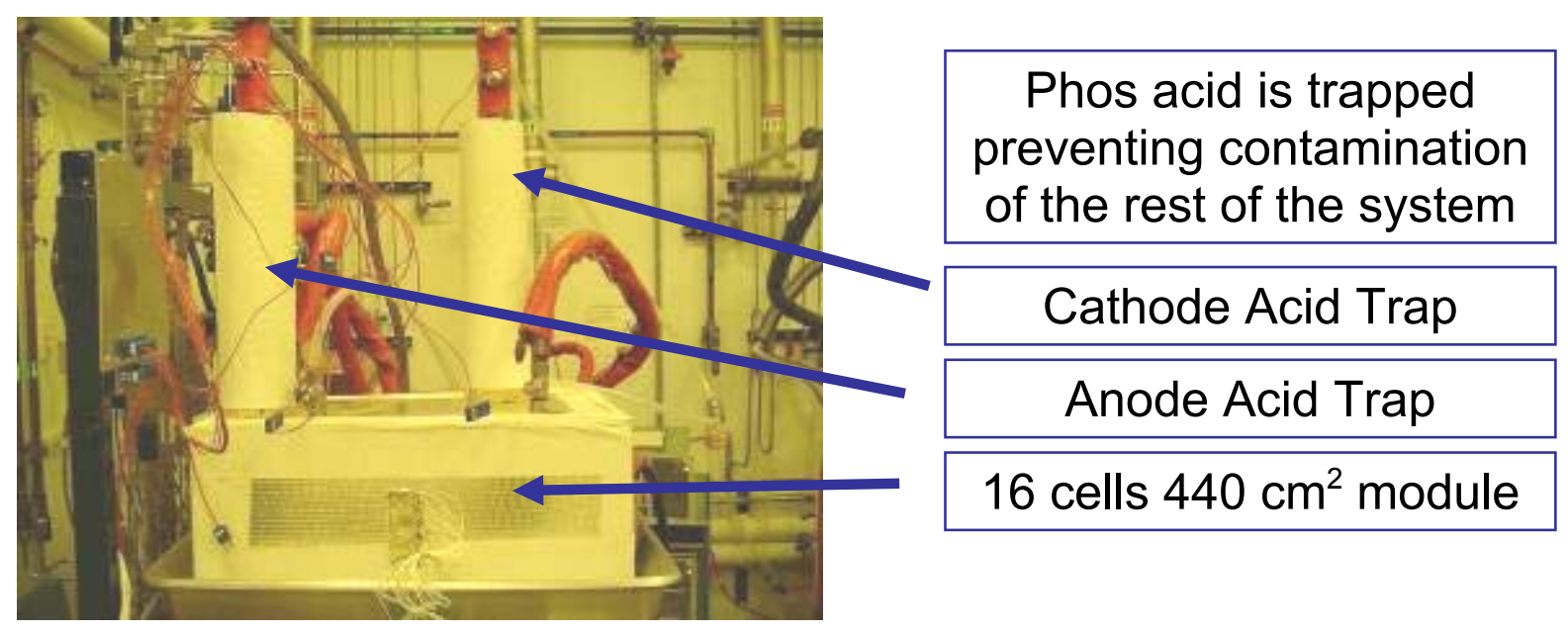

Figure 56: Acid Traps Being Tested in Modules

Upon removal of the traps from the module a visual inspection showed $0 \%$ blockage of any of the pores in either the anode of cathode monoliths. The $316 \mathrm{~L}$ casing did show a brownish residue in the anode inlet and green deposits in the cathode case. These deposits are currently out for analysis.

The monolith was then sectioned in 1" sections and inspected visually. See Figure 57. $0 \%$ blockage was observed for all sections of both cathode and anode. The 1 " sections are currently being analyzed for acid content by titration. 


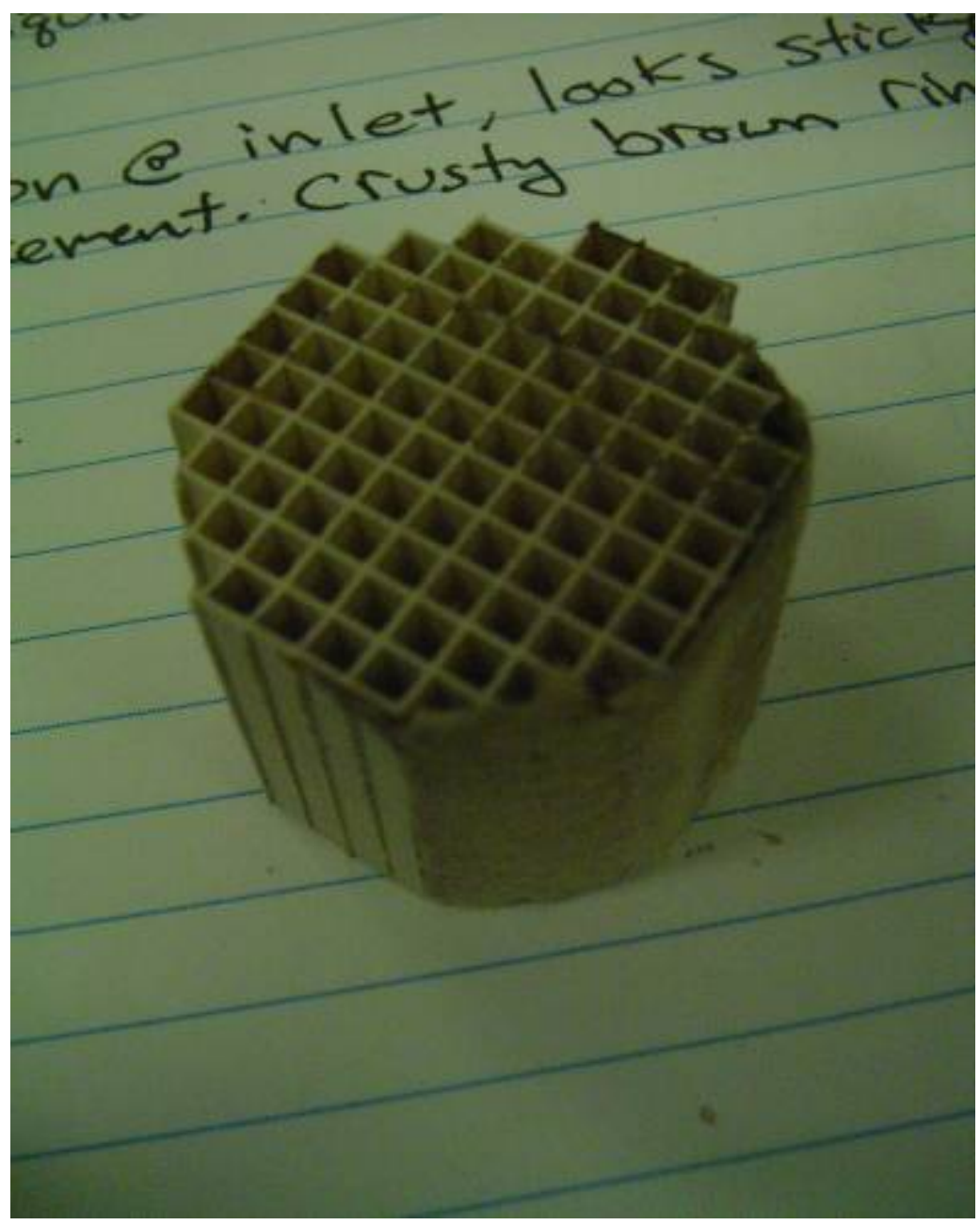

Figure 57: One-Inch Monolith Sections

Based on the preliminary results, the trap design features will be reevaluated. Single or composite mesh size components, case construction and monolith volume, aspect ratio and geometry.

The remaining inputs required to complete the design are the results from the titration, system allowable pressure drop and packaging constraints. 


\section{Task 10-PBI-Specific Flow Field}

Flow field modeling. Because $\mathrm{PBI}$ membranes are run at temperatures about the boiling point of water, no liquid water is present in the cells. The absence of two-phase flow in the flow field of the bipolar plates suggests that the optimum design of these plates for high-temperature cells will differ from the plates used for low-temperature PEM cells. In attempting to determine the optimum plate design for PBI cells using analytical and empirical tools, Plug Power centered its work on laboratory-sized cells (50- $\mathrm{cm}^{2}$ active area).

A computational fluid dynamics (CFD) analysis was performed on flow fields with straight channels to analyze the effect of flow field geometry on the behavior of the reactants. The computational domain for this work is shown in Figure 3. The independent parameters that were varied were the channel-to-land width ratio, the channel width, the channel flow area, and the manifold configuration. The dependent geometric dimensions and the independent variables that define them are listed in Figure 4. Nine numerical experiments or analyses were performed. The values of each of the independent variables for each of these analyses are shown in Table 2. Gas properties were based on a mixture of 48 volume $\%$ hydrogen and 52 volume $\%$ nitrogen.
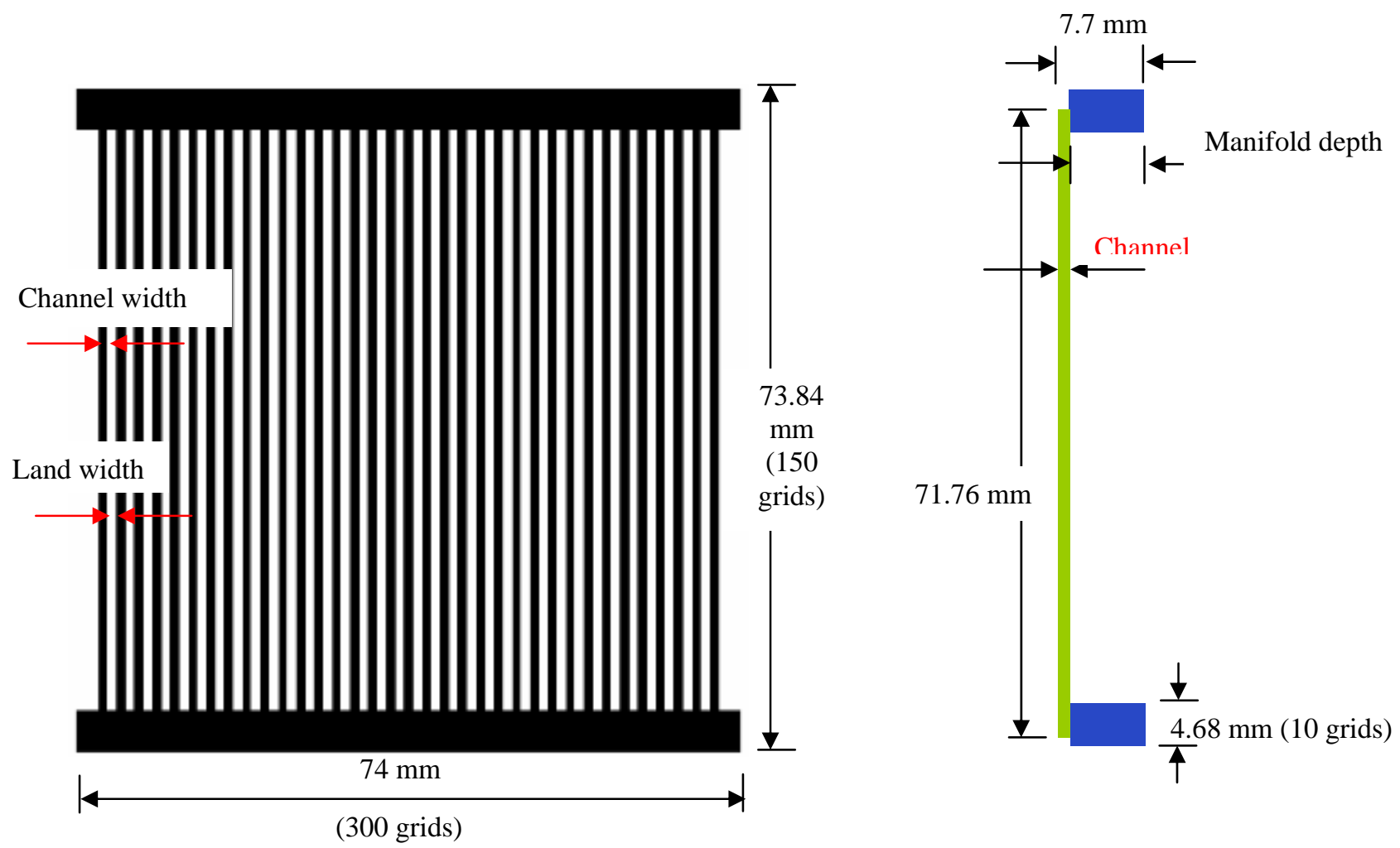

Figure 58: Computational Domain for the Numerical Flow Field Simulation Studies 


\section{Independent factors:}

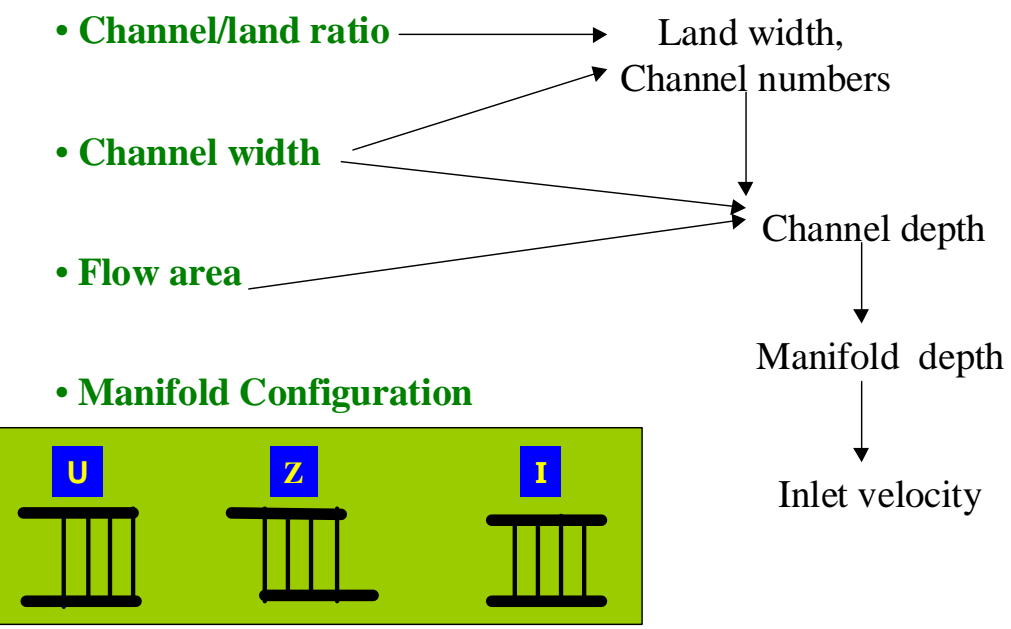

Figure 59: Flow Field Design Factors

\begin{tabular}{|c|c|c|c|c|}
\hline \multicolumn{5}{|c|}{ Values of independent parameters in flow field simulations. } \\
\hline $\begin{array}{c}\text { Experiment } \\
\text { Number }\end{array}$ & $\begin{array}{c}\text { Channel/land } \\
\text { Ratio }\end{array}$ & $\begin{array}{c}\text { Channel width } \\
(\mathbf{m m})\end{array}$ & $\begin{array}{c}\text { Flow area } \\
\left(\mathbf{m m}^{\mathbf{2}}\right)\end{array}$ & $\begin{array}{c}\text { Manifold } \\
\text { Configuration }\end{array}$ \\
\hline 1 & 1.0 & 1.00 & 25 & $\mathrm{U}$ \\
\hline 2 & 1.0 & 2.00 & 50 & $\mathrm{Z}$ \\
\hline 3 & 1.0 & 3.00 & 75 & $\mathrm{I}$ \\
\hline 4 & 2.0 & 1.00 & 50 & $\mathrm{I}$ \\
\hline 5 & 2.0 & 2.00 & 75 & $\mathrm{U}$ \\
\hline 6 & 2.0 & 3.00 & 25 & $\mathrm{Z}$ \\
\hline 7 & 3.0 & 1.00 & 75 & $\mathrm{Z}$ \\
\hline 8 & 3.0 & 2.00 & 25 & $\mathrm{I}$ \\
\hline 9 & 3.0 & 3.00 & 50 & $\mathrm{U}$ \\
\hline
\end{tabular}

Table 26: Flow Field Design Factors

Figures 60 through 65 illustrate the effects of flow area, manifold configuration, flow rate, and manifold size on pressure distribution along the channels. Figures 66 and 67 illustrate the effects of the independent parameters on pressure distribution between the channels. The mean pressure differential along the channels for each simulation is provided in Table 27. 

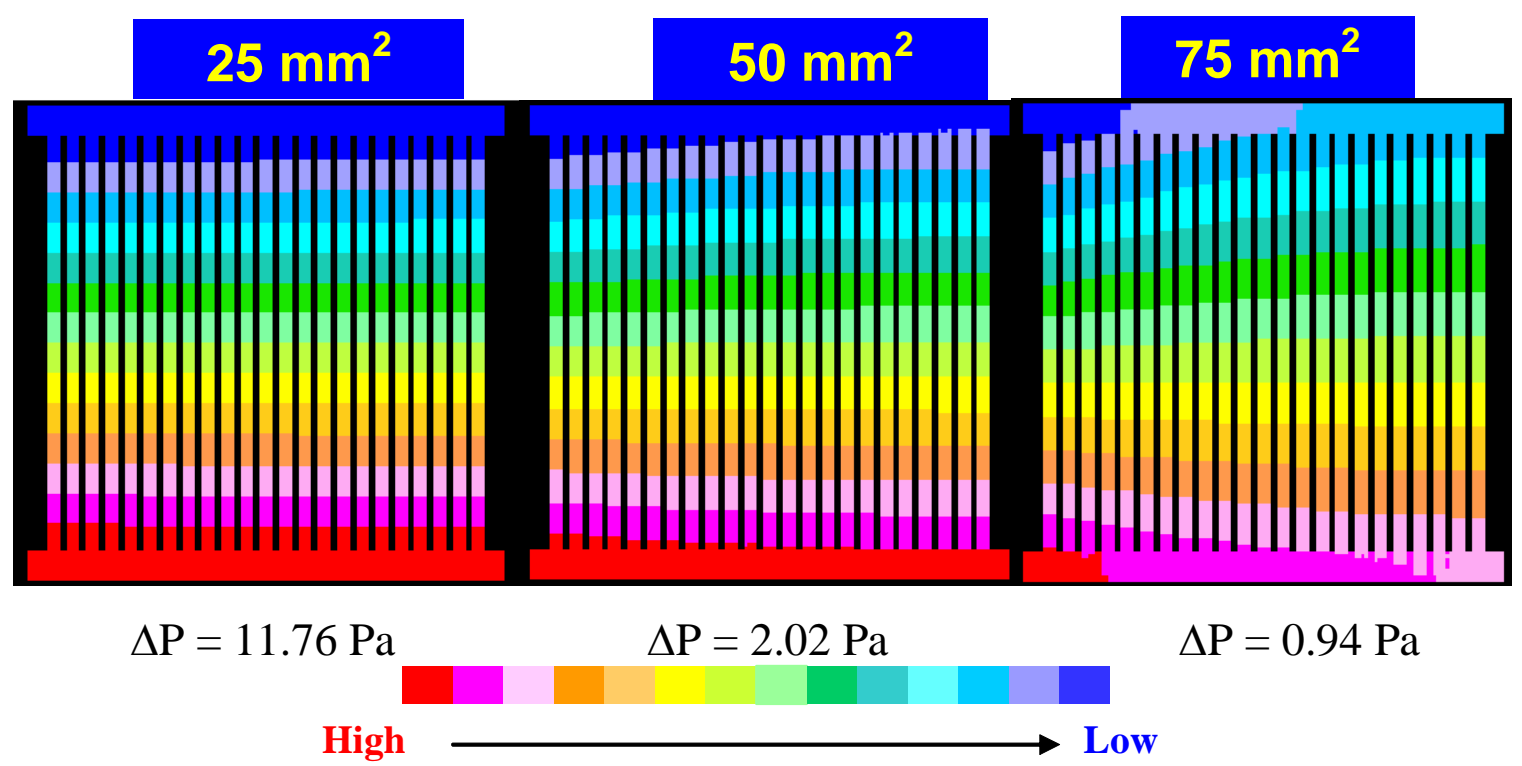

Figure 60: Effect of Total Flow Area on Reactant Pressure Drop Along the Channels

Figures represent experiments 11,10 , and 5 (Table 2 ) with channel-to-land width ratio of 2.0, channel width of $2 \mathrm{~mm}$, and U-flow manifold configuration.

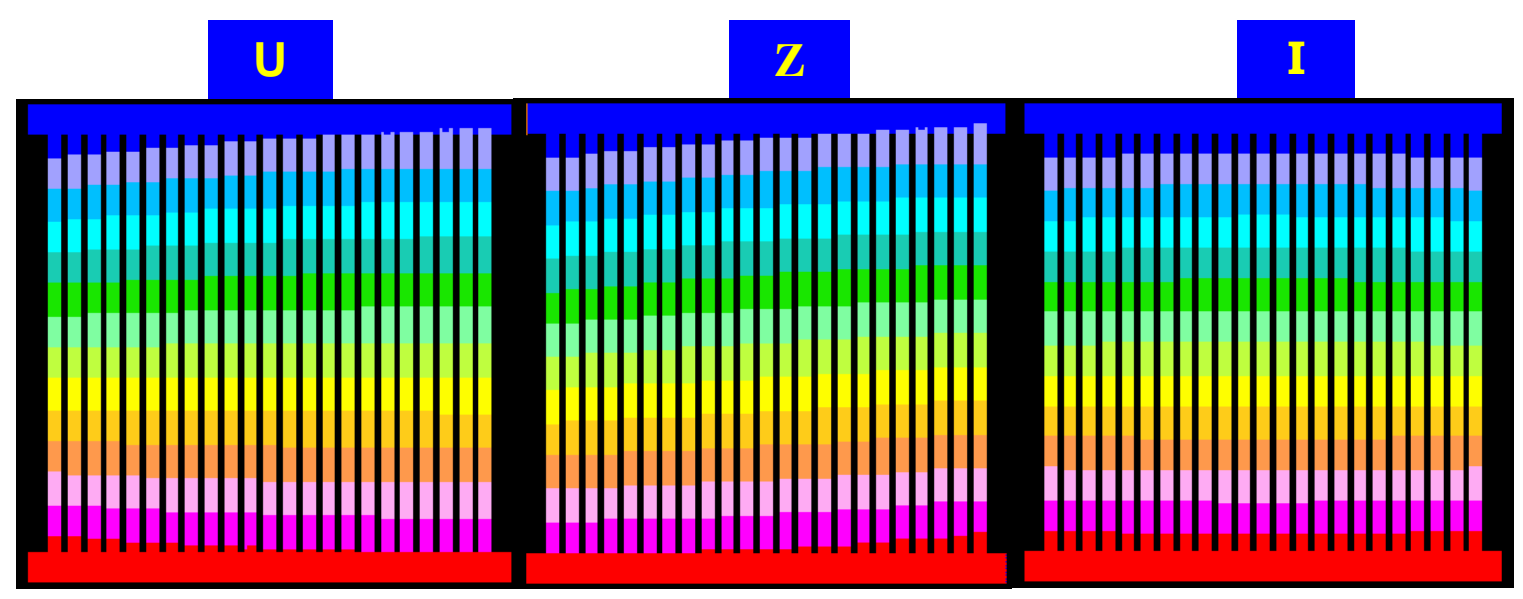

$\Delta \mathrm{P}=1.88 \mathrm{~Pa}$

Figure 61: Effect of Manifold Configuration on Reactant Pressure Drop Along the Channels

Figures represent experiments 10,12 , and 13 (Table 2) with channel-to-land width ratio of 2.0 , channel width of $2 \mathrm{~mm}$, and flow area of $50 \mathrm{~mm}^{2}$. 


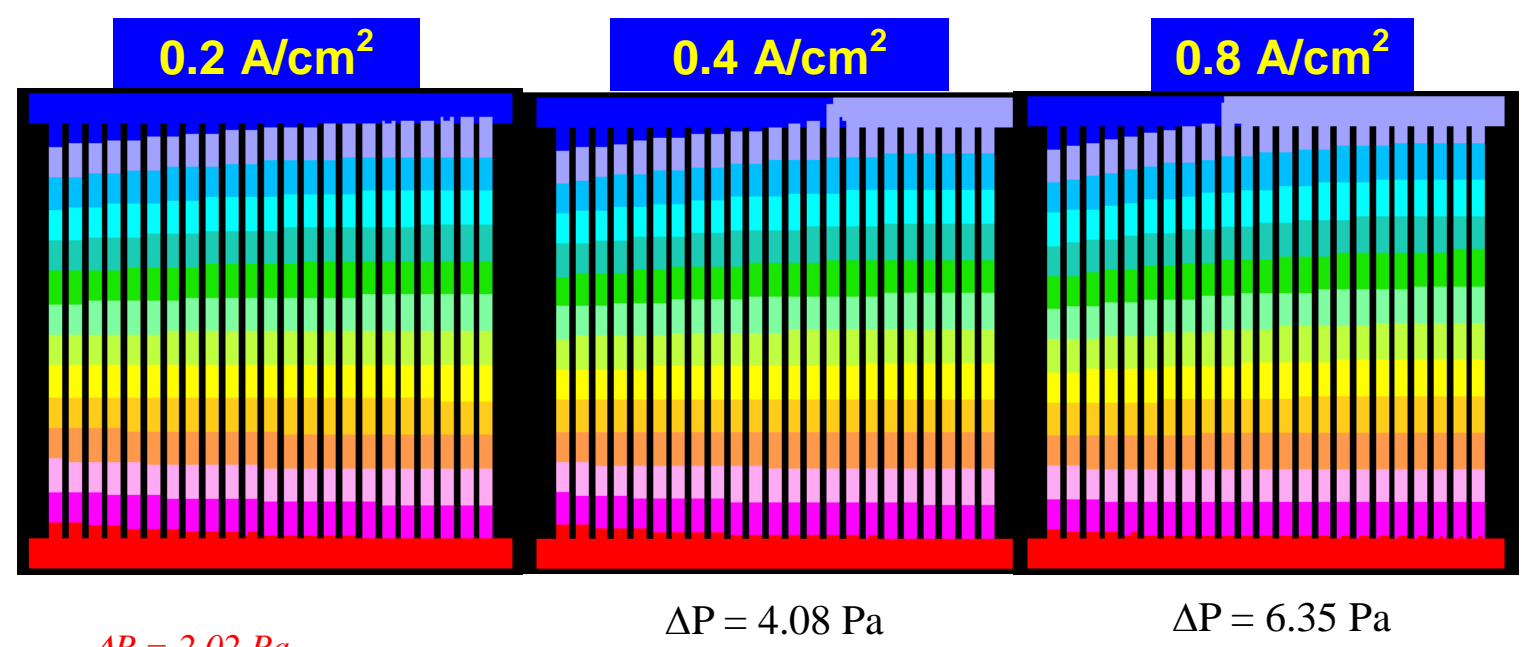

Figure 62: Effect of Flow Rate on Reactant Pressure Drop Along the Channels

Flow rate is proportional to current density. Figures represent varied flow rates for experiment 10 (Table 2) with channel-to-land width ratio of 2.0, channel width of $2 \mathrm{~mm}$, flow area of $50 \mathrm{~mm}^{2}$, and U-flow manifold configuration.

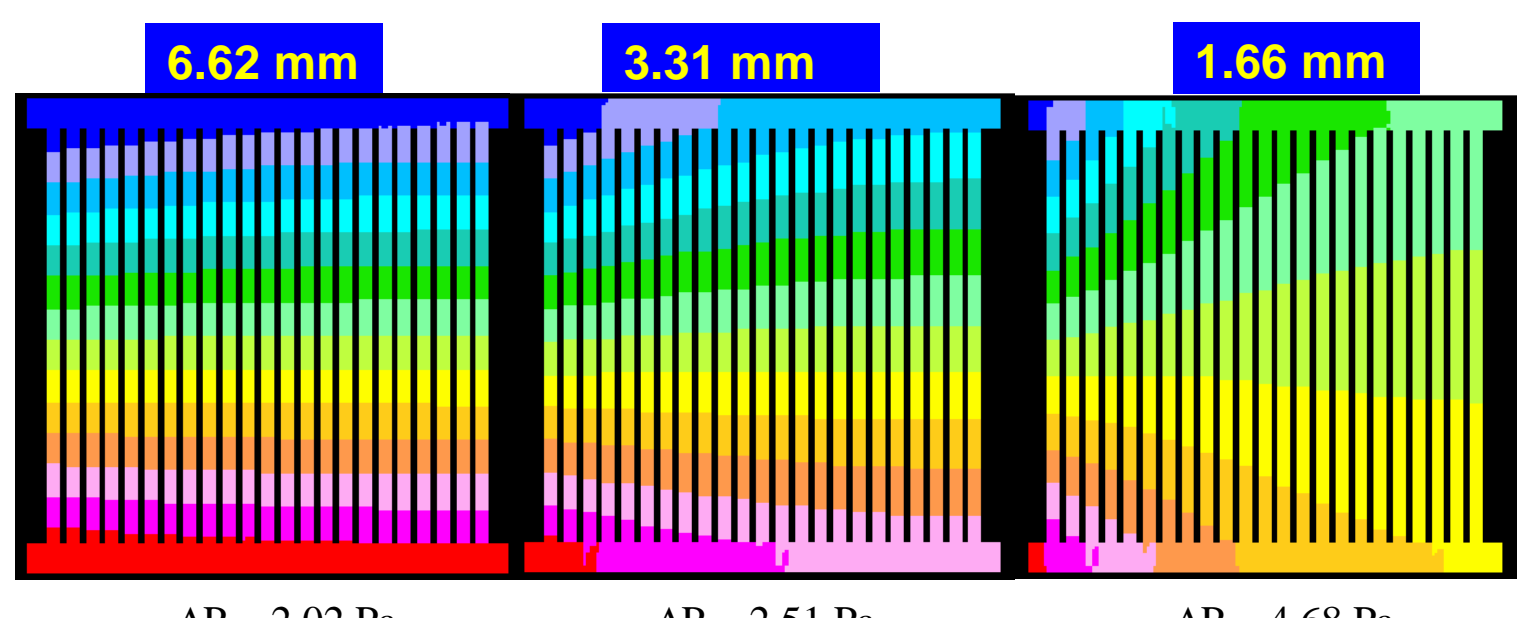

$\Delta \mathrm{P}=2.02 \mathrm{~Pa}$

$\Delta \mathrm{P}=2.51 \mathrm{~Pa}$

$\Delta \mathrm{P}=4.68 \mathrm{~Pa}$

Figure 63: Effect of Manifold Size on Reactant Pressure Drop Along the Channels 
Flow rate is proportional to current density. Figures represent varied manifold sizes for experiment 10 (Table 2) with channel-to-land width ratio of 2.0, channel width of $2 \mathrm{~mm}$, flow area of $50 \mathrm{~mm}^{2}$, and U-flow manifold configuration.

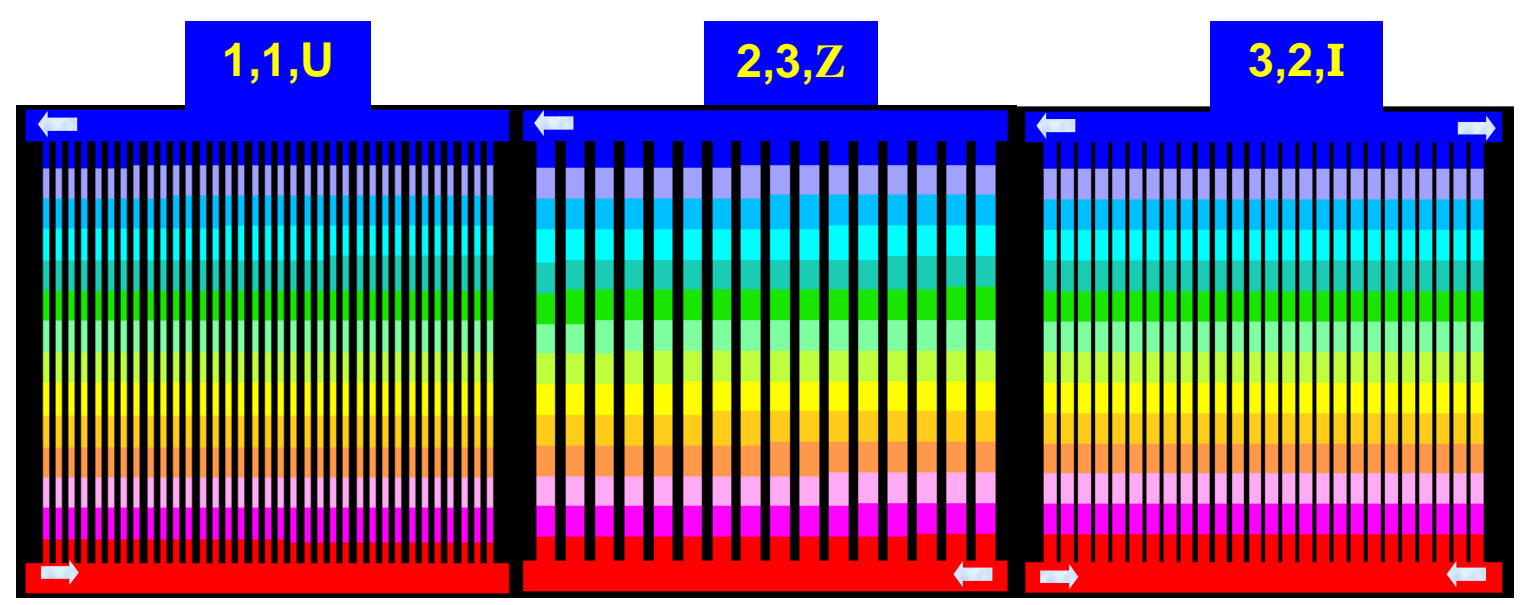

$\Delta \mathrm{P}=10.08 \mathrm{~Pa}$

$\Delta \mathrm{P}=10.88 \mathrm{~Pa}$

$\Delta \mathrm{P}=9.29 \mathrm{~Pa}$

Figure 64: Effect of Design Factors on the Pressure Distribution Between Channels

Figures represent experiments 1, 6, and 8 (Table 2) with a flow area of $25 \mathrm{~mm}^{2}$. Figure headings represent the channel-to-land width ratio, the channel width $(\mathrm{mm})$, and the manifold configuration for each case.

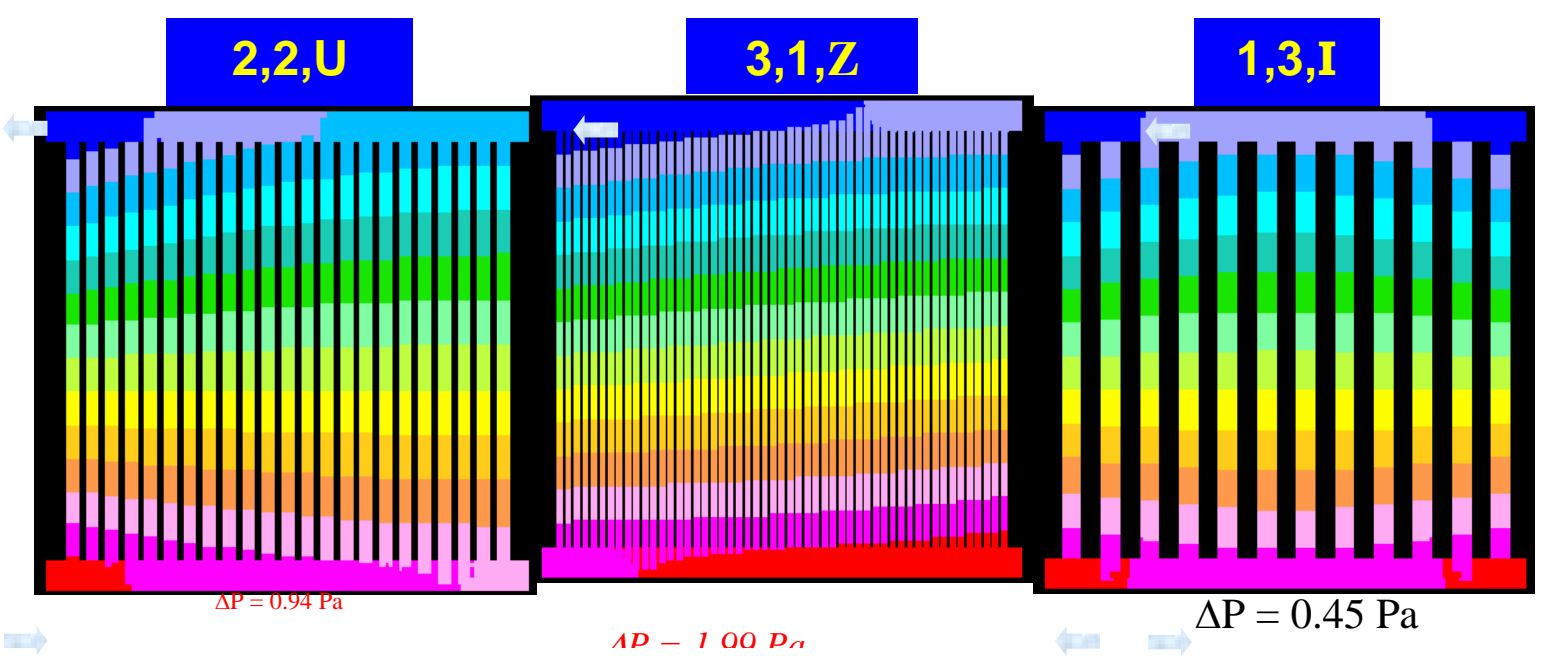

Figure 65: Effect of Design Factors on the Pressure Distribution Between Channels. 
Figures represent experiments 5, 7, and 3 (Table 2) with a flow area of $75 \mathrm{~mm}^{2}$. Figure headings represent the channel-to-land width ratio, the channel width $(\mathrm{mm})$, and the manifold configuration for each case, respectively.

The ratio of the minimum and average velocities, the ratio of the maximum and average velocities, and the ratio of the minimum and maximum velocities within the flow field characterize the flow distribution. Table 27 presents reactant flow distribution data for each of the simulations.

\begin{tabular}{|c|c|c|c|c|c|c|c|}
\hline \multicolumn{10}{|c|}{$\begin{array}{c}\text { Flow field simulation results }- \text { mean channel pressure drop and flow distribution } \\
\text { data. Plate feature data for each experiment are provided in Table 2. }\end{array}$} \\
\hline $\begin{array}{c}\text { Expt. } \\
\text { No. }\end{array}$ & $\begin{array}{c}\text { Mean } \\
\text { channel } \\
\text { pressure } \\
\text { drop (Pa) }\end{array}$ & $\begin{array}{c}\text { Minimu } \\
\mathbf{m} \\
\text { velocity } \\
(\mathbf{m} / \mathbf{s})\end{array}$ & $\begin{array}{c}\text { Maximum } \\
\text { velocity } \\
\mathbf{( m / s )}\end{array}$ & $\begin{array}{c}\text { Averag } \\
\mathbf{e} \\
\text { velocit } \\
\mathbf{y}(\mathbf{m} / \mathbf{s})\end{array}$ & $\begin{array}{c}\text { Vmin } \\
\text { Vavg } \\
(\%)\end{array}$ & $\begin{array}{c}\text { Vmax } \\
\text { Vavg } \\
(\%)\end{array}$ & $\begin{array}{c}\text { Vmin } \\
\text { Vmax } \\
(\%)\end{array}$ \\
\hline 1 & 10.08 & 0.240 & 0.245 & 0.241 & 99.6 & 101.7 & 98.0 \\
\hline 2 & 1.41 & 0.115 & 0.120 & 0.116 & 99.1 & 103.4 & 95.8 \\
\hline 3 & 0.45 & 0.074 & 0.085 & 0.078 & 94.9 & 109.0 & 87.1 \\
\hline 4 & 3.15 & 0.118 & 0.118 & 0.118 & 100.0 & 100.0 & 100.0 \\
\hline 5 & 0.94 & 0.074 & 0.097 & 0.081 & 91.4 & 119.8 & 76.3 \\
\hline 6 & 10.88 & 0.231 & 0.231 & 0.231 & 100.0 & 100.0 & 100.0 \\
\hline 7 & 1.99 & 0.079 & 0.082 & 0.080 & 98.8 & 102.5 & 96.3 \\
\hline 8 & 9.29 & 0.243 & 0.243 & 0.243 & 100.0 & 100.0 & 100.0 \\
\hline 9 & 2.13 & 0.111 & 0.123 & 0.116 & 95.7 & 106.0 & 90.2 \\
\hline
\end{tabular}

Table 27: Flow Field Design Factors

The results of the simulations of straight channels led to the following conclusions:

1. Total flow area affects pressure drop along and flow uniformity between the channels. As the flow area increases, the pressure differential decreases, consistent with fluid dynamics predictions, and there is less uniform flow from channel to channel.

2. As the channels become narrower, the pressure drop along the channels becomes greater. Channel width does not appear to have any impact on flow distribution within the flow field.

3. The channel-to-land ratio does not appear to have a significant impact on flow distribution. This parameter is expected to have a significant effect on reactant diffusion across the lands and on current conduction from the GDL to the plate. 
4. Channel-to-channel flow uniformity is greatest with the Z-flow manifold configuration.

5. The size of the manifold has a significant effect on flow distribution within the flow field. The current manifold is large enough to support a uniform flow distribution.

2-D Electrochemical model. Matlab was used to visualize the results of an Excel/Visual Basic two-dimensional (2-D) electrochemical model of the plate flow field. This model was used in conjunction with past modeling and experimental work to optimize the flow field design for PBI-based MEAs. Electrochemical modeling was of particular interest because previous modeling considered only thermal-hydraulic parameters and there was a significant difference between numerical and empirical results.

This model included pressure, temperature, hydrogen and oxygen mole fractions, $\mathrm{CO}$ mole fraction, and current density. It assumed reactant flows are pressure-driven, accounted for water diffusion, and neglected channel-to-channel reactant diffusion, which was found to be of low significance.

Figure 66 illustrates one set of flow field configurations modeled, in which the two reactants enter the cells in from opposite ends of the plates. The nominal operating conditions modeled were a current density of $0.25 \mathrm{~A} / \mathrm{cm}^{2}, 1.15$ anode stoichs, 1.33 cathode stoichs, and a temperature of $183^{\circ} \mathrm{C}$. The resulting distributions of current, hydrogen, and oxygen are shown in Figure 67 . These results clearly illustrate large variations in reactant distribution and current production. In fact, in some regions, the cell is fuel-starved, which would lead to damage and reduced performance.
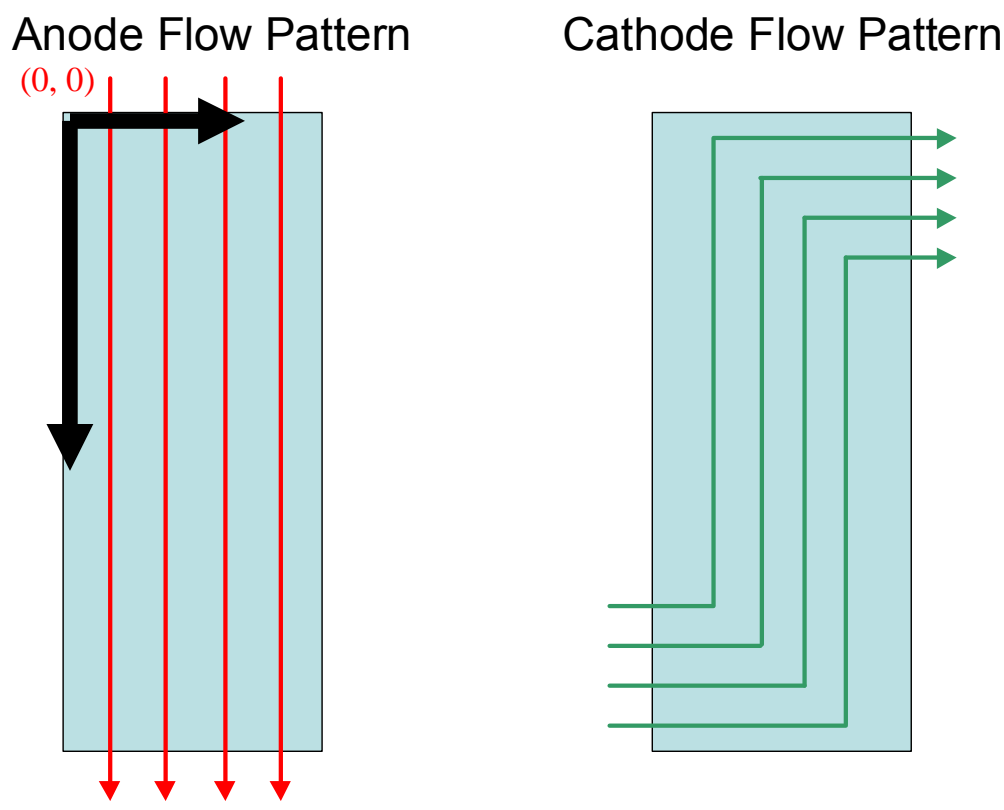

Figure 66: Example of Modeled Flow Field Configurations 


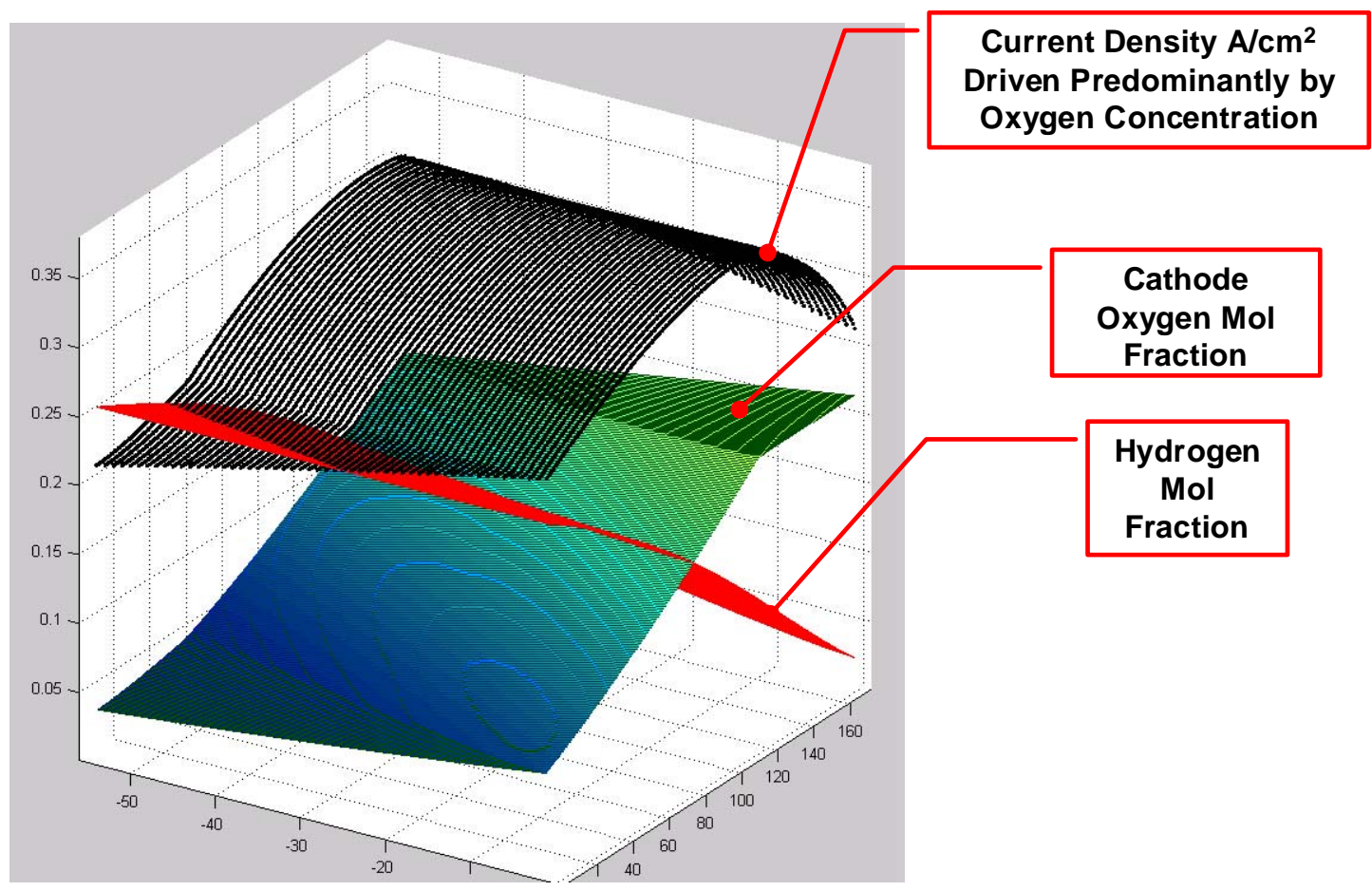

Figure 67: Current, Hydrogen, and Oxygen Distribution in a Cell

The results of this modeling work confirmed the following:

1. Extensive variations in reactant concentration and current density can be present in each cell.

2. These variations are strongly coupled to the flow field design.

3. These variations can result in regions of fuel starvation, which is known to lead to permanent cell damage.

4. Temperature and pressure distributions also vary within the cell.

By modifying the flow field design, we demonstrated numerically that a more uniform distribution of current density is achievable not only by appropriate flow field design (e.g., number and dimensions of channels, number of bends in the channels), but also by varying the flow field design on each plate. 
Flow Field Optimization. The 2-D electrochemical model of the plate flow field was exercised with eight different flow field configurations to optimize the reactant flow path. The decision was made to minimize the variability in anode stoichiometry over the flow field area. Figure 68 indicates that configurations 1 and 2 offer a significant advantage in anode stoich uniformity. Configurations 3 and 6 , though not possessing optimal anode stoich uniformity, are the next best choices due to the advantage of reduced pressure drop through the stack.

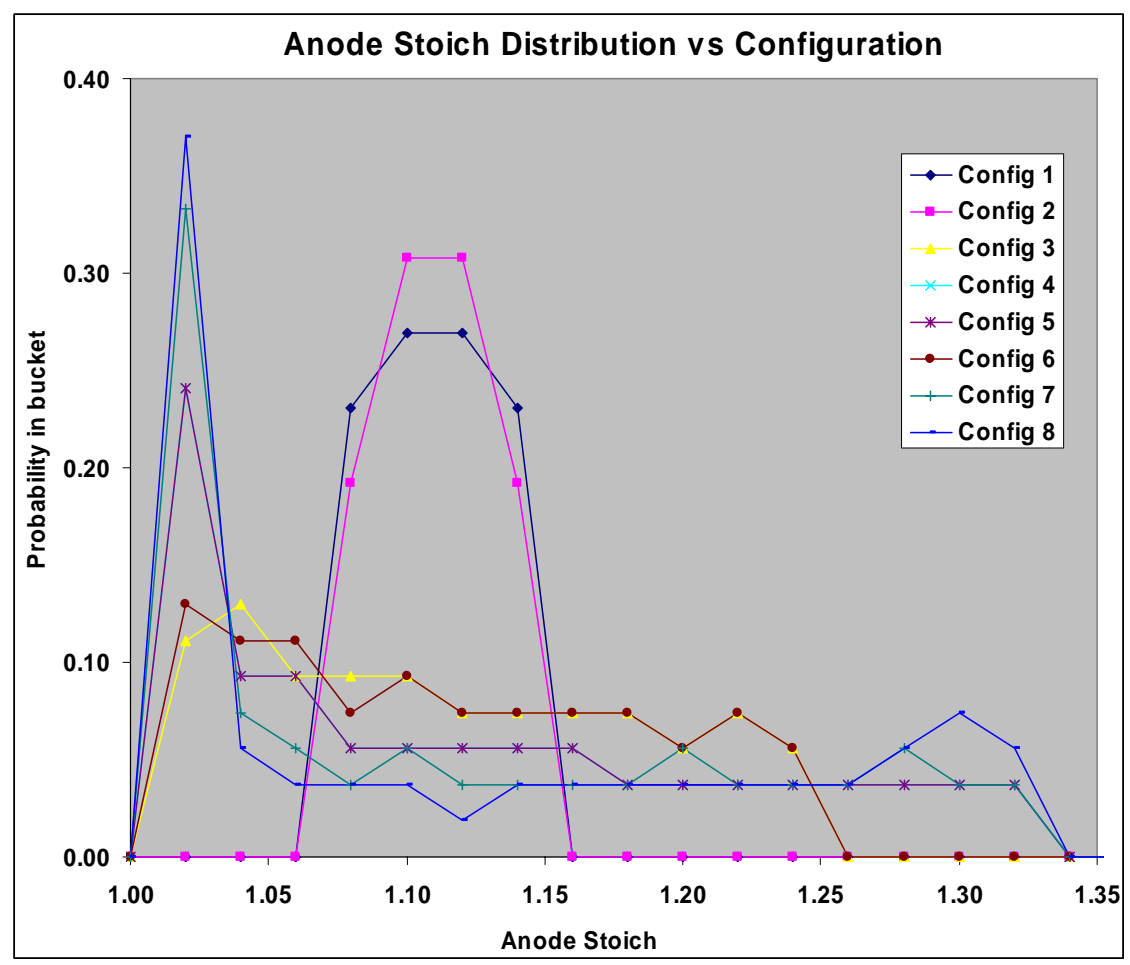

Figure 68: Anode Stoich Distribution and Configuration

A CFD model was created and exercised to evaluate the feasibility of converting the current double-pass baseline stack hardware to a single pass flow field. The initial model was developed for a single cell, and results confirmed uniform flow distribution in both single and double pass configurations.

The modeling result shows that the variation of flow rate between channels is less than $1.5 \%$ at $0.6 \mathrm{~A} / \mathrm{cm} 2$, and less than $0.3 \%$ at $0.1 \mathrm{~A} / \mathrm{cm} 2$. Double pass has slightly more uniform distribution than single pass (Figure 6). 

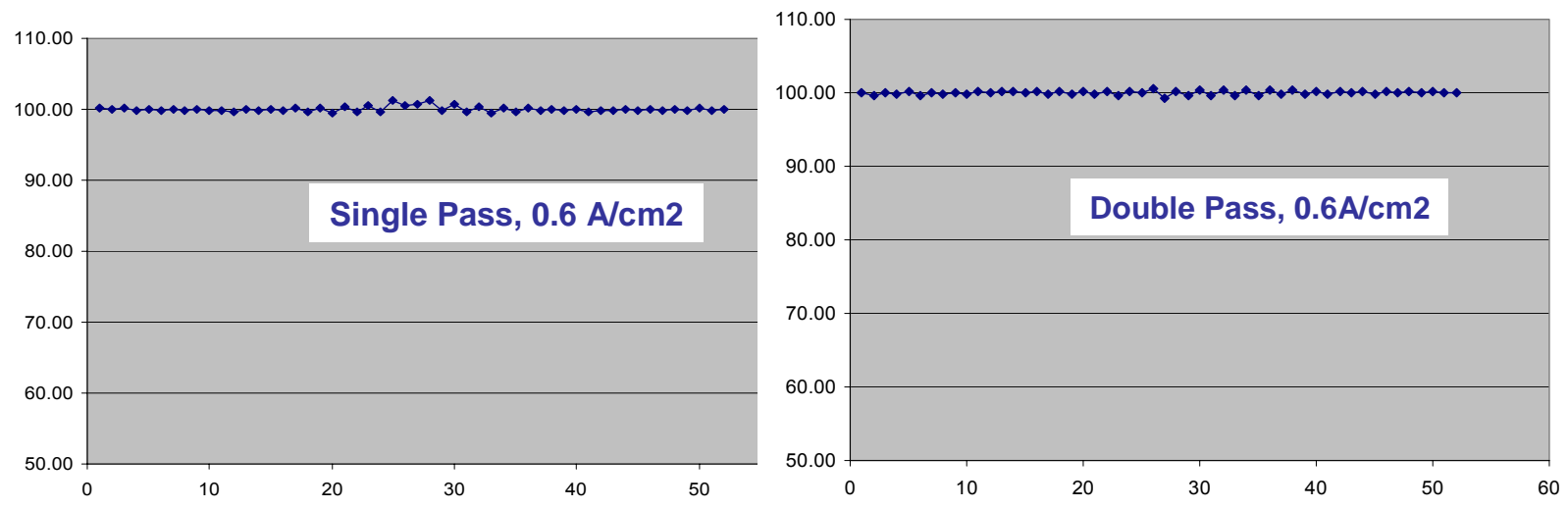

Figure 69: Variation of Flow Rate

Robust Optimization Testing. Robust design techniques were used to maximize cell efficiency with regard to converting chemical energy of the input fuel to electrical energy, while simultaneously minimizing the sensitivity to uncontrollable external influences (noises). The test plan included the same parameters that were varied in the numerical simulations - channel-to-land ratio, channel width, total flow area, and manifold configuration. Noise factors included reformate composition, anode water content, air stoichs, and cell compression, to name a few.

The primary signal and response used for this optimization was a Plug Powerdeveloped algorithm that evaluates peak cell power as a function of fuel flow rate over the anticipated operating range of the system. Cell resistance, phosphoric acid loss, and flow field pressure drop were evaluated as secondary responses.

Testing was conducted using $50-\mathrm{cm}^{2}$ cells, and the results were verified on full-size cells. Empirical results were compared with CFD simulation results and found to be inconsistent. We investigated other factors beyond fluid dynamics that impact cell performance. It should be noted that scale-up of the empirically determined optimized design was not practical because the required geometry results in unreasonable channel depth. The results of the studies of additional parameters will be used in tradeoffs to optimize a scaled-up flow field design within the constraints of plate manufacturing processes.

As discussed previously, the behavior of PBI membranes under a compressive load suggested that the plates in high-temperature stacks must be designed to accommodate the rapid stress relaxation that can occur in these membranes. An existing full-size plate design was modified to prevent overcompressing the membranes. A short stack of four cells was built with a preliminary version of this redesigned plate and operated with no unusual cell degradation for over 650 hours. The stack was operated with reformate containing $27 \%$ hydrogen (dry) and $1 \%$ carbon monoxide (dry), at a temperature of $180^{\circ} \mathrm{C}$, an anode dew point of $55^{\circ} \mathrm{C}$, and a pressure of $1 \mathrm{~atm}$. This design exhibited a constant open circuit voltage over several hundred hours of operation. 
Flow Field Tests. Flow field tests were performed on nine geometries. Anode design was the focus of these tests, since the anode stoich performance is the most critical to the system design. Two anode flow paths and nine channel geometries were tested. Testing accuracy was enhanced by GC measurements of the cell exhaust in order to quantify exact hydrogen utilization.

The benchmark for anode utilization was chosen to be peak efficiency vs. utilization. Efficiency was defined as:

$$
\text { CellEff }=\mathrm{CV} / 1.25 * \mathrm{U}
$$

Where $\mathrm{CV}$ is cell voltage, 1.25 is the ideal voltage (relative to enthalpy), and $\mathrm{U}$ is hydrogen utilization.

Testing showed a significant effect of performance between single pass and double pass plates. As Figure 70 shows, maximum utilization was observed with single pass (1-8a) plates to be on the order of $93 \%$ to $96 \%$ at peak efficiency, while single-pass peaked out at only $83 \%$ to $91 \%$.

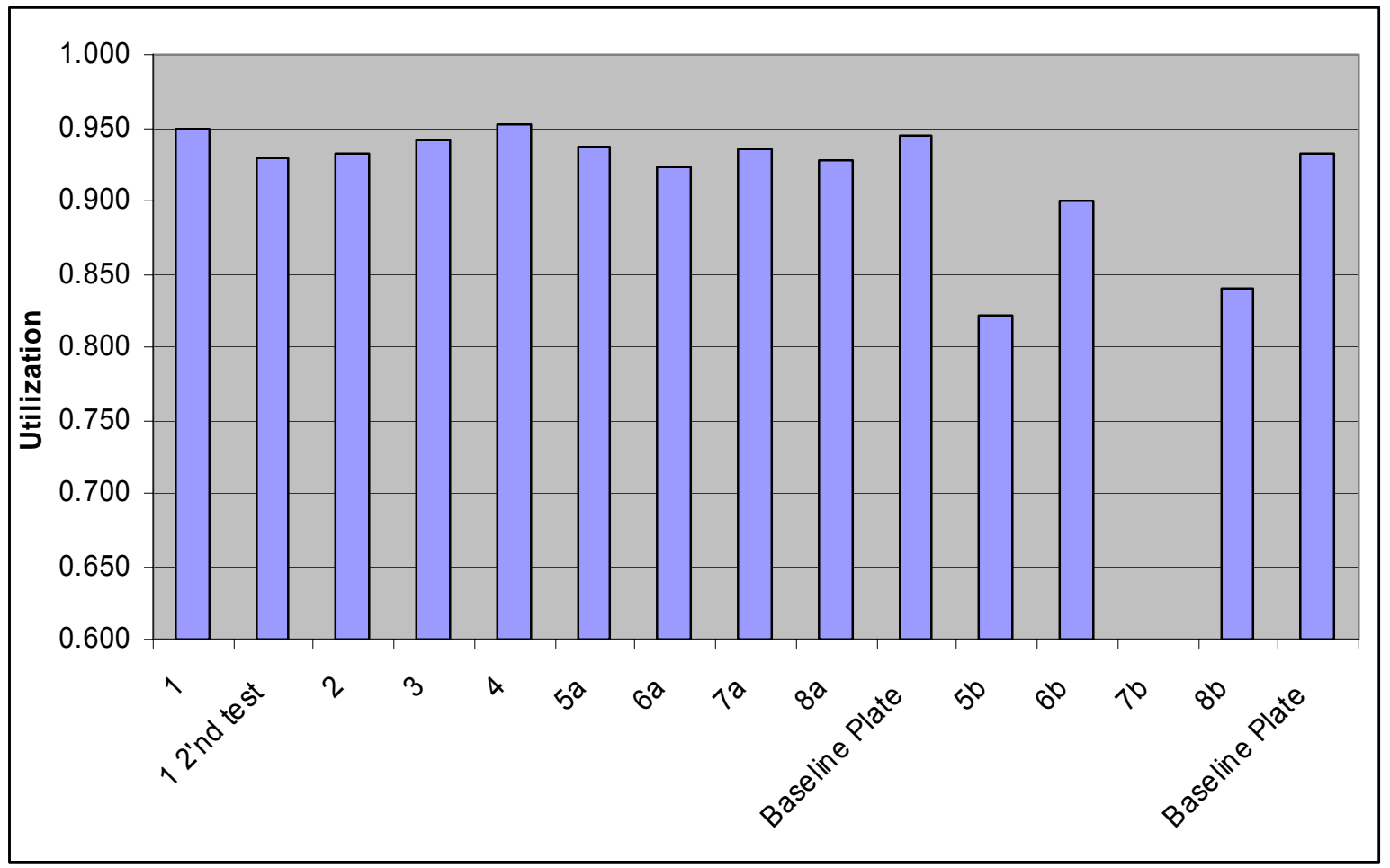

Figure 70: Data for All Cells Plotted in Efficiency vs. H2 Utilization.

Plate Corrosion Test Rig Setup. In the high-temperature cell environment, plate corrosion may be significant. We constructed a corrosion test rig as shown in Figure 71. The standard hydrogen electrode (SHE) was used as a reference electrode, in order to meet the high-temperature requirement. 


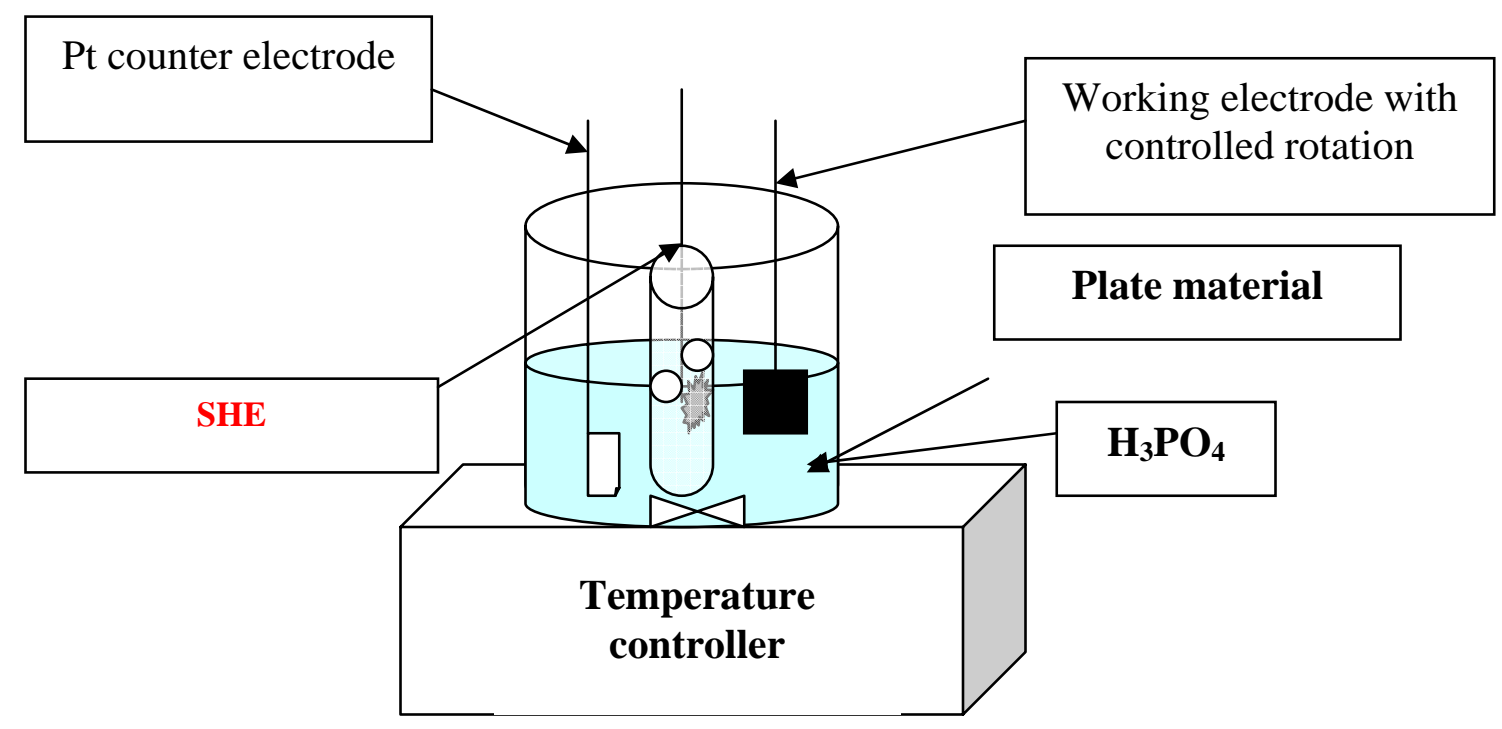

Figure 71: Schematic of the Plate Material Corrosion Test Fixture

Gasket Design. Literature and patent searches were conducted to identify the current state of the art in high-temperature fuel cell stack sealing. The results of the compression testing of the membranes suggested that lower stack assembly compression loads than previously used are appropriate for PBI membranes. Consequently, we investigated sealing methods compatible with low compression.

Gasket design requirements were developed based on stress relaxation, material compatibility, and leakage data obtained on previous high-temperature stacks and stack components. The operating conditions of PBI-based cells - elevated temperatures and the presence of phosphoric acid - made direct transfer of low-temperature sealing mechanisms difficult. 
Sealing and Bonding Material. The goal of this work was to develop materials and methods of application to permanently seal interfaces between coolers as well as between cells in a high temperature phosphoric acid fuel cell operating environment. The decision was made to use the same non-conductive adhesive in all interfaces, designing the plate features such that suitable conductivity is achieved in the cooler interfaces, and using an insulator to keep the cell interfaces non-conductive.

Prototype cells were prepared for testing in operation of a stack. These are single bonded cells which will be inserted into a stack with the majority of cells sealed with traditional gaskets. A process was established for application of the adhesive and assembly of the parts to produce a consistent continuous seal. The development of this process utilized machined anode and cathode plates with a simplified design, bonded together with an MEA between the plates.

The groove design and manufacturing process were finalized. Initial inspection of the adhesive bead before assembly showed a smooth, continuous bead with no visible defects. However, after assembly and curing of the adhesive, a leak check showed loss of pressure in many cases, and no loss in others. This loss of pressure was only observed in cells (with an MEA), and not in the cooler interface. One plate was sanded off and the MEA removed to inspect the cured adhesive bead. Visible voids in the bead were determined to develop during the heat curing process due to inadequate venting. Various venting designs, assembly procedures, and curing protocols were evaluated to understand and control this phenomenon.

Evaluation of the 1-part liquid adhesive continued. Cured samples of the adhesive showed that some element of the adhesive was reacting with phosphoric acid at elevated temperature. Several alternative additives were evaluated for compatibility with acid at $180^{\circ} \mathrm{C}$. Two alternate formulations of adhesive with the alternate additives were received. These cured adhesives were subjected to exposure in acid at $160^{\circ} \mathrm{C}$ and $180^{\circ} \mathrm{C}$. After 24 hours, the samples at $160^{\circ} \mathrm{C}$ were acceptable, but those at $180^{\circ} \mathrm{C}$ showed some discoloration and precipitation in the phosphoric acid when compared with a control sample of acid. Since the current stack is designed to operate at $160^{\circ} \mathrm{C}$, the adhesive was deemed acceptable for prototype builds. Future work should take into consideration how to determine the root cause of the acid discoloration and alternate materials for operation at $180^{\circ} \mathrm{C}$.

A 2-D finite element analysis (FEA) was completed, including compression of the MEA at two different set displacement values. The reaction force of the MEA compression on the separator plates identified the required bond strength of the cured adhesive based on the highest stress point within the cell. The analysis showed the required adhesive bond strength to be lower than the experimental data from previous bonded disk studies. This implies a safety factor in bond strength is offered by this adhesive design.

A detailed finite element analysis was conducted to study the bonded seal design at Entegris. The parameters for the study are described below: 
Input

- ProE solid model: bipolar_adhesive_groove.prt and fea_deformation_only.asm.

Only $1 / 4$ model used for analysis.

- Two analysis types: (1) MEA model included

(2) No MEA model, 80 psi directly applied on the plate

- Material properties:

o Bi-polar plates: $\quad \mathrm{E}=2.3 \mathrm{e}+06 \mathrm{psi}, v=0.3$

o MEA: stress vs. strain curve provided by "Load vs Cell strain - PEMEAS Electrode/GDL-APP-2184(6-10-05)"

o CorrR20u (Load increasing) data is used.

Output

o The maximum displacement of the plate $w /$ MEA is: $8.04 \mathrm{e}-3$ inch.

o The maximum displacement of the plate w/o MEA is: $7.64 \mathrm{e}-1$ inch.

o Reaction force calculated for the $1 / 4$ model is about $600 \mathrm{lbs}$.

$\underline{\text { Notes }}$

o The CorrR20u data (load increasing) was employed because the CorrR20d data (load decreasing) yielded a convergence problem. This may be due to the accuracy of the experimental curve fitting issue.

o For the $2^{\text {nd }}$ analysis, which has no MEA model, the relation between pressure and the maximum displacement calculated is linear. Therefore, if the pressure increases from $80 \mathrm{psi}$ to $160 \mathrm{psi}$, the maximum displacement increases from 0.764 " to 1.528 ".

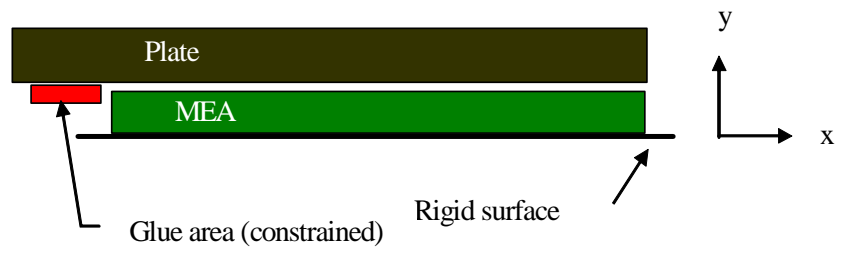

(1) The half model is used for analysis. The original MEA thickness is assumed to be 0.0359 ', so the MEA thickness modeled is 0.01795 ".

(2) The initial gap between plate and MEA is 0.0005 inch.

(3) The rigid surface is translated by 0.0035 " in the positive y direction. Therefore, the MEA is compressed by $0.0030 "$.

Figure 72: Plate FEA Methodology 
Using this analysis and model the following results were obtained:

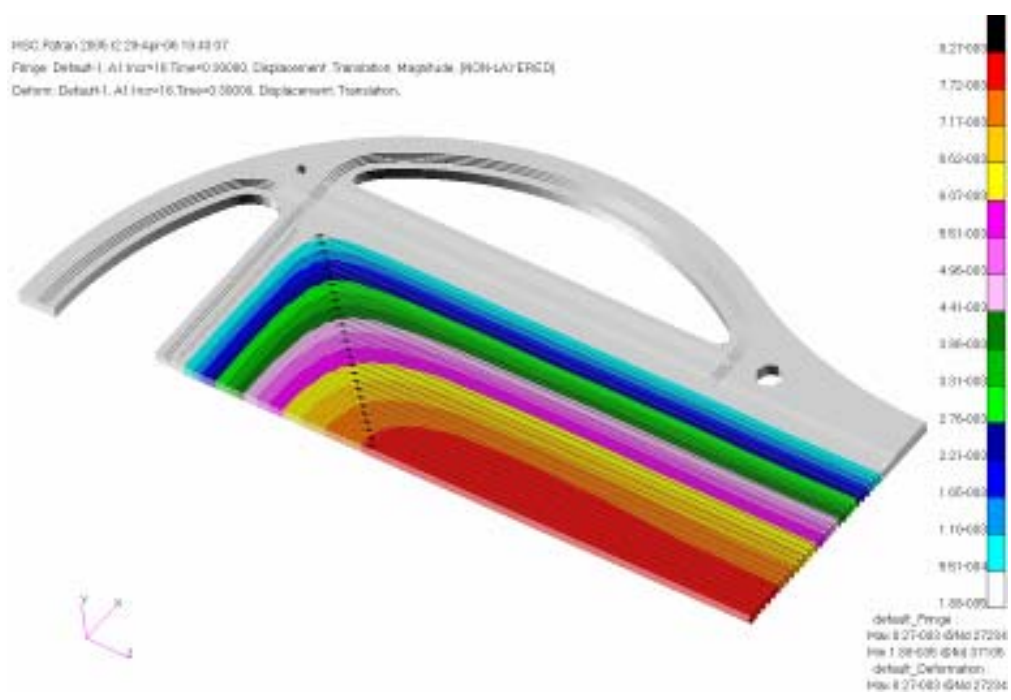

Figure 73: FEA Output - Deflection

Because of the size of the plate, potential deflection in the Z-direction of the center of the plate was found to be significant. Bonding the edge helps this previously unknown issue especially with the cooler plates; where upon further investigation it was found that the hydraulic pressure from the oil coolant deflects the plates.

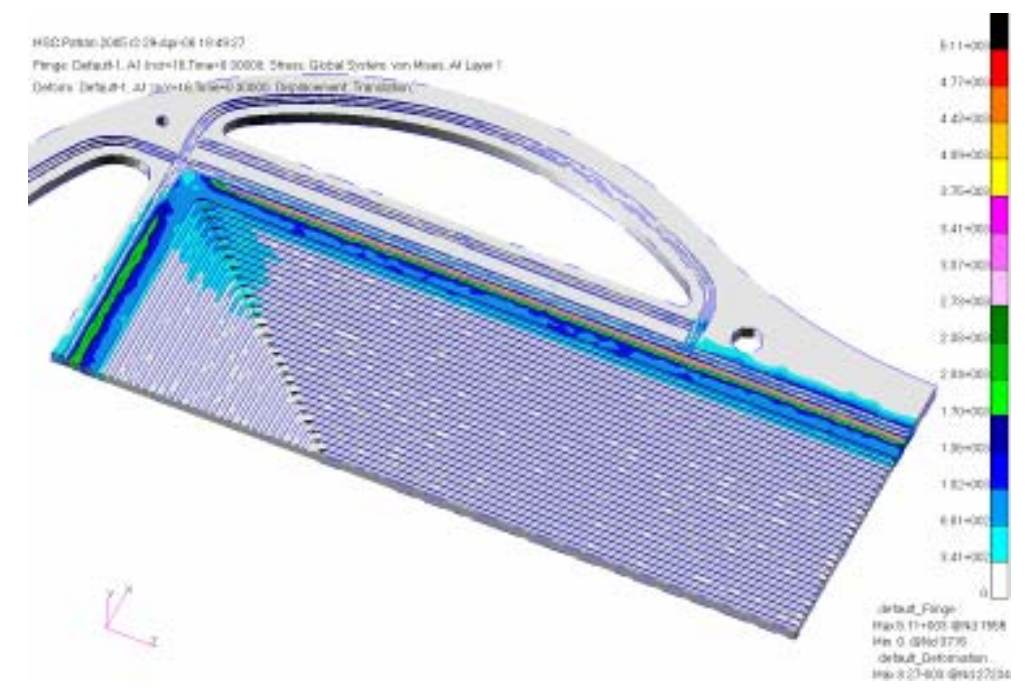

Figure 74: FEA Output - Edge Stress

By rigidly fixing the edge, thermal expansion and contraction stresses need to be taken into account in the plate and bond design. 
In summary, the FEA determined bonding a plate this size is possible but requires careful consideration to the design of the plate geometry and bond. It also uncovered a potential source of MEA over compression in the current design.

Steam Generation. It was found due to the high moisture content in the MEA in conjunction with the cure temp and ramp time that steam was being generated and causing the adhesive to burp leaving gaps or leak paths, which are unacceptable. A short term solution was found. First baking the MEA for a period of time to evaporate a portion of the water in conjunction with slowly ramping the plates over a longer period of time greatly reduced the amount of steam building up, in turn yielding acceptable single cells tested at Entegris. This baking operation has the drawback of forcing water and acid out of the MEA due to evaporative mechanisms. The rate of loss, and its impact on performance was not investigated at this time.

Plate Assembly Fixture Adjustment. Upon bonding and curing plates machined from SGL slabs, it was noted a large enough difference with regards to the coefficient of thermal expansion existed between the aluminum fixture and the plates to cause cracking. The fixture was updated to allow the pins to float along with giving the pins more clearance in the hole itself. Recent bonding trials showed no cracks in the plates

Bridge Plate Attachment. A leak path occurred if the bridge plates were not bonded separately form the entire plate. A separate operation was set up to apply adhesive in and around the bridge plate area to eliminate the leak path.

MEA Shorting. Upon bonding the first test cells an electrical short was observed between the two plates. It was assumed that the shorting was caused by either a breakdown of the Viton insulator or mechanical contact between the plates as a result of the clamping and curing process. A series of tests were run, sectioning the bonded cell and looking for regions that exhibited the short. It was found that all sections did. Attention was then turned towards the MEA itself. A test was devised to test dielectric properties of the MEA using machined plate blanks that were sized to the GDL and provided no potential for edge shorting. This test showed shorting prior to the bonding. The results could not be duplicated at Plug Power so there is still some understanding of the results that needs to be explored.

Delivery of Bonded Cells. As mentioned above, the first large format $(440 \mathrm{~cm} 2)$ bonded cell was sacrificed to explore the cell shorting issues. After fixturing improvements a second cell was bonded and delivered to Plug Power intact. This cell, in addition to three additional cells that will be supplied, will for the basis of our durability testing.

\section{Compression Failure Modes}

LSL MEAN USL 


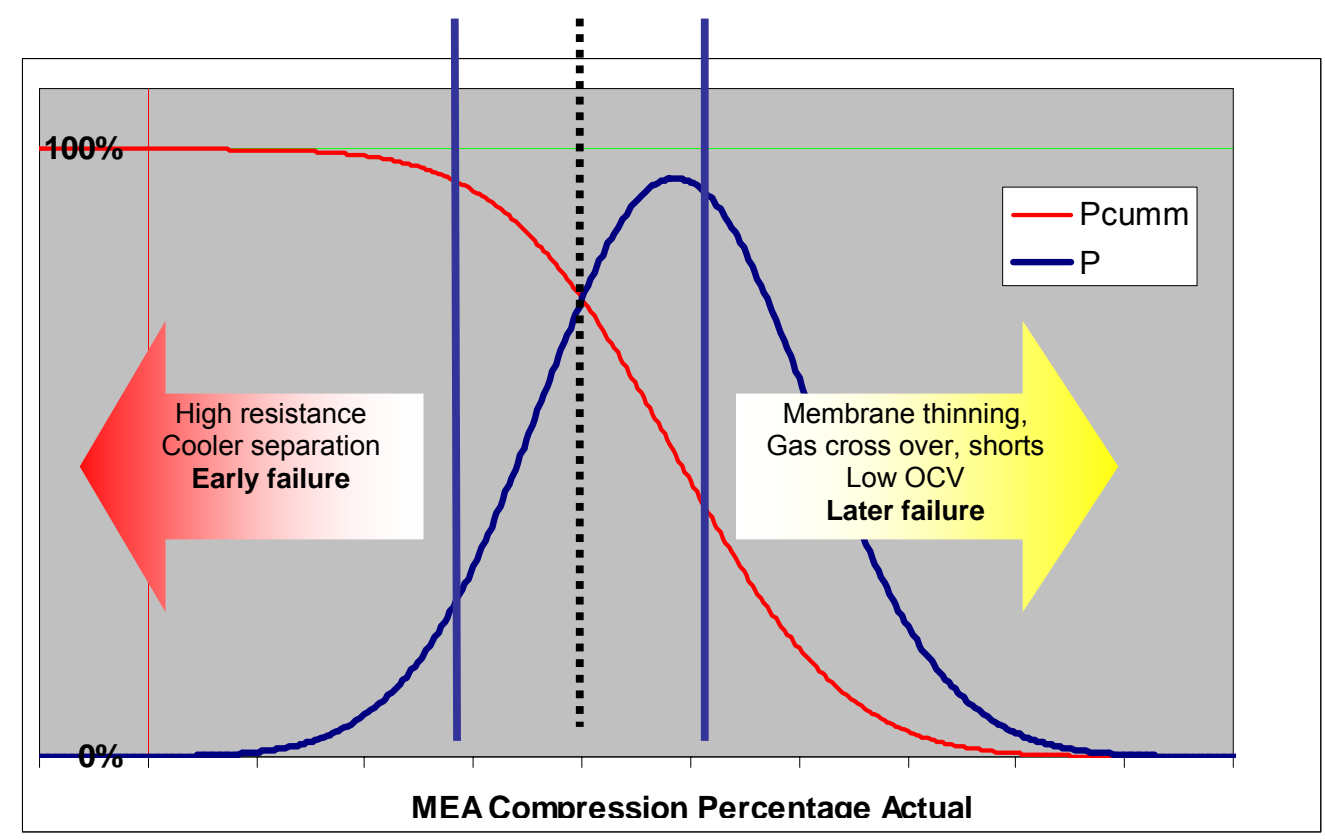

Figure 75: Schematic of the Plate Material Corrosion Test Fixture

Because of the stress relaxation characteristics of the PBI MEA, BASF provides compression guidance to ensure good electrical contact between plates but prevent over compression. The FEA and experimental observations led Plug Power to reanalyze its tolerance stack up with regard to pocket depth and plate compression.

Upon original design of the current plate, a tolerance analysis was conducted on the as specified geometric parameters of both the plate and the MEA. Now, a full as found analysis was conducted with surprising results. The above distribution curve shows the as found tolerance stack up vs. the upper and lower specification limits from BASF. The total tolerance has a higher mean and wider variation than the MEA can withstand.

Further investigation found that while the mean can be shifted by changing certain parameters, the variation cannot be significantly decreased using standard manufacturing methods. Shifting the mean without decreasing the variation puts more cells at risk of early failure modes.

This discovery could provide insight into observations made on the performance of the first short stack ( 16 cell module) using early BASF MEAs.

Four, single-bonded cells have been produced by Entegris Corporation using a proprietary 1- part heat curing adhesive bismaleimide or BMI. The adhesive was dispensed on custom machined plates with an adhesive groove designed for optimal encapsulation of the MEA subframe edge. The assembled cells were fixtured and oven cured. 

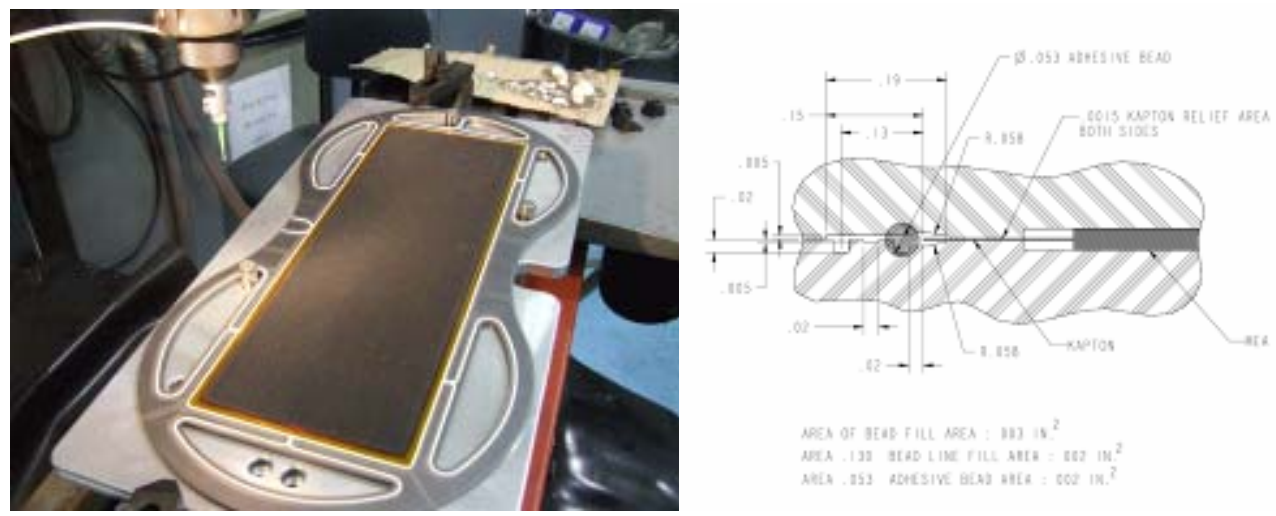

Figure 76: Bonded Plate Hardware and Schematic

The completed cells were assembled into a four-cell module, leak-checked, and prepared for beginning of life characterization.

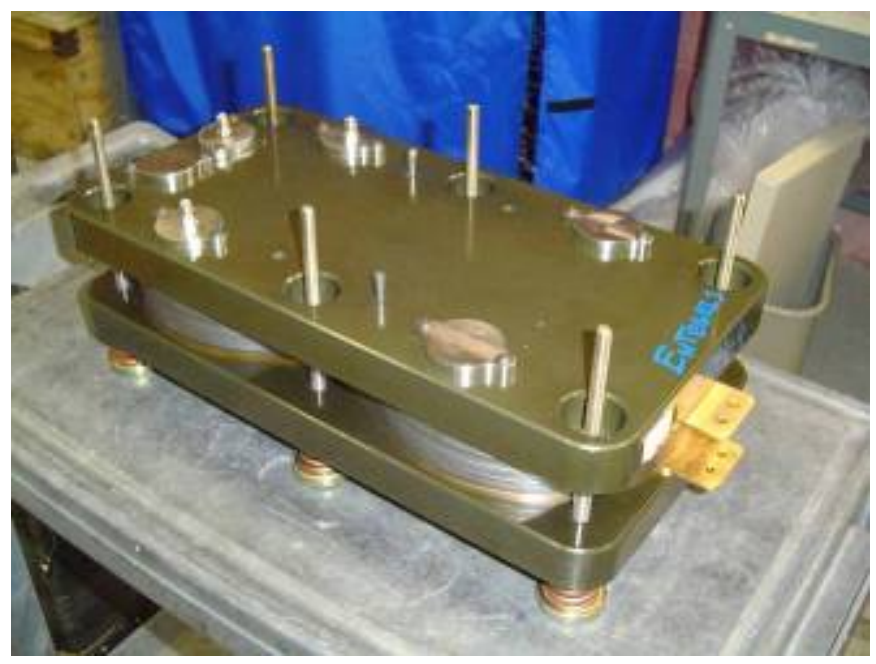

Figure 77: Bonded Plate Module

\section{Task 11: Electrode Development and Performance Improvement}

\section{Electrode Fabrication and Structure Optimization}

Previous to this program, a half-cell rig was obtained to measure the performance of a cathode relative to a reference electrode (Figure 78). The goal of the work on the halfcell rig is to create a rapid low-cost test bed for new electrode evaluation. 


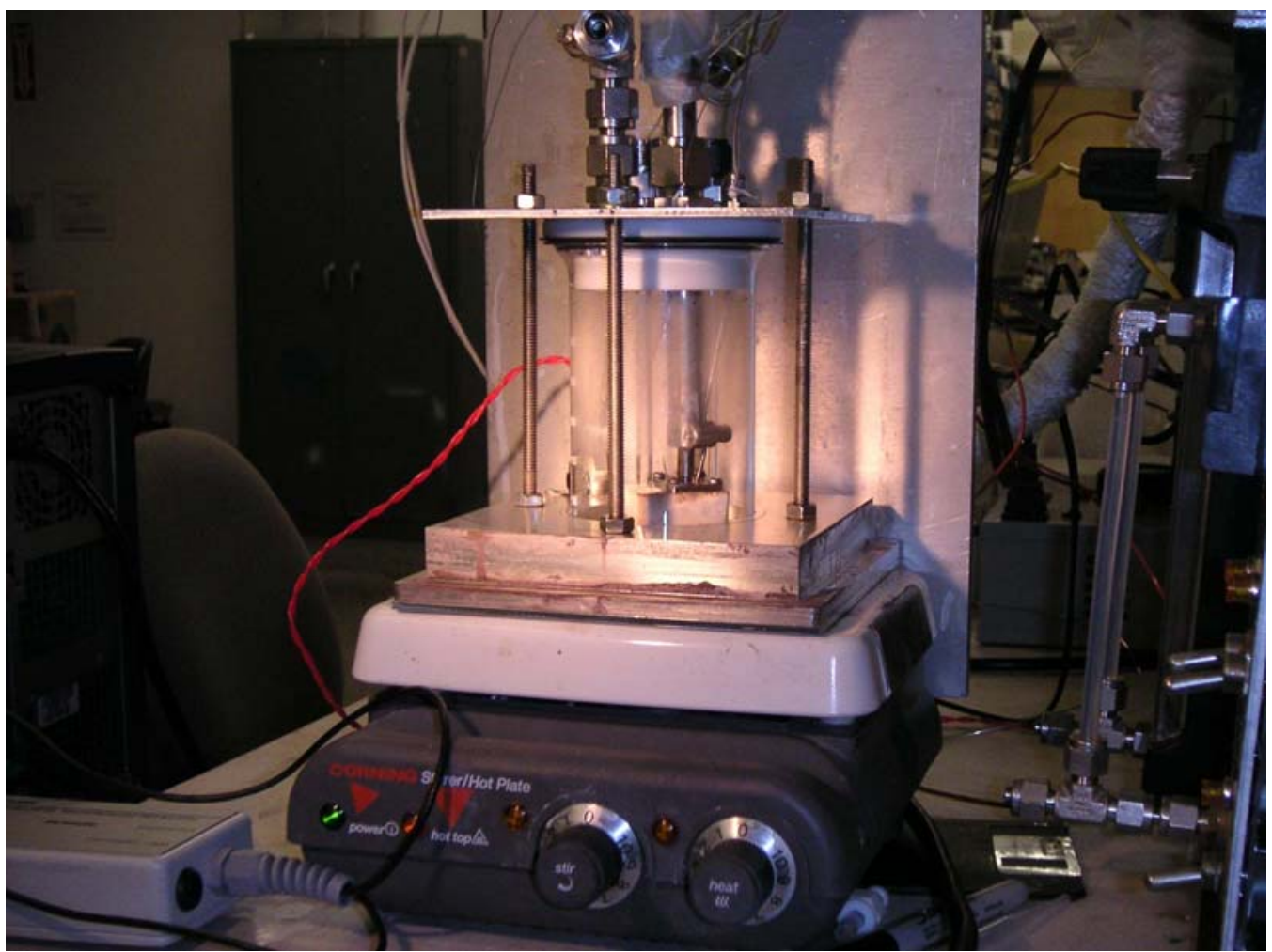

Figure 78: Half-cell Test Rig Used to Quantify the Performance of New Electrodes

A spray process for coating electrodes that produces a uniform coating with good adhesion properties was developed and was used as the baseline for work during the program. Variations in surfactant concentration were made to determine the effect on coating and particle size.

The spraying method that was developed involves making a series of thin coats of catalyst with an air sprayer, drying each layer with hot air before apply the next coating. These coatings have been found to be adherent and uniform. A comparison of an electrode formed by spraying and an electrode formed by rolling is provided in Figure 79. As the process was being developed, the size of the catalyst particles was varied by varying the surfactant concentration. The surfactant binds to the surface of the carbon support particles, preventing them from agglomerating. Agglomerate size is therefore reduced as surfactant concentration is increased.

(A)

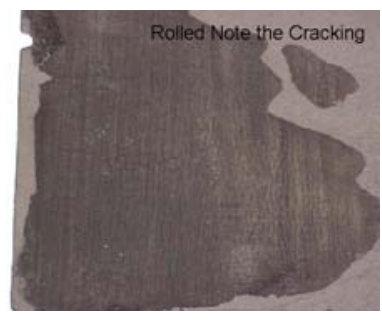

(B)

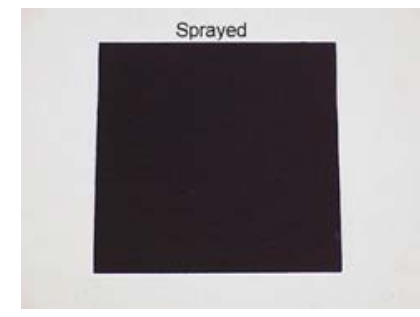


Figure 79: Comparison of Electrode Preparation techniques. (A) Rolled Using a Meyer Rod. (B) Sprayed as Described in the Text. Note the Cracking in the Rolled Electrode and the Uniformity of the Sprayed Electrode.

Once the process was developed, four $50-\mathrm{cm}^{2}$ MEAs were prepared using Celtec-P PBI membrane (the current standard material). The first MEA was to test an electrode coated with the spraying method. The purpose of the next two MEAs is to study the effect of leaching the surfactant before sintering. A high level of surfactant was used in the catalyst ink; one electrode was subjected to leaching and the second was not before testing. The purpose of the fourth electrode is to test a low surfactant level to investigate the performance sensitivity to surfactant concentration.

The performance of the first electrode made by a spraying process was the best of any electrode built under this program. Cell voltage of 0.610 volts was obtained at 200 $\mathrm{ma} / \mathrm{cm}^{2}$ at $160^{\circ} \mathrm{C}$ on hydrogen; catalyst loading was $0.35 \mathrm{mg} / \mathrm{cm}^{2}$. The polarization curve is shown in Figure 80 . The Tafel slope of 95 millivolts per decade on this cell was consistent with historical values. The oxygen gain was lower than historical values of 80 millivolts and slightly greater

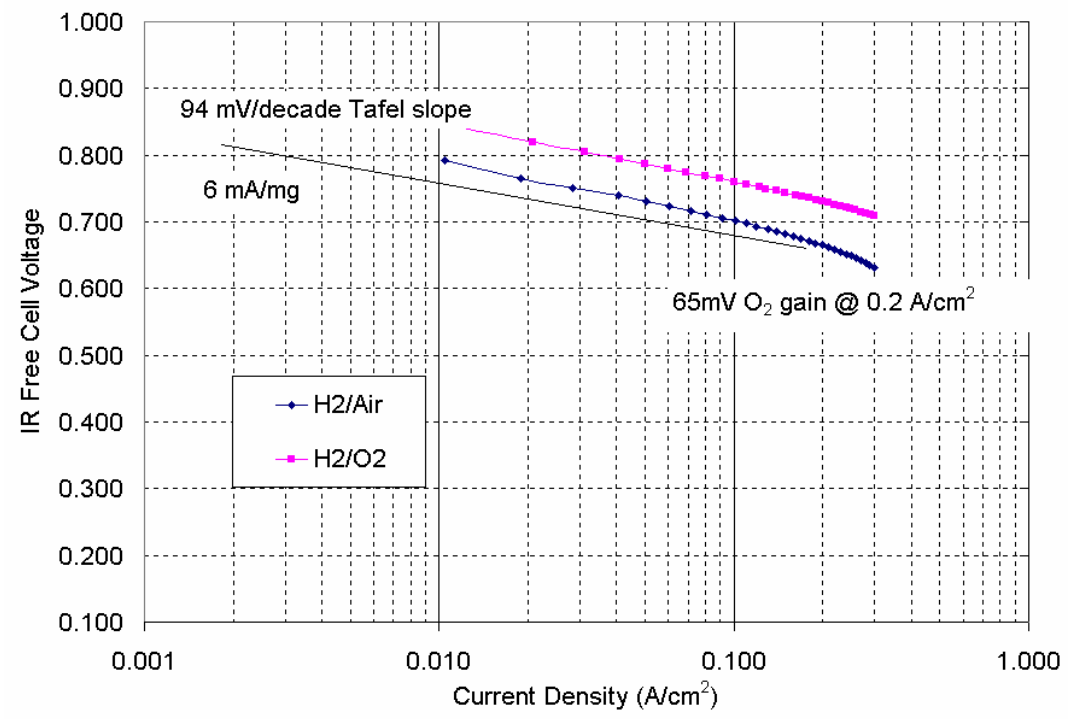

Figure 80: Performance of Cell 2652. Electrodes were Made Using a Spraying Process. Catalyst Loading was $0.35 \mathrm{mg} / \mathrm{cm}^{2}$

than what would be expected with no diffusion loss at 65 millivolts. The electrode was not flooded and did not exhibit a high diffusion loss. The utilization of catalyst was 6 $\mathrm{ma} / \mathrm{mg}$. Utilization of $28 \mathrm{ma} / \mathrm{mg}$ is possible based reference data. It would appear from these data that only a small percentage of the catalyst is in contact with electrolyte. The goal of the program moving forward will be to raise this utilization while maintaining low diffusion resistance. 
Electrode structures were characterized using tools available at Albany NanoTech (ANT), such as high resolution scanning electron microscopy (SEM), energy dispersive X-rays (EDX), X-ray mapping, focused ion beam (FIB), and X-ray diffraction (XRD). These techniques allowed us to:

a. Understand the surface and subsurface morphology of catalyst layers, i.e., porosity distribution, connectivity, Teflon distribution, agglomeration of any phase, microstructural inhomogeneities, and platinum particle size and orientation;

b. Correlate sample processing with microstructure and performance.

We examined electrodes fabricated with different process conditions and compositions, including the effect of surfactant concentrations in the catalyst "ink," the presence or absence of PTFE in the electrode, the effect of sintering, and the effect of stirring rate. We also looked at the microstructures of standard commercial catalysts and compared them with those prepared in-house.

Some of the major findings include:

1. XRD can be used to estimate Pt particle size. However, there are limits; due to the presence of a weak peak of $\mathrm{Pt}(111)$ in the samples with $10 \mathrm{wt} \% \mathrm{Pt}$, it is difficult to use the XRD tool effectively for conclusively determining Pt particle size. We are investigating other techniques such as TEM for this purpose.

2. FIB can be used effectively to relate porosity and pore connectivity to process conditions and compositions.

3. X-ray elemental mapping helps in understanding $\mathrm{Pt}$ and Teflon distribution. However, other techniques such as X-ray photoelectron spectroscopy (XPS) may be needed to quantify Teflon and Pt distribution.

Sample Processing. The second task, deposition of nanoscale Pt catalyst structures on suitable substrates identified with Plug Power, consisted of the following activities:

1. Deposition and pre/post deposition treatment parameters will be varied to adjust particle size, uniformity, and mass distribution of catalyst structures.

2. Characterization of deposited catalyst structures with respect to particle size, aspect ratio, and degree of crystalline order.

3. Delivery of selected catalyst structures to Plug Power for electrochemical evaluation.

Given the relatively long period required to develop typical chemical vapor deposition (CVD) processes compared to the much shorter period required to develop typical sputter deposition (SD) processes, the deposition technique selected to begin this program was SD. While preliminary catalyst structures are prepared via SD, a suitable CVD processes will be sought in the future.

Two substrates were selected within the typical high temperature, PEM-based, fuel cell system as suitable candidates for deposition of nanoscale Pt particles. Both substrates 
were GDLs; one GDL was untreated Toray paper, while the other GDL was Toray paper treated with a microlayer of carbon black and PTFE particles.

Plasma Treatment and Pt SD. Pt SDs were completed using an Anatech Hummer 10.2 sputter-coating tool (Figure 81). A modified sample stage was used to support the GDL substrates.
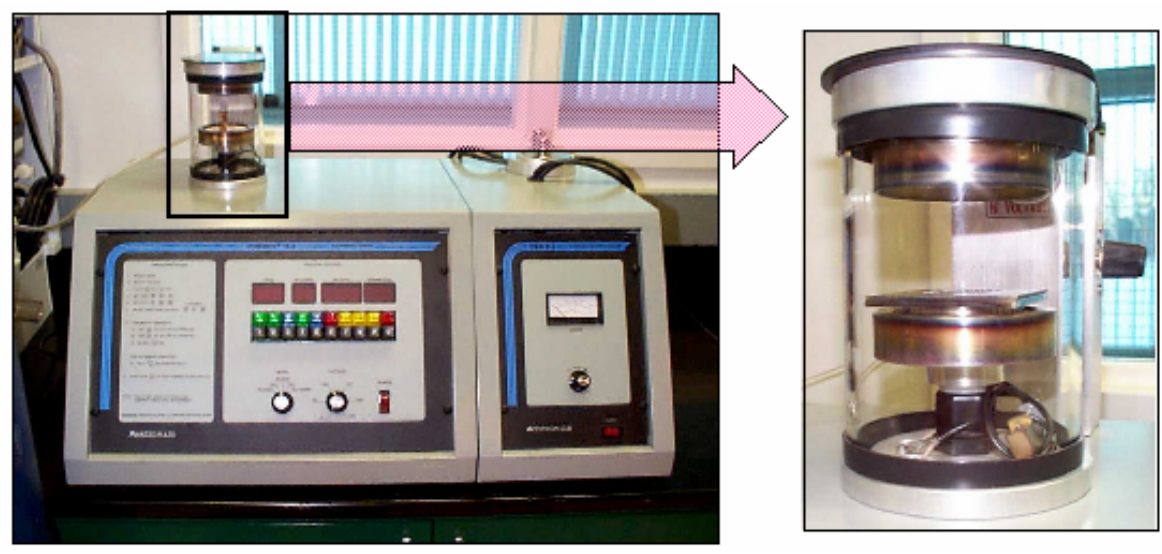

Figure 81: Anatech Hummer 10.2 Tool Used for SD

An aluminum target was used for $\mathrm{AC}$ and $\mathrm{DC}$ plasma modifications, while a $\mathrm{Pt}$ (Anatech) target was used for SDs.

The distance between the target and the sample stage was maintained at $40 \mathrm{~mm}$. Sequential in situ processing was utilized where possible, although a single target had to be used for the entire treatment sequence. A potential of $1.8 \mathrm{kV}$ and a current of 8 $\mathrm{mA}$ was maintained to control the $\mathrm{Pt}$ deposition rate. $\mathrm{A} \mathrm{SiO}{ }_{2}$ sample was $\mathrm{SD}$ in situ with each GDL. The resultant $\mathrm{Pt} / \mathrm{SiO}_{2}$ stack was subjected to cross-sectional view SEM imaging to verify the SD film thickness. A top-view SEM image was also acquired to estimate the surface coverage of the SD film (typically 65\%). These two values were used along with bulk density $(\mathrm{Pt}=21.4 \mathrm{~g} / \mathrm{ml})$ to calculate $\mathrm{Pt}$ loading on each catalyst structure. Continuous Pt SD was limited to durations less than 20 minutes.

Catalyst Structures with Nanoscale Pt Particles. Six types of catalyst structures were prepared via sputter deposition. Three of these catalyst structures were on Grey GDL with SD Pt for varying times, while three more of these catalyst structures were prepared on Black GDL with SD Pt. Details of these SD catalyst structures are summarized in Table 28.

\begin{tabular}{|c|c|c|c|}
\hline Substrate & SD Duration & SD Thickness & \multicolumn{2}{|c|}{ Pt Loading ** } \\
\hline Black GDL & A minutes & $\sim 20 \mathrm{~nm}$ & $27 \mathrm{~g} / \mathrm{cm}^{2}$ \\
\hline Black GDL & B minutes & $140 \mathrm{~nm}$ & $190 \mathrm{~g} / \mathrm{cm}^{2}$ \\
\hline Black GDL & C minutes & $230 \mathrm{~nm}$ & $315 \mathrm{~g} / \mathrm{cm}^{2}$ \\
\hline Grey GDL & A minutes & $\sim 20 \mathrm{~nm}$ & $27 \mathrm{~g} / \mathrm{cm}^{2}$ \\
\hline
\end{tabular}




\begin{tabular}{|c|c|c|r|}
\hline Grey GDL & B minutes & $95 \mathrm{~nm}$ & $130 \mathrm{~g} / \mathrm{cm}^{2}$ \\
\hline Grey GDL & C minutes & $230 \mathrm{~nm}$ & $315 \mathrm{~g} / \mathrm{cm}^{2}$ \\
\hline
\end{tabular}

${ }^{*} \mathrm{SD}$ thickness determined from in situ SD $\mathrm{Si} / \mathrm{SiO}_{2} / \mathrm{Pt}$ samples.

${ }^{* *}$ Pt loading was determined from SD thickness \& typical surface coverage of $\sim 65 \%$.

\section{Table 28: Summary of SD Catalyst Structures}

Characterization via Scanning Electron Microscopy (SEM). Despite the reproducible nature of the SD Pt films, a SiO2 substrate was in situ deposited with most catalyst structures. Pt loadings were then verified via cross-sectional and top view SEM images (Figure 8). Pt loadings below $\sim 50 \mu \mathrm{g} / \mathrm{cm} 2$ could not be directly measured or verified very accurately; only the combined thickness of several SD Pt films/layers could be used for accurate measurements or verifications due to a thickness limitation of approximately 5-15 nm for accurate SEM measurements.

Although the short deposition appears to yield a continuous film, the longer depositions yield a columnar nanostructure expected for thicker Pt films with these SD conditions (substrate temperature $\sim 22{ }^{\circ} \mathrm{C}$, pressure $\sim 65$ mtorr).

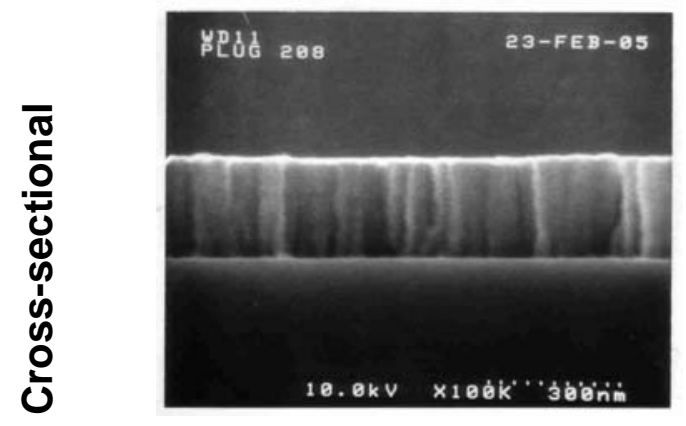

C minutes Pt

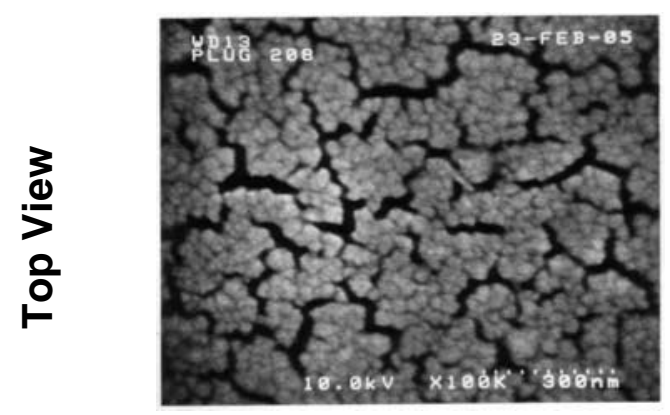

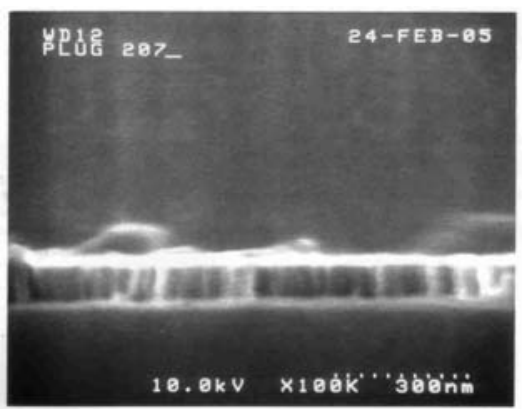

B minutes Pt

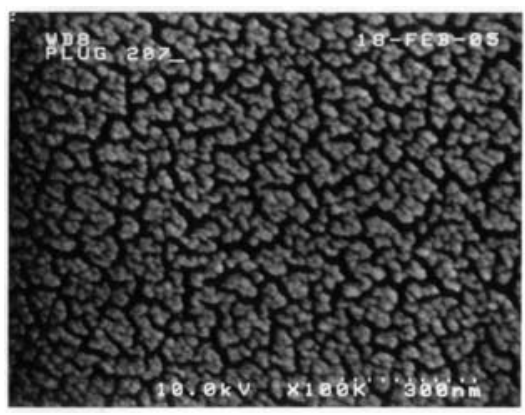

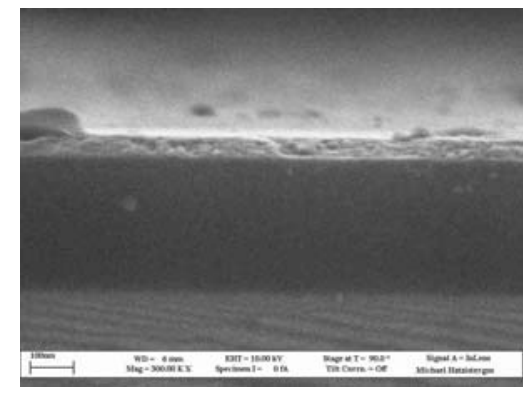

A minutes Pt

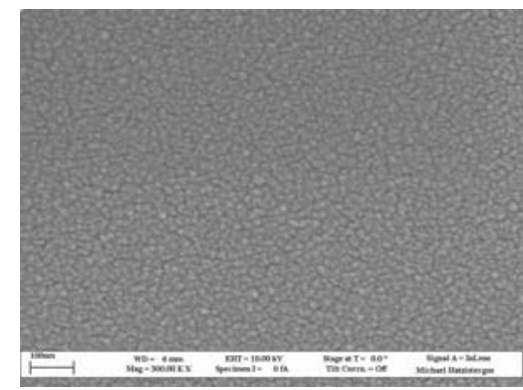

Figure 82: SEM Images of SD Pt on $\mathrm{Si} \mathrm{SiO}_{2}$ Substrates From Preparation of Grey GDL Catalyst Structures 
Characterization via Electrochemical Testing. Set out in Figure 83 are potential versus current plots from electrical testing of catalyst structure with shorter time of SD Pt on Black GDL and and longer time of SD Pt on Black GDL that were obtained by Plug Power. Both plots suggest that SD Pt could be acting as a barrier to diffusion of reactants to active catalysis sites.
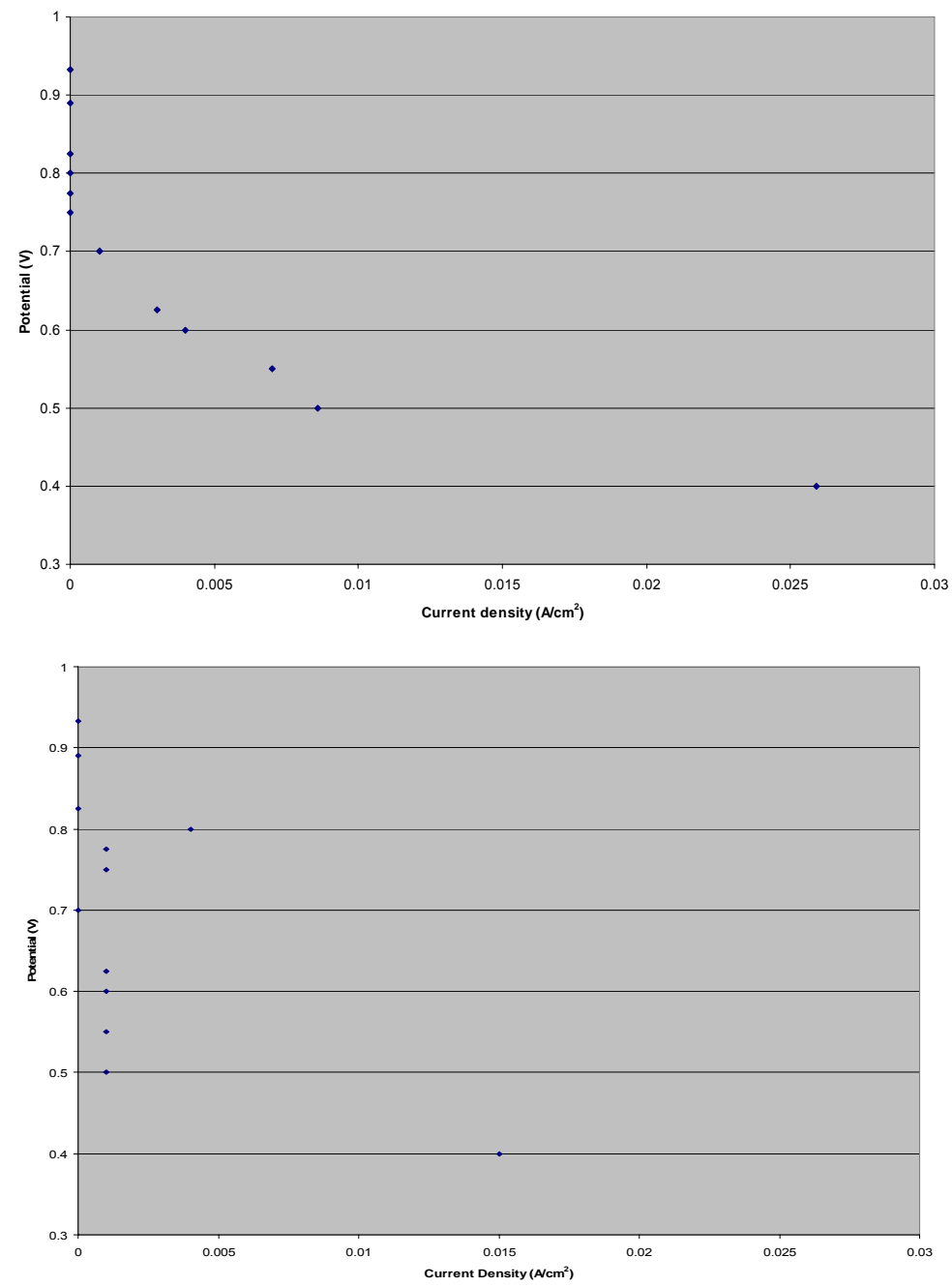

Figure 83: Potential versus Current Plots from Electrical Testing of Catalyst Structure with Shorter Time of SD Pt on Black GDL (top) and Longer Time of SD Pt on Black GDL (bottom) 
Conclusions of Electrode Development. Though performance was well below that of typical baseline catalyst structures for the nanoscale Pt catalyst structures studied to date, this is not unexpected given the limited number of expected "quadruple points" for active catalysis in these first pass catalyst structures.

SD Treatments: SDs on $\mathrm{SiO} 2$ in situ with each GDL was completed using an Anatech Hummer 10.2 sputter-coating tool with a Pt target. SD film thickness and surface coverage (typically $\sim 65 \%$ ), determined from SEM, were used with bulk density ( $\mathrm{Pt}=$ $21.4 \mathrm{~g} / \mathrm{ml}$ ) to estimate Pt loading.

Simple Catalyst Structures: Twelve simple catalyst structures were prepared via SD for electrochemical testing this quarter, six were on Grey GDL and another six on Black GDL with SD Pt for $1,2.5,5,10,37$, and 80 minutes.

Spray Treatment: Spray treatments (ST) were completed on GDLs using a PaascheH10919 Airbrush with a compressed dried air (CDA) supply at $\sim 30$ psig and $\sim 25 \mathrm{~cm}$ spraying distance.

Determination of Catalyst Loading: An average Pt SD rate of $\sim 3.9 \mu \mathrm{g} / \mathrm{cm}^{2} / \mathrm{min}$ was verified with loadings of SD Pt, which is consistent with the SD rate determined for earlier substrates suggesting the Pt SD process set out in experimental details is rather robust.

Spray Treatments of PTFE, CB, and PTFE\&CB Thin Films: PTFE, CB, and PTFE\&CB solutions were sprayed at a supply pressure of 30 psig to obtain reproducible, uniformly distributed STs. Dilution of the above solutions with di-ionized water and methanol, led to more discontinuous films and poorer surface coverage.

More uniform STs were obtained with a large excess ( 5 fold) of surfactant in CB solution which led to development of processes to remove the surfactant after ST.

Stacked Catalyst Structures: Stacked Catalyst Structures were prepared at Albany Nanotech using spray treatment (ST) and sputter deposition (SD). Two sets of substrates each with three replicates were prepared via ST and SD for electrochemical testing using methanol as the solvent for spray deposition as shown in table 2 . The $\mathrm{Pt}$ loading on the stacked substrates was $\sim 1.9 \mu \mathrm{g} / \mathrm{cm}^{2}$, while the Pt loading on the simple substrates was $\sim 7.0 \mu \mathrm{g} / \mathrm{cm}^{2}$. Three other sets of substrates each with two replicates were prepared via ST and SD for electrochemical testing using methanol as the solvent for spray deposition. The Pt loading on all these stacked substrates was $\sim 1.9 \mu \mathrm{g} / \mathrm{cm}^{2}$. 


\begin{tabular}{|c|c|c|c|c|}
\hline $\begin{array}{c}\text { Substrat } \\
\text { e }\end{array}$ & $\begin{array}{c}\text { Solve } \\
\text { nt }\end{array}$ & $\begin{array}{l}\text { Replicat } \\
\text { e }\end{array}$ & Loading & Stacked Structure \\
\hline Woven & $\begin{array}{c}\text { Metha } \\
\text { nol }\end{array}$ & $3 x$ & $\begin{array}{c}\sim 1.9 \\
\mu \mathrm{g} / \mathrm{cm}^{2}\end{array}$ & $\begin{array}{l}\text { GDL/PTFE ST/PTFE\&CB ST/Pt } \\
\text { SD/PTFE\&CB ST }\end{array}$ \\
\hline Woven & $\mathrm{N} / \mathrm{A}$ & $3 x$ & $\begin{array}{c}\sim 7.0 \\
\mu \mathrm{g} / \mathrm{cm}^{2}\end{array}$ & GDL/Pt SD \\
\hline Woven & $\begin{array}{c}\text { Metha } \\
\text { nol }\end{array}$ & $2 x$ & $\begin{array}{c}\sim 1.9 \\
\mu \mathrm{g} / \mathrm{cm}^{2}\end{array}$ & GDL/PTFE\&CB ST/Pt SD/PTFE\&CB ST \\
\hline Woven & $\begin{array}{c}\text { Metha } \\
\text { nol }\end{array}$ & $2 x$ & $\begin{array}{c}\sim 1.9 \\
\mu \mathrm{g} / \mathrm{cm}^{2}\end{array}$ & $\begin{array}{c}\text { GDL/PTFE\&CB ST/Pt SD/PTFE\&CB } \\
\text { ST/PTFE ST }\end{array}$ \\
\hline Woven & $\begin{array}{l}\text { Metha } \\
\text { nol }\end{array}$ & $2 x$ & $\begin{array}{c}\sim 1.9 \\
\mu \mathrm{g} / \mathrm{cm}^{2}\end{array}$ & $\begin{array}{c}\text { GDL/PTFE\&CB ST/PTFE ST/Pt } \\
\text { SD/PTFE\&CB ST }\end{array}$ \\
\hline
\end{tabular}

Table 29: Stacked Catalyst Structures

The resultant stacked structures were provided to Plug Power for electrochemical testing. Reproducible electrochemical testing results have been verified for the first two sets of samples.

Electrochemical testing of two stacked structures on woven GDL has provided encouraging performance metrics. However, the replicates of these stacked structures have not yet been subjected to electrochemical testing to verify these results. The preliminary performance of two of these stacked nanoscale Pt catalyst structures on Woven GDL exceeded the performance of typical baseline structures on woven GDL on a Pt weight basis. Findings suggest that nanoscale Pt catalyst structures may contain a relatively elevated number of "quadruple points" for active catalysis. Further research to both characterize the "quadruple points" present in this structure as well as to optimize the production of this type of structure via nanoscale processing techniques, once the preliminary electrochemical testing is verified.

Ex-situ GDL resistance measurements have been developed and now resistances can be determined within a testing package within a press. Scanning electron microscopy was used to assess PTFE distribution and agglomeration within the GDL structure. It was found that the PTFE distribution and location were very much dependent on the source of the paper. It was also determined that the PTFE was agglomerated. Techniques have been applied to address this issue. With the results of the current testing, it is anticipated that a baseline GDL will be in place shortly.

Preliminary testing on the on the electrode have indicated excellent OCV's, good low current density voltages, but due to the higher resistances, poor mid to high current performance. Initial attempts with one paper led had significant concentration and/or diffusion losses. 
In order to minimize the diffusion losses in PBI oxygen reduction electrodes, there are four paths which were explored. The activities focused on determining the conditions necessary to achieve a mechanical bond between the membrane and GDL components.

All work on this task was stopped as a result in DOE funding cuts from 1Q06.

\section{Electrode Modeling}

Plug Power developed a performance model for electrodes used in high temperature MEAs. The purpose of this modeling effort is to model system behavior, test our understanding, provide a status of where we are with electrode performance, and, finally, provide ideas on what is possible and a roadmap of how to get there. The modeling strategy was:

1. Calculate cathode polarization - Utilize available kinetic data, especially from the PAFC industry and at $190^{\circ} \mathrm{C}$, input catalyst layer properties and input reactant constituents and catalyst utilization.

2. Assume anode polarization using literature and Plug Power data.

3. Assume an IR loss based on Plug Power data.

4. Ignore the mass transport region of the polarization curve.

5. Estimate other losses based on state-of-the-art PAFC performance and Plug Power data.

6. Shift the model results to the desired operating temperature based on observed $1 \mathrm{mV} /{ }^{\circ} \mathrm{C}$ data.

A sample view of the model spreadsheet is provided in Figure 84.

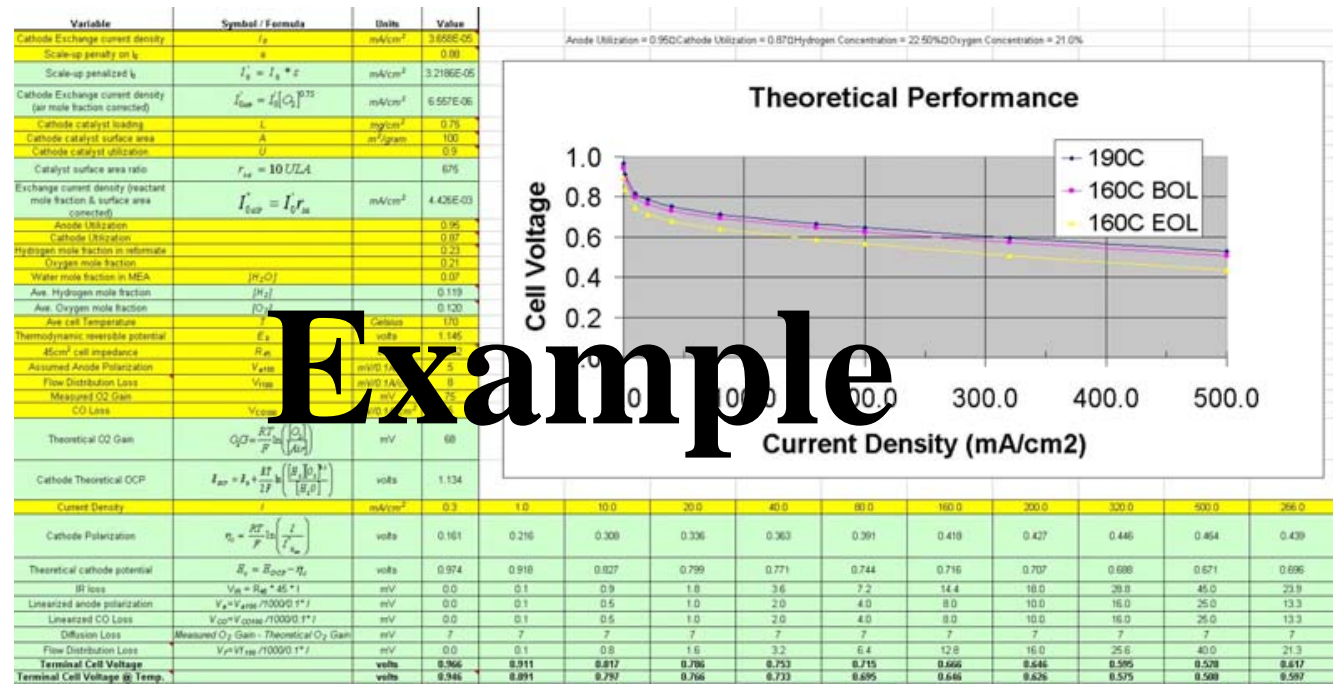


Figure 84: Cell Performance Model

The model has been validated against measured cell data. An example of this comparison is shown in Figure 85. Model assumptions, cell data, and operating conditions for the results in Figure 85 are provided in Table 30. The validation studies such as Figure 85 show excellent agreement between predicted and actual data. There is a significant difference in the open circuit voltage in Figure 85; this is attributable to gas crossover and electrical shorting experience with the test cell.

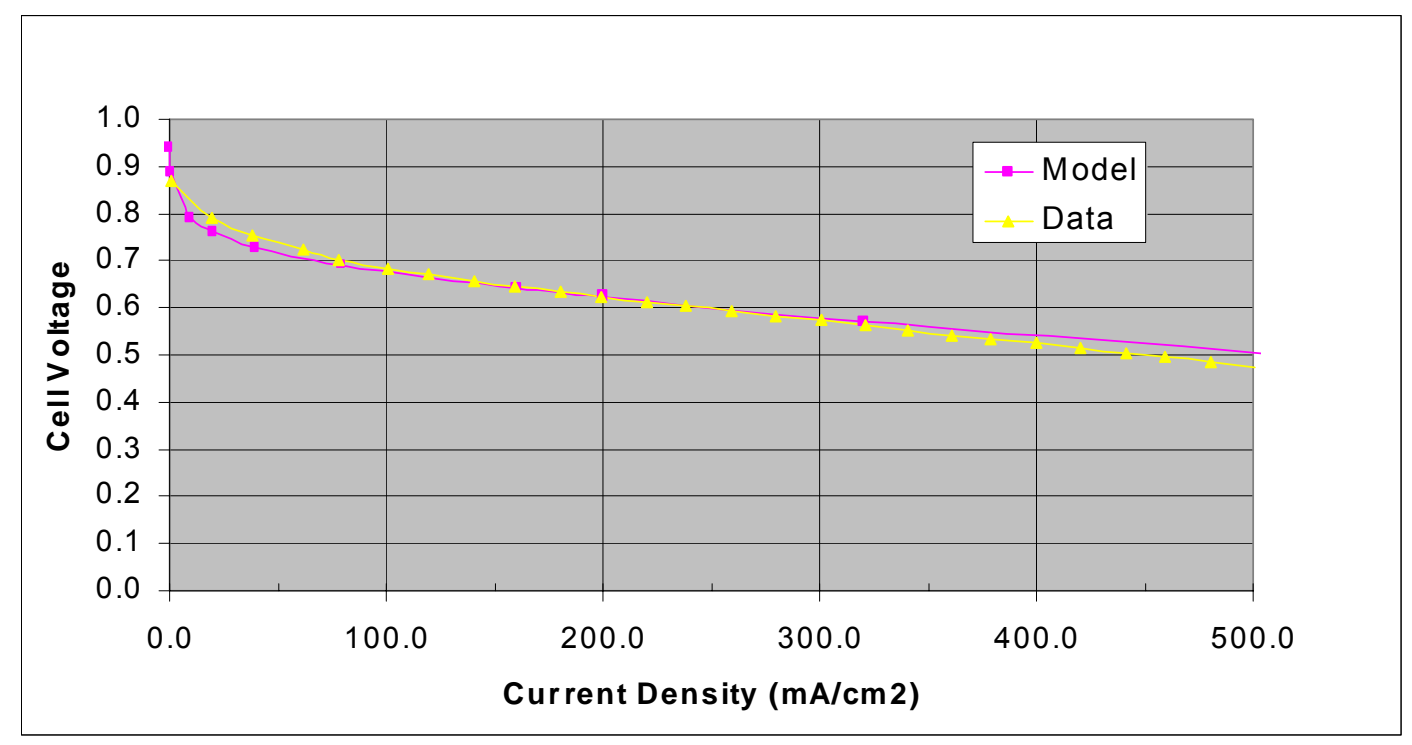

Figure 85: Comparison of Model Prediction and Actual Data

\begin{tabular}{|c|c|}
\hline \multicolumn{2}{|c|}{$\begin{array}{c}\text { Model assumptions, cell data, and cell operating conditions used for } \\
\text { the validation polarization data shown in Figure } 15 .\end{array}$} \\
\hline \multicolumn{2}{|c|}{ Model Assumptions } \\
\hline Catalyst area & $100 \mathrm{~m}^{2} / \mathrm{g}$ \\
\hline Anode polarization & $5 \mathrm{mV}$ per $0.1 \mathrm{~A} / \mathrm{cm}^{2}$ \\
\hline Flow distribution loss & $8 \mathrm{mV}$ per $0.1 \mathrm{~A} / \mathrm{cm}^{2}$ \\
\hline CO loss & $2 \mathrm{mV}$ per $0.1 \mathrm{~A} / \mathrm{cm}^{2}$ \\
\hline \multicolumn{2}{|l|}{ Cell Data } \\
\hline Catalyst utilization & $20 \%$ \\
\hline Cathode loading & $2 \mathrm{mg} / \mathrm{cm}^{2}$ \\
\hline Oxygen gain & $80 \mathrm{mV}$ \\
\hline AC impedance & $2.0 \mathrm{~m}$ at $1 \mathrm{kHz}$ \\
\hline
\end{tabular}




\begin{tabular}{|c|l|}
\hline \multicolumn{2}{|l|}{ Cell operating conditions } \\
\hline Anode stoichs & 1.2 \\
\hline Cathode stoichs & 2.0 \\
\hline Cell temperature & $160^{\circ} \mathrm{C}$ \\
\hline Reformate composition & $\begin{array}{l}49 \% \mathrm{H}_{2} \text { (dry), 2,000 ppm CO } \\
\text { (dry) }\end{array}$ \\
\hline
\end{tabular}

Table 30: Polarization Validation Data

\section{Task 12: Cost Assessment}

A comprehensive cost assessment of PBI-based MEAs was not performed during this program. Due to the variety of manufacturing techniques and materials investigated, it was deemed unreasonable to develop meaningful cost assessments for the overall product.

However, a better understanding of the raw material costs of the MEA components has been established and remain significantly less than that of comparable Nafion-based MEAs.

\section{PROGRAM CONCLUSIONS}

PBI membranes offer the following unique and quantifiable benefits for both automotive and stationary fuel cell power system applications.

- Energy Efficiency - 80\% and higher energy efficiency can be achieved when the PBI fuel cell system operates at temperatures $>120^{\circ} \mathrm{C}$. High temperature facilitates the capture of waste heat and enables true CHP operation. Since fuel cells are capable of converting the chemical energy in the fuel to usable energy at $80+\%$ efficiency in the CHP mode, as compared to $\sim 20 \%$ using heat engines, a highly efficient fuel cell can make better use of the hydrocarbon fuel. As a result, our national dependence on foreign oil (currently greater than $50 \%$ ) is decreased, and national energy security is increased. This benefit will apply to both automotive and stationary applications, when electrical efficiency comparable to or better than low-temperature systems (i.e., as polarization curve values reach those of Nafion) is realized.

- Reliability - Because a PBI membrane operates well without external humidification, the system requires no complex water management. A PBI membrane can tolerate 10,000 ppm of CO at steady-state operation, and over 20,000 ppm CO during transient operation. This combination

of no humidification and high $\mathrm{CO}$ tolerance provides an extremely significant increase in the system reliability, since many fuel cell failures are related to either water management or $\mathrm{CO}$ poisoning. With $\mathrm{PBI}$ membranes, the system can run with very wide operating windows; i.e., 100 to $200^{\circ} \mathrm{C}$, and CO from 10's ppm to 10,000 's ppm. This benefit applies to both transportation and stationary applications.

- Ease of Operation - A PBI fuel cell system, because of its high CO tolerance, can utilize a much simplified fuel processor. The traditional four-stage fuel processor can be 
reduced to only two stages: the autothermal reformer (ATR) and the high-temperature shift (HTS). Typical reformate out of the HTS will contain 5-10,000s ppm of CO, which is well within the tolerance range of the PBI membrane. This benefit applies to both transportation and stationary applications.

- Maintainability and Availability - A PBI fuel cell system is significantly simpler than an equivalent low-temperature or equivalent high-temperature fuel cell requiring complex water management. This is obvious in Figure 3, which compares a Nafionbased fuel cell system with a PBI-based prototype fuel cell system built by Plug. Given this simplicity, system maintenance becomes much easier, and system availability is higher due to the elimination of parts or assemblies. This benefit applies to both transportation and stationary applications.

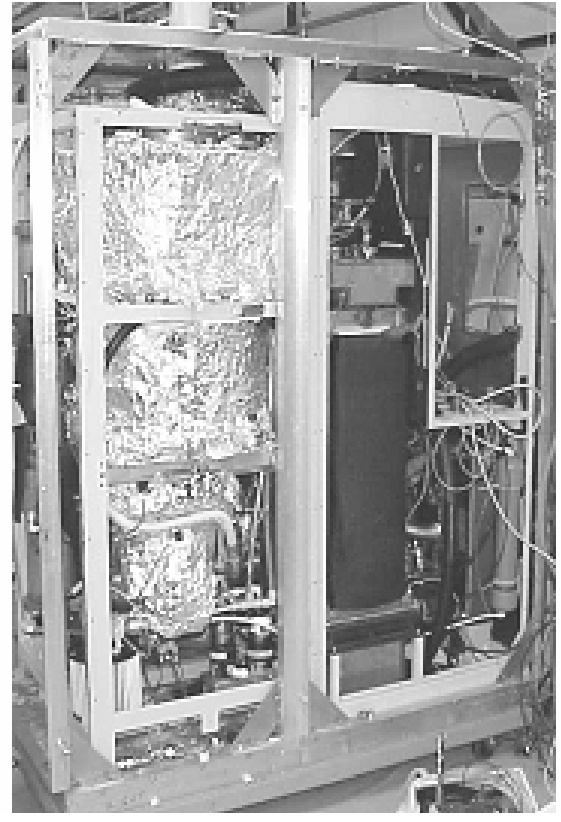

a) Nafion-Based System

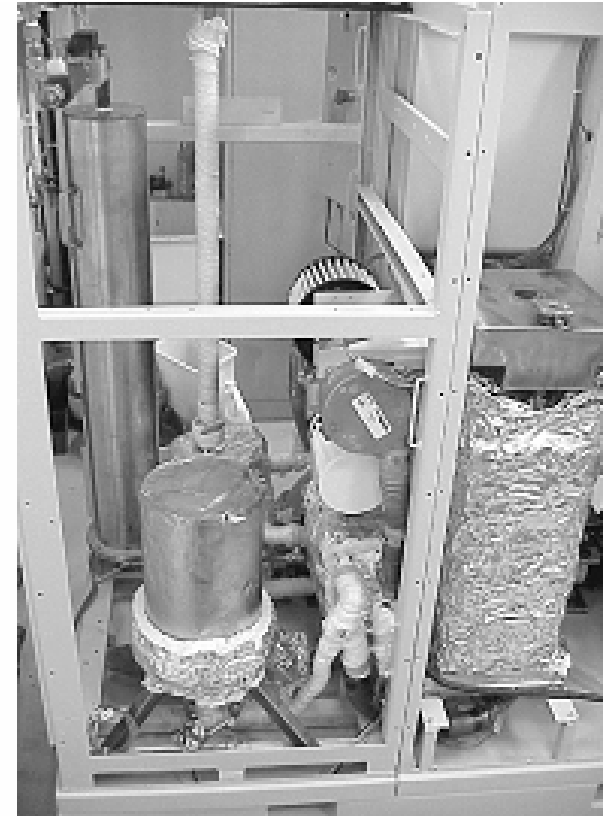

b) PBI-Based System

Figure 86: PBI-Based High-Temperature Fuel Cell versus Equivalent LowTemperature Fuel Cell

- Environmental Benefit - Fuel cells use electrochemical processes to produce power; thus, they generate no particulate emissions and make cleaner, healthier air possible. Pollutants such as $\mathrm{NO}_{x}, \mathrm{SO}_{x}$, and $\mathrm{CO}$ are also significantly reduced with the use of fuel cells. According to the Natural Resources Defense Council, fuel cells produce less than one-four-hundredth of the emissions of nitrogen and sulfur oxides, and one-fifteenth the amount of carbon monoxide per kilowatt than the average utility power generation plant. Fuel cells can play an important role in the battle against the effects of air pollution, which destroy the environment through acid rain and smog, and cause serious health problems, such as asthma and bronchitis. As for $\mathrm{CO}_{2}$ emission, which is considered the leading cause of global warming, a fuel cell emits less than half of the carbon dioxide than does a combustion engine to generate the same amount of electric power. As we 
migrate toward a "hydrogen economy," fuel cells hold promise as perhaps the most efficient way to generate electric power with virtually no harmful emissions - just water, heat, and electricity. This benefit applies to both transportation and stationary applications.

- Economic Benefit - The inherent chemistries and the nature of modular construction make fuel cells a prime distributed generation (DG) technology. Based on data provided by the U.S. DOE, Plug estimates that a total of $59 \mathrm{GW}$ of DG (equivalent to $\$ 59$ billion at $\$ 1000 / \mathrm{kW}$ ) will be added in the United States by 2020. While the size of the fuel cell market has been the subject of many studies (including those sponsored by the government, the fuel cell industry itself, Wall Street analysts, and experienced consultants), most estimates project the stationary fuel cell market at $\$ 6$ billion in 2010 and $\$ 10$ billion by 2020 . Expanding fuel cell applications internationally, DOE estimates a worldwide stationary fuel cell market potential of over $\$ 300$ billion by 2020 . The high energy efficiency and more efficient utilization of higher quality heat will substantially reduce energy consumption.

Complementing and adding to this lucrative stationary fuel cell market is the transportation fuel cell market. The transportation industry is the largest power conversion market in the world. If PEM fuel cells leverage volume and cost reduction to successfully penetrate the transportation market, the transportation fuel cell market will quickly surpass the stationary market and become the primary cost driver. By way of example, a mere 400,000 vehicles, or about $3 \%$ penetration of annual U.S. vehicle volume at $75 \mathrm{~kW}$ per vehicle, will equal to $100 \%$ of the total incremental power generation capacity added annually in the United States (about $30 \mathrm{GW}$ ). The automotive fuel cell market is estimated to be in the $\$ 10$ 's of billions according to Bear Sterns.

- U.S. Competitiveness - The commercialization window for fuel cells is believed to be within the next five years for stationary applications, and, within the next 8-10 years for automotive applications. Plug is racing against stiff competition to become the first to mass-market fuel cell power systems. Having invested \$10's of millions in the development of PBI-based fuel cells in the past four years, Plug leads the world in $\mathrm{PBI}$, high-temperature PEM fuel cell technology development. However, many in the field now recognize the unique value of high-temperature membranes, including PBI membrane, and may pursue this technology with strong focus to compete with Plug. We believe the United States has the competitive edge today worldwide, because Plug is the only company who has built and demonstrated PBI fuel cell systems, and we intend to continue to lead the industry with DOE's support.

- Manufacturing Capability - Team member Celanese is the sole worldwide supplier of PBI materials and, furthermore, the only supplier of PBI-membrane-based MEAs. Celanese has the capability to mass-produce PBI shortly after we identify the best $\mathrm{PBI}$ material for fuel cell membranes. In this program, Celanese does not seek DOE funding for development of the membrane. However, the company has dedicated significant internal funds to support the manufacturing of PBI membranes for fuel cells. Celanese has also committed to fully support the proposed program by providing all the necessary materials and membranes via purchasing agreements. Further, Plug will be demonstrating its ability to design and fabricate systems that will use the PBI membrane. 


\section{PROGRAM-RELATED PATENTS, PUBLICATIONS AND PRESENTATIONS}

\section{Patents}

1. Patent application 11/312938: Fuel cell stack

2. Patent application 11/020636: Fuel cell stack and method for making same

\section{Publications}

1. High Temperature Polybenzimidazoles for Fuel Cell Membranes via a Sol-gel Process. Xiao, L.; Zhang, H.; Scanlon, E.; Ramanathan, L.S.; Choe, E.W.; Rogers, D.; Apple, T.; Benicewicz, B.C. Chem. Mater., 2005

2. Advanced MEA Testing Systems for PEMFC. Gordon Research Conference on Fuel Cells. Bryant University, Smithfield, RI, 7/19/05. D. Giuliano, L. Xiao, B.C. Benicewicz.

\section{Presentations}

1. Synthesis and Evaluation of Poly (2,5-benzoxazole) as a Proton Exchange Membrane Fuel Cell Candidate. ACS Meeting, Chemical Education Division, San Diego, 3/15/05. M. Kienzler, E.W. Choe, E. Scanlon, B.C. Benicewicz.

2. Advanced MEA Testing Systems for PEMFC. Gordon Research Conference on Fuel Cells. Bryant University, Smithfield, RI, 7/19/05. D. Giuliano, L. Xiao, B.C. Benicewicz.

3. Study of Steady-State and Dynamic Long Term Stability of PBI-Based Membranes. Gordon Research Conference on Fuel Cells. Bryant University, Smithfield, RI, 7/19/05. S. Yu, B.C. Benicewicz.

4. High-Temperature Technology Development, 2005 Fuel Cell Seminar, Palm Springs, 11/17/05. R. Staudt 